\title{
AUTOMATIZAÇÃO NA VISUALIZAÇÃO DE ATRIBUTOS DO MEIO FÍSICO UTILIZANDO IMAGENS DIGITAIS
}

\author{
FLÁVIO RODRIGUES CABRERA
}

Dissertação apresentada à Escola Superior de Agricultura "Luiz de Queiroz", Universidade de São Paulo, para obtenção do título de Mestre em Agronomia, Área de Concentração: Máquinas Agrícolas.

P I R A C I C A B A

Estado de São Paulo - Brasil

Setembro - 2004 


\title{
AUTOMATIZAÇÃO NA VISUALIZAÇÃO DE ATRIBUTOS DO MEIO FÍSICO UTILIZANDO IMAGENS DIGITAIS
}

\section{FLÁVIO RODRIGUES CABRERA}

Engenheiro Agrimensor

Orientador: Prof. Dr. JORGE G. G. RAFFO

Dissertação apresentada à Escola Superior de Agricultura "Luiz de Queiroz", Universidade de São Paulo, para obtenção do título de Mestre em Agronomia, Área de Concentração: Máquinas Agrícolas.

\author{
PIR A C I C A B A \\ Estado de São Paulo - Brasil \\ Setembro - 2004
}




\section{Dados Internacionais de Catalogação na Publicação (CIP) DIVISÃO DE BIBLIOTECA E DOCUMENTAÇÃO - ESALQ/USP}

\section{Cabrera, Flávio Rodrigues}

Automatização na visualização de atributos do meio físico utilizando imagens digitais I

Flávio Rodrigues Cabrera. - - Piracicaba, 2004.

84 p. : il.

Dissertação (Mestrado) - - Escola Superior de Agricultura Luiz de Queiroz, 2004.

Bibliografia.

1. Aerofotos 2. Agricultura de precisão 3. Levantamento cartográfico 4. Processamento de imagens 5. Sistema de informação geográfica 6 . Softwares .I. Título

CDD 631.3 


\section{DEDICATÓRIA}

A DEUS pela VIDA e pelas oportunidade de aprendizado.

Aos meus amigos Espirituais pela prática incansável de caridade.

Aos meus pais Ramão Cabrera e Maria de Lourdes Rodrigues Cabrera os quais sempre acreditaram e investiram com carinho e amor em mim.

Aos meus irmãos Liane e Fernando pelo amor e apoio incondicional Aos meus avós Julia Atienza Rodrigues e Valeriana Cabrera.

A minha namorada Michele Marques Ferreira sempre leal, companheira e amiga nas horas mais difíceis.

A meu tio Reinaldo e minha tia Maria Suely pelo grande apoio moral.

Aos meus avós José Feliciano Rodrigues Filho e José Cabrera (in memorian). 


\section{AGRADECIMENTOS}

À Escola Superior de Agricultura "Luiz de Queiroz" - Universidade de São Paulo, pela oportunidade de realização desse curso.

Ao Professor Dr. Jorge Gustavo da Graça Raffo pela amizade, conselhos, críticas, e pela dedicação na realização dessa dissertação.

Aos Professores do Curso de Pós-Graduação em Máquinas Agrícolas: Dr. Casimiro Dias Gadanha Junior, Dr. José Paulo Molin, Dr. Luiz Antonio Balastreire, Dr. Marcos Milan e Dr. Tomaz Caetano Cannavam Ripoli, pelos ensinamentos.

Ao colega e amigo Eng. Agrimensor Márcio Sales Palmeira pela amizade e apoio durante todo o curso e, por incentivar os meus ideais mais elevados.

À Professora Dr. Sonia Maria de Stefano Piedade pela orientação e colaboração na análise estatística dos dados.

Aos técnicos de programação Carlos Roberto de Gois Bertolino e Hamilcar Figueiredo de Miranda pela dedicação na programação do software deste projeto.

Aos funcionários Gilmar Grigolon, Davilmar Collevati, Antônio Gozzo, Hélio Gomes, Sandra Thompson, Osvaldo Rettore, César Rocha, Vanda Zambello, Juarez Amaral e Áureo Oliveira pela cooperação e convívio amigável.

Aos funcionários da Biblioteca pelo pronto atendimento e pelas sugestões na editoração da tese e correções das referências bibliográficas. 
Aos colegas de Curso: Rui, Cezar, Fabiana, Saulo, Murilo, Pincel, Matogrosso, Rodrigo e demais colegas pela amizade e cooperação durante o curso.

Ao amigo Eng. Eduardo Fraga Vieira pelos conselhos, atenção e amizade.

Aos colegas das repúblicas Blue House e Kama Sutra: Pelé, Nei, Raul, Mura, Denis, CPI , Fininho, Morruga, Minimim, Mura, Ricardo, Maicon e demais moradores pelo companherismo.

Aos amigos do Grupo de Samba Chama EU: Saulo, Murilo, Véio, Touche e Sandal, companheiros inseparáveis nos momentos de distração.

As minhas amigas: Dani, Gi e Carole, companheiras de todas as horas.

Enfim, a todos aqueles que, de alguma forma, colaboraram para a realização deste trabalho. 


\section{SUMÁRIO}

Página

LISTA DE FIGURAS ................................................................... ix

LISTA DE TABELAS...........................................................................

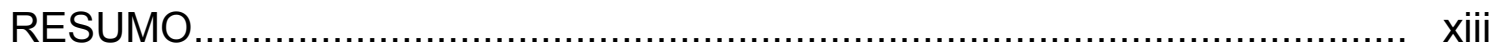

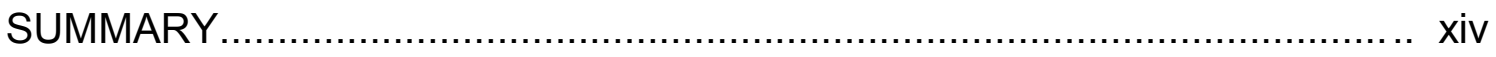

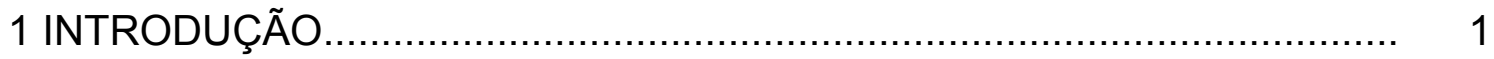

2 REVISÃO DE LITERATURA................................................................ 3

2.1 Agricultura de precisão..............................................................

2.2 Coleta de dados em agricultura de precisão............................................. 5

2.2.1 Método de levantamento de dados................................................. 6

2.2.1.1 Levantamento aerofotográficos................................................... 6

2.2.1.2 Levantamento orbital por sistema de imageamento eletro-óptico..... $\quad 7$

2.3 Processamento de dados e desenho de mapas digitais........................ 9

2.3.1 Modelo numérico do terreno.............................................................. 11

2.3.2 Método de entrada de dados....................................................... 13

2.3.3 Interpoladores e grades................................................................. 15

2.3.4 Elaboração de produtos MNT .................................................... 19

2.3.4.1 Imagens em níveis de cinza....................................................... 19

2.3.4.2 Geração de isolinhas.............................................................. 21

2.3.4.3 Fatiamento do modelo numérico.................................................... 24

2.4 Estrutura das imagens digitais....................................................... 25

2.4.1 Características dos monitores de computador.................................. 27

2.4.2 Representação vetorial e matricial de imagens................................. 28

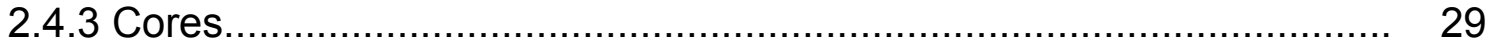


2.4.4 Conversão de dados e de imagens.............................................. 32

2.5 Princípios computacionais............................................................. 40

2.5.1 Fundamentos matemáticos para o algoritmo a ser utilizado............... 40

2.5.2 Fundamentos sobre banco de dados.......................................... 41

2.6 Fundamentos da teoria dos erros................................................ 42

2.7 Análise de regressão linear.............................................................. 43

3 MATERIAL E MÉTODOS .............................................................. 48

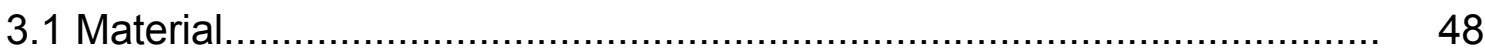

3.1.1 Localização da área de estudo.................................................. 48

3.1.2 Equipamentos utilizados...................................................... 49

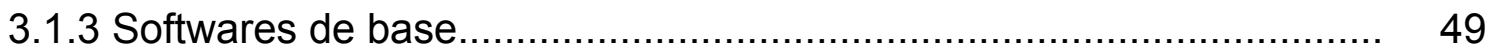

3.1.4 Documentação cartográfica...................................................... 50

3.1.5 Fotografia aérea.............................................................. 50

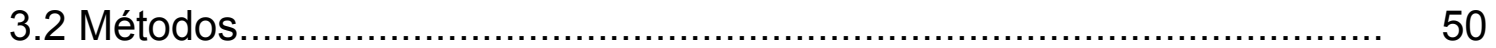

3.2.1 Criação do mapa de fatiamento................................................... 51

3.2.2 Software I, georreferenciamento da fotografia aérea e do mapa de

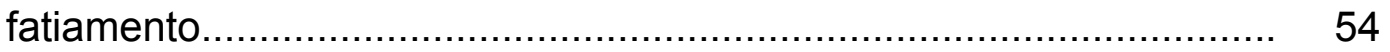

3.2.3 Software II, criação de banco de dados do mapa de fatiamento.......... 56

3.2.4 Software III, vinculação do banco de dados a fotografia aérea............ 65

3.2.5 Teste estatístico, estudo de confiabilidade...................................... 67

4 RESULTADOS E DISCUSSÃO................................................... 69

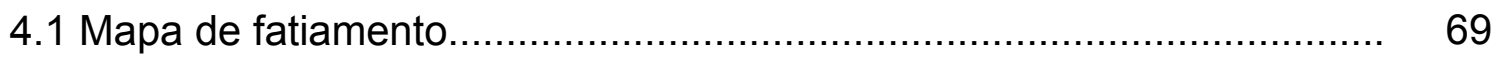

4.1.1 Primeira metodologia, criação do mapa de fatiamento pelo

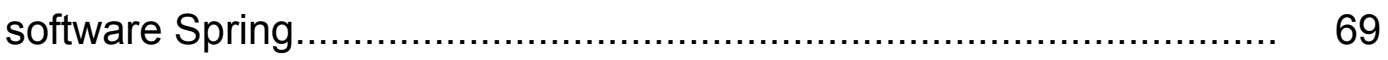

4.1.2 Segunda metodologia, criação do mapa de fatiamento pelo

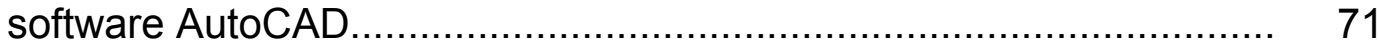

4.2 Resultados da análise estatística e do padrão de exatidão cartográfica. 72

4.2.1 Resultados............................................................................... $\quad 72$

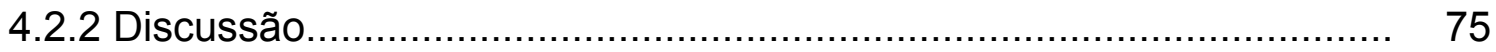

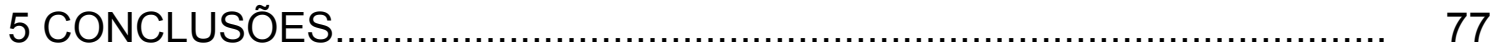




\section{LISTA DE FIGURAS}

Página

1 Ciclo da agricultura de precisão....................................................... 5

2 Vantagens e desvantagens do sistema de imageamento ....................... 9

3 Componentes do SIG.................................................................. 10

4 Métodos de amostragem de pontos................................................ 14

5 Modelo de superfície gerada por grade regular..................................... 15

6 Modelo de superfície gerada por grade irregular................................... 16

7 Interpolação por vizinho mais próximo...................................................... 17

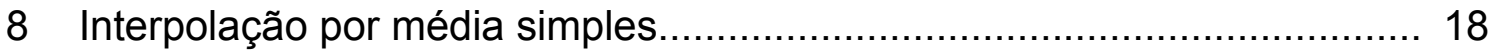

9 Interpolador por média ponderada por quadrante …........................... 19

10 Interpolador por média ponderada por cota e quadrante......................... 19

11 Mapeamento dos valores de atributos para um valor de níveis de cinza... 20

12 Imagem em níveis de cinza com curvas de nível sobreposta.................... 21

13 Geração de isolinhas a partir do modelo de grade retangular.................. 21

14 Geração de isolinhas a partir do modelo de grade triangular .................. 22

15 Isolinha com pequena resolução.............................................................. 23

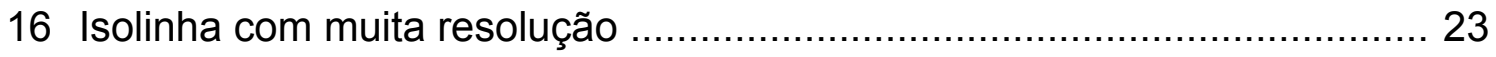

17 Comportamento de isolinhas pela função B-Spline ..................................... 24

18 Ilustração do processo de fatiamento do MNT .......................................... 24

19 Mapa de fatiamento gerado por um MNT ............................................. 25

20 Exemplo de uma imagem (cruz), em que, sue formato digital é representado por uma matriz numérica................................................. 26

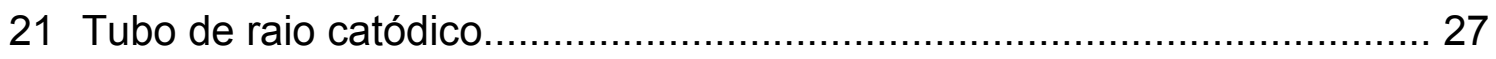


22 Representação de matriz.......................................................... 28

23 Processo aditivo das cores primárias................................................. 30

24 Processo subtrativo das cores secundárias........................................... 31

25 Processo de obtenção das cores secundárias....................................... 32

26 Operação de georreferenciamento................................................... 34

27 Relação projetiva entre fotografia e terreno ou mapa.............................. 34

28 Relação entre objeto e imagem com sistemas de eixos paralelos............. 35

29 Relação entre sistemas de coordenadas da fotografia e do terreno.......... 37

30 Ângulo de atitude do avião................................................................. 38

31 Exemplo de estrutura de banco de dados........................................ 41

32 Diagrama de dispersão................................................................... 44

33 Reta de tendência dos pontos amostrais............................................. 46

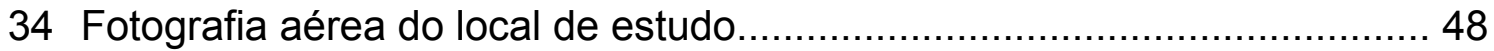

35 Método de digitalização de curvas de nível com pouca curvatura.............. 52

36 Método de digitalização de curvas de nível com muita curvatura............... 52

37 Exemplo de mapa de fatiamento produzido pelo software Spring .............. 53

38 Parte do mapa de fatiamento produzido pelo software AutoCAD ............... 54

39 Representação dos pontos de controle na fotografia aérea...................... 55

40 Coordenadas dos pontos de controle.................................................. 55

41 Representação do processo de cálculo das coordenadas do ponto $\mathrm{P}$ no sistema de coordenadas da imagem........................................... 56

42 Origem do processo de varredura de cores dos pixels da imagem........... 57

43 Representação do algoritmo de varredura de cores................................ 57

44 Visualização da faixa de cor de varredura da situação I.................................. 58

45 Visualização das faixas de cores de varredura pela situação II..................... 60

46 Visualização das faixas de cores de varredura pela situação III................... 61

47 Visão frontal de uma região de vale..................................................... 61

48 Visão frontal de uma região de cristas.................................................... 62

49 Visualização da faixa de cor de varredura da situação IV .......................... 63

50 Representação da vinculação do banco de dados a fotografia aérea....... 65 


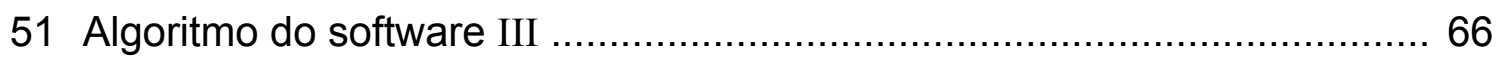

52 Mapa de fatiamento produzido pelo método híbrido ................................ 69

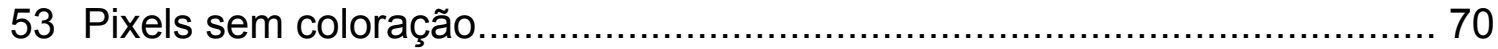

54 Fatias de cores não seguindo a distribuição das curvas de nível............... 70

55 Parte do mapa de fatiamento produzido pelo software AutoCAD ............... 71

56 Distribuição dos pontos de controle de análise na carta topográfica........... 72

57 Diagrama de dispersão dos dados analisados.......................................... 75 


\section{LISTA DE TABELAS}

Página

1 Coordenadas $Z$ nos pontos de controle de análise para comparação.......... 72

2 Resultados estatísticos para os pontos de análise..................................... 74

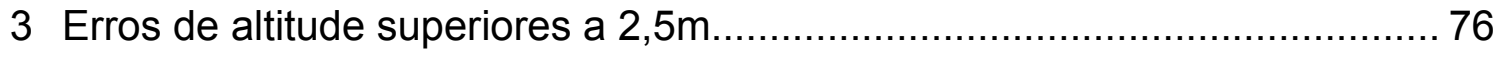




\title{
AUTOMATIZAÇÃO NA VISUALIZAÇÃO DE ATRIBUTOS DO MEIO FÍSICO UTILIZANDO IMAGENS DIGITAIS
}

\author{
Autor: FLÁVIO RODRIGUES CABRERA \\ Orientador: Prof. Dr. JORGE G.G. RAFFO
}

\section{RESUMO}

O presente trabalho de pesquisa apresenta uma metodologia de implantação de isolinhas em imagens digitais. Para isso foi desenvolvido um software que vincula a imagem digital ao mapa de isolinhas georreferenciado, permitindo recuperar uma variável espacialmente distribuída, altitude, produtividade, fertilidade do solo, etc, a partir da indicação de um ponto sobre uma fotografia aérea oriunda de câmara digital ou uma imagem de satélite. As referidas imagens são rasterizadas, através do uso de scanner e, posteriormente, georreferenciadas pelo método das equações de colinearidade entre superfícies planas. Como resultado deste processamento, podem ser obtidas as coordenadas UTM da imagem e o valor da variável em estudo. A facilidade operacional da metodotologia, assim como, seus menores custos em relação aos métodos tradicionais de modelagem poderão contribuir significativamente para os projetos agrícolas que requerem uso de imagens georreferenciadas e obtenção de valores de parâmetros do campo. 


\title{
AUTOMATION IN VIEWINGS OF ATTRIBUTES OF THE PHYSICAL MIDDLE USING DIGITAL IMAGES
}

\author{
Author: FLÁVIO RODRIGUES CABRERA \\ Adviser: Prof. Dr. JORGE G.G. RAFFO
}

\section{SUMMARY}

The current research work presents a digital methodology of implantation of isolines in images. With this objective a software was developed to tie a digital image with a map of geo-referenced isolines. Allowing to recoup an variable space distributed, as altitude, productivity, fertility and others parameters, from the indication of a point on a deriving air photograph of digital camera or an satellite image. The related images are record digitally through the use of scanner and geo-referenced for the method of the colinearity equations between plain surfaces. As result of this processing, coordinates UTM of the image and the value of the variable in study can be gotten. The operational easiness of the methodology, as well as its lesser costs with relation to the traditional methods will be able to contribute significantly with the activities of agricultural that require the use of geo-referenced images and the attainment of field parameters values. 


\section{INTRODUÇÃO}

O Brasil já é uma das potências agrícolas do mundo em função da grande quantidade de terras de boa qualidade para a agricultura, da abundância de água existente na maioria do país, do clima tropical e da grande incidência de luz durante todo ano. Mas, para poder ser competitivo nesta área do comercio mundial, em que os concorrentes são países do primeiro mundo, os quais operam com as mais avançadas tecnologias e, além disso, com subsídios agrícolas, é necessário aplicar todos os avanços tecnológicos em nosso sistema produtivo além da adoção de uma série de medidas comerciais em defesa da Agricultura. Os avanços tecnológicos incluem desde o melhoramento genético através de técnicas de Biotecnologia até o manejo em forma pontual dos insumos agrícolas utilizando técnicas de Agricultura de Precisão, e passando por uma mecanização acelerada de nosso campo com um controle mais efetivo de pragas sem prejudicar o meio ambiente. Devido a toda esta evolução tecnológica, já existe uma conscientização dos produtores, da necessidade de administrar as propriedades rurais como verdadeiras empresas em que se deve procurar a otimização do uso de recursos produtivos.

É de grande importância que o planejador conte com um conjunto de informações gráficas da propriedade no momento da tomada de decisão, para escolher a melhor forma de manejo. Esses recursos gráficos eram visualizados antigamente sobre os mapas-papel da propriedade. Hoje, existem recursos muito mais sofisticados como imagens de satélite, fotografias aéreas em formato digital, associado ao uso de receptores GPS e principalmente ao Sistema de Informação Geográfica (SIG). 
Os Sistemas de Informação Geográfica existentes no mercado possibilitam visualizar imagens, fotografias, mapas topográficos e temáticos diversos, como tipo de solos, curvas de nível, hidrografia, produtividade, lucratividade de cada região da propriedade etc, assim como, permitir o cruzamento das diversas informações e efetuar uma análise espacial detalhada.

Estes softwares exigem um aprofundado conhecimento de seu uso por parte das pessoas que os utilizam, obrigando muitas vezes às empresas a contratar técnicos especializados em geoprocessamento para operar estes sistemas. Na prática constata-se que esta situação muitas vezes inviabiliza o uso destes importantes recursos tecnológicos por parte do produtor rural.

Com objetivo de providenciar um produto que apresentasse algumas características similares a um SIG, mas que fosse de fácil uso por parte do produtor rural é que foi desenvolvida esta pesquisa. A mesma, consiste na implementação de uma metodologia onde o resultado final consta de uma imagem ou fotografia digital vinculada a um Banco de Dados que fornece informação qualitativa ou quantitativa referente a cada pixel da imagem. No exemplo utilizado para desenvolver e testar a metodologia, utilizou-se uma fotografia aérea digital e um mapa de curvas de nível do terreno como fonte das informações a serem incorporadas no banco de dados. Neste caso, o software , desenvolvido, fornece altitude de pontos, mas nada impede que as isolinhas sejam de outro tipo, como por exemplo curvas de igual produtividade do terreno. E nesse caso o software fornecerá a produtividade em cada ponto da imagem.

Buscando facilitar mais a vida do administrador rural, desenvolveu-se o produto em linguagem de programação Java, para que pudesse ser visualizado através da Internet. Dessa forma, torna-se possível efetuar consultas e discussões do produtor com seus assessores técnicos sem necessidade de ter que efetuar reuniões presenciais. Acredita-se que o produto desenvolvido vai contribuir eficazmente com as tarefas de planejamento e de manejo de uma empresa agropecuária moderna. 


\section{REVISÃO DE LITERATURA}

Perante um mercado competitivo e com consumidores mais exigentes, presenciam-se profundas transformações na agricultura brasileira. Novas tecnologias foram adaptadas ao meio agrícola proporcionando um melhor gerenciamento. Exemplo disso são os Sistemas de Posicionamento por Satélites Artificiais ${ }^{1}$ e o Sistema de Informação Geográfica ${ }^{2}$, tecnologias estas, respectivamente utilizadas na agricultura como base para a geração de mapas de produtividade, de isolinhas, de componentes químicos ou físicos do solo, entre outros.

Isso tudo pode ainda causar certo espanto para muitos. No entanto, o que parecia uma concepção meio "de outro mundo", aplicada à agricultura, já esta se tornando realidade e começa atingir e influenciar a rotina das propriedades agrícolas (Molin, 2001).

\subsection{Agricultura de precisão}

Agricultura de precisão é um conjunto de tecnologias e procedimentos gerenciais utilizados para que as lavouras e o sistema de produção sejam otimizados, tendo como elemento chave o gerenciamento da variabilidade espacial da produção e dos fatores a ela relacionados. Ela se baseia na medição do rendimento, determinação das condições do solo e da cultura, estudo da topografia e de outras informações de cada parte do campo,

\footnotetext{
${ }^{1}$ Sistemas utilizado para coletar informações de posicionamento de um atributo no espaço tridimensional.

${ }^{2}$ Ferramenta utilizada para tratamento de informações do meio físico.
} 
associando-os a localização espacial. Uma vez georreferenciadas, estas informações podem ser expressas na forma de mapas digitais. As informações contidas nestes mapas permitem aos técnicos chegar às variações espaciais $\mathrm{e}$ temporais dos fatores limitantes da produção, orientando-os no processo de tomada de decisão na aplicação localizada de insumos e no manejo diferenciado das culturas nos campos de produção. A origem da agricultura de precisão, como é concebida hoje, tem suas raízes na pressão por uma agricultura menos agressiva ao meio ambiente. A necessidade da dosagem de insumos que permitam maximizar a produção sem que potenciais excedentes de fertilizantes e defensivos comprometam a qualidade, especialmente da água, foi o fator principal para o desenvolvimento da tecnologia (Molin, 2001).

Segundo Rocha (2001), a agricultura de precisão compreende o uso das chamadas geotecnologias: sistema de localização por satélite, sistemas informatizados de coleta de dados, sensores remotos orbitais e não orbitais, softwares para tratamento e mapeamento de informações espaciais (Sistema de Informação Geográfica - SIG) e sistemas eletrônicos de acionamento e controle de máquinas agrícolas.

Com informações da variabilidade da produtividade em mãos, tornase necessário buscar as causas da variabilidade, que podem ser as mais diversas. Normalmente, parte-se para a investigação da fertilidade do solo através de amostragem programada e criteriosa. Faz-se um acompanhamento da lavoura buscando explicações para cada possível mancha, tanto de alta com de baixa produtividade. Quando se tem segurança dos fatores causadores de diferenças na produtividade, parte-se para a última etapa do processo de agricultura de precisão, que é o tratamento localizado dos fatores considerados como culpados (Molin, 2001).

Esse, em síntese, é o ciclo operacional da agricultura de precisão (Figura 1). No entanto, para chegar a esse ponto, o agricultor terá percorrido um longo caminho de coleta de informação, interpretação e diagnóstico. Todas essas informações, a começar pelos mapas de produtividade e passando pelos 
mapas de fertilidade, modelos numéricos do terreno, ocorrências na lavoura e muito mais, é de uma riqueza de detalhes fantástica e ao mesmo tempo complexa.

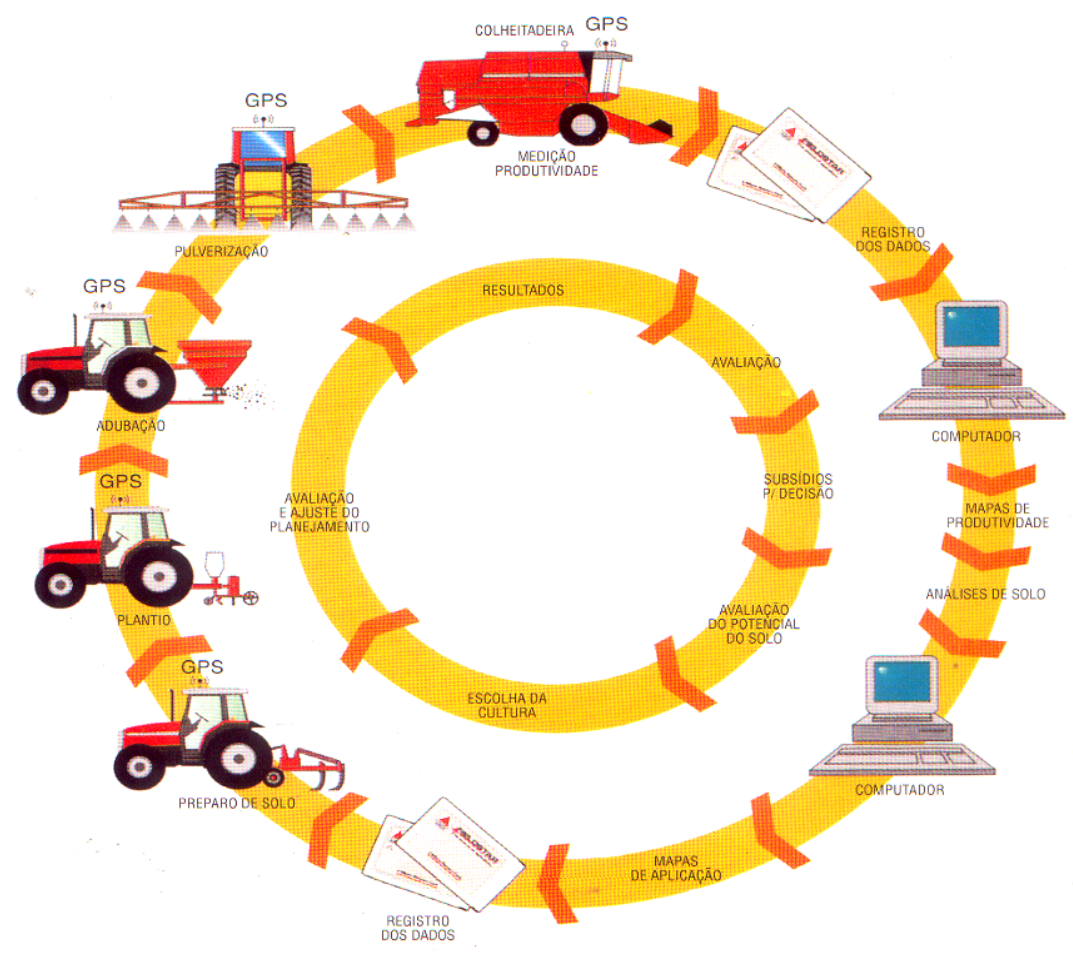

Figura 1 - Ciclo da agricultura de precisão (Cabrera, 2002)

\subsection{Coleta de dados em Agricultura de Precisão}

A idéia de que o agricultor possa identificar os locais de alta e baixa produtividade de cada talhão e depois vir a administrar essas diferenças, somente é possível com uma grande quantidade de informações coletadas em campo durante um longo período. Todas essas informações são adquiridas, na maioria das vezes, por tecnologias adotadas de outras áreas, muitas delas bastante distantes da agricultura. Exemplo disso seria o uso de computadores, softwares específicos e muitos sensores e controladores utilizados nas máquinas agrícolas (Molin, 2001). Os informes adquiridos como: produtividade, 
componentes de fertilidade do solo, ocorrência de plantas daninhas, doenças, entre outras, são georreferenciadas através do uso do GPS (Global Positioning System). Esse equipamento fornece o posicionamento das informações adquiridas em campo. Esse conjunto de dados passa a ser o centro de todo o gerenciamento da propriedade.

\subsubsection{Método de levantamento de dados}

As atividades relacionadas à Agricultura de Precisão compõem um ciclo fechado de tarefas. De qualquer maneira, todo o processo dever ter um ponto de partida (Molin, 2001). Muitos pesquisadores e usuários têm como uma verdade já consagrada que o mapa de produtividade é a informação mais completa para se visualizar a variabilidade espacial das lavouras.

Balastreire (1998) e Pecze et al. (1999) consideram que a geração de mapas de produtividade é a fase que apresenta maior facilidade de execução devido ao número de pesquisas já realizadas nos países mais desenvolvidos e opções de equipamentos existentes, principalmente para culturas de cereais.

Várias outras ferramentas têm sido propostas para se identificar às manchas existentes em um talhão. É assim que as fotografias aéreas, imagens de satélite, videografia, condutividade elétrica do solo e outras, têm sido utilizadas (Molin, 2001).

\subsubsection{Levantamento aerofotográfico}

É o tipo mais comum de missão de sensoriamento remoto em nível suborbital, é realizado por aeronaves.

As fotografias aéreas apresentam forma de registro contínuo, significa que a informação é registrada com um sinal contínuo que representa a exposição sobre a cena observada por um sensor fotográfico, cujo produto final apresentado para análise são dados analógicos, como as imagens em cópias 
de papel ou transparências. Segundo o Manual of Photogrammetry (1980) chama-se foto vertical à fotografia aérea, tomada de forma que o eixo ótico da câmara coincida com a vertical. A vertical é a linha definida pela força da gravidade em cada ponto da Terra e materializada pelo fio de prumo. O modelo matemático básico da Fotogrametria é desenvolvido a partir da hipótese de que o eixo ótico da câmara é perpendicular ao plano objeto e ao plano imagem.

Uma fotografia, embora sendo do tipo vertical, dificilmente terá uma escala constante, como conseqüência das diferentes altitudes dos pontos do terreno. Muitas vezes, o usuário da fotografia precisa conhecer um valor, mesmo que aproximado, da escala da imagem e, com este objetivo, definir a escala média. Este valor é o resultado da média de várias escalas em diferentes regiões da fotografia. A escala média é conhecida normalmente pelos usuários como "escala da foto" e, geralmente, aparece indicada num dos cantos nas fotografias aéreas obtidas com câmara métrica (Raffo, 2000).

\subsubsection{Levantamento orbital por sistemas de imageamento eletro-óptico}

Em levantamentos orbitais considera-se a aquisição de dados espectrais utilizando sistemas de imageamento eletro-óptico, equipados com sensores colocados a bordo de satélites artificiais.

Os sistemas de imageamento eletro-óptico diferem dos sistemas fotográficos, porque os dados são registrados em forma de sinal elétrico, o que possibilita sua transmissão à distância. Esta forma de registro é conhecida como forma discreta. Diferente da fotografia aérea, formato contínuo, os detalhes são mantidos em unidades digitais ou discretas, que não podem ser vistas, mas podem ser tratadas e manipuladas quantitativamente. $O$ conjunto de técnicas e procedimentos utilizados para processar essas informações, com a finalidade de torná-las adequadas à interpretação, é conhecido como "processamento digital de imagens" (Novo, 1993). 
Segundo Novo (1993), o sistema de imageamento eletro-óptico é classificado em três grandes grupos quanto ao processo de formação de imagens: sensores de quadro (frame), sensores de varredura mecânica e sensores de varredura eletrônica.

Os sensores de quadro ou "frame" são também conhecidos por vidicons e tiveram origem a partir do sistema de televisão. Esse tipo de imageador é composto por um tubo fotossensível com um sistema de varredura por feixe de elétrons (Novo, 1993).

Segundo Moreira (2001), os sensores de varredura mecânica são basicamente constituídos por um conjunto de espelhos giratórios ou prismas, para coletar a radiação eletromagnética proveniente dos alvos da superfície imageada; um sistema óptico, capaz de focar a energia coletada sobre detetores, que a convertem em um sinal elétrico. Esse sistema vem sendo utilizado pelos sensores MSS e TM a bordo dos satélites da série Landsat.

Os sensores de varredura eletrônicos utilizam um sistema óptico grande-angular, através do qual a cena é imageada em sua totalidade através de um arranjo linear de detectores. O sinal de cada detector é amplificado separadamente e o sinal de saída é amostrado seqüencialmente, formando uma linha de pontos amostrados no terreno. À medida que a plataforma se locomove ao longo da órbita, sucessivas linhas são imageadas no terreno pelo arranjo linear de detectores, amostradas e transmitidas. Este sistema é utilizado no programa espacial SPOT (Novo, 1993).

A Figura 2 resume as principais vantagens e desvantagens dos três principais sistemas de imageamento eletro-óptico. 


\begin{tabular}{|c|c|c|c|}
\hline Sistema & Vidicon & $\begin{array}{l}\text { Varredura } \\
\text { Eletrônica }\end{array}$ & $\begin{array}{l}\text { Varredura } \\
\text { Mecānica }\end{array}$ \\
\hline Vantagens & $\begin{array}{l}\text { Possibilidade de } \\
\text { transmissão } \\
\text {-Utilizāvel em Sis } \\
\text { temas de longa dú } \\
\text { racão }\end{array}$ & $\begin{array}{l}\text {-Geometria mais es } \\
\text { tável } \\
\text {-Transmissão } \\
\text {-Utilizāvel em mis } \\
\text { sōes de longa du } \\
\text { racão }\end{array}$ & $\begin{array}{l}\text { - Alta resolucão es } \\
\text { pectral } \\
\text { Possibilidade de } \\
\text { transmissão } \\
\text { - Utilizāvel em sis } \\
\text { temas de longa du } \\
\text { racão }\end{array}$ \\
\hline Desvantagens & $\begin{array}{l}\text { - Sensibilidade } \\
\text { - Geometria instāvel } \\
\text { em duas dimensōes } \\
\text { - Resolucão espacial } \\
\text { limitada }\end{array}$ & $\begin{array}{l}\text { - Resolucão espacial } \\
\text { limitada pela taxa } \\
\text { de transmissão de } \\
\text { dados }\end{array}$ & $\begin{array}{l}\text { - Resolucão espacial } \\
\text { limitada } \\
\text { Instabilidade geoo } \\
\text { mētrica em } 1 \text { dimen } \\
\text { sāo }\end{array}$ \\
\hline
\end{tabular}

Figura 2 - Vantagens e desvantagens do sistema de imageamento eletro-ópticos (Novo, 1993)

Analisando a Figura 2, observa-se que todos os sistemas de imageamento eletro-ópticos possuem a vantagem de poderem transformar a energia que chega do alvo em sinais elétricos transmissíveis a grandes distâncias. Esta vantagem torna esses sistemas particularmente úteis aos programas espaciais de sensoriamento remoto.

\subsection{Processamento de dados e desenho de mapas digitais}

O processamento, análise, modelagem e produção de mapas de dados espaciais é executado pelo Sistema de Informação Geográfica - SIG.

Segundo Rocha (2001), Sistema de Informação Geográfica é um sistema que engloba software, procedimentos e módulos, ou subsistemas, integrados e projetados para dar suporte ao armazenamento, processamento, análise, modelagem e exibição de dados e/ou informações espacialmente referenciadas, constituídas numa única base de dados.

Qualquer sistema de informação geográfica apresenta duas características principais. Permite inserir e integrar, numa única base de dados (banco de dados), informações espaciais provenientes de diversas fontes tais como, cartografia, imagem de satélites, dados censitários, dados de cadastro 
rural e urbano, dados de redes e de modelo numérico do terreno e oferece mecanismo para combinar várias informações através de algoritmos de manipulação e análise, bem como de consulta, recuperação, visualização e plotagem do conteúdo dessa base de dados georreferenciados (INSTITUTO NACIONAL DE PESQUISAS ESPACIAIS - INPE, 1995).

Numa visão abrangente, pode-se dizer que um SIG é composto de cinco componentes independentes, porém interligados uns aos outros, através de funções específicas (Câmara et al., 1996). Os componentes do SIG são (Figura 3):

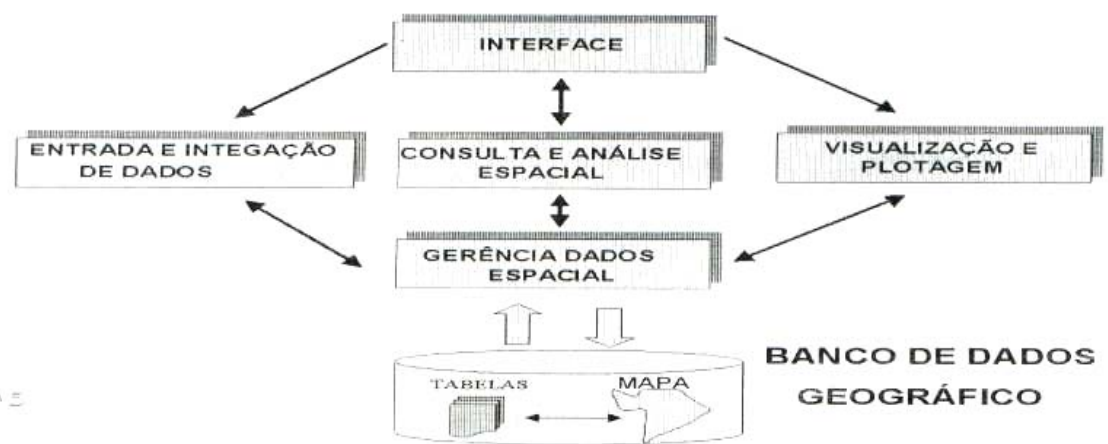

Figura 3 - Componentes do SIG (Câmara et al., 1996)

- Entrada e integração de dados: refere-se a todos os aspectos de aquisição de dados espaciais, contidos em mapas, fotografias aéreas, imagens de satélites, dados de campo, dados digitalizados, entre outros (Moreira, 2001).

- Interface: constitui-se de um conjunto de funções que serve como suporte de entrada e integração dos dados. As funções relacionadas à interface são acionadas através de menus (Câmara et al., 1996).

- Consulta e análise espacial: aqui estão envolvidos todos os softwares de tratamento dos dados, e consiste de algoritmos que realizam operações de pré-processamento, de classificação e de pós-processamento (Moreira, 2001). 
- Visualização e plotagem: serve para visualizar e plotar os dados quer sejam espaciais ou alfanuméricos. Para auxiliar nesta tarefa empregam-se monitores de vídeo, impressoras e plotters (Moreira, 2001).

- Banco de dados geográfico: conjunto de arquivos espaciais, georreferenciados, estruturados de forma a facilitar o acesso a determinadas informações que descrevem determinadas entidades do mundo real (Moreira, 2001).

A integração de modelos ambientais e SIG é um vasto e crescente campo para cientistas ligados ao geoprocessamento, meio ambiente e agricultura.

Após a expansão de pesquisas baseadas em SIG no final da década de 80 , é evidente o desenvolvimento de uma nova onda de interesse em SIG pelas ciências do meio ambiente (ex: ecologia, biologia, hidrologia), agricultura (agricultura de precisão e planejamento de uso da terra), dado o número de pesquisadores envolvidos na integração de modelos ligando a agricultura e o meio ambiente à tecnologia SIG (Bacellar,1994; Carver et al, 1995 e Shirmohammadi et al, 1994).

Num SIG, dados de variabilidade espacial de rendimento de cultura podem ser analisados conjuntamente como outros dados (Ex: fertilidade do solo, altitude) para se modelar cenários futuros e se avaliar a efetividade de manejo, monitorado para cada área (Peccol et al., 1994). Isto somente é possível, com o uso das técnicas de modelagem numérica do terreno, proporcionado assim, melhores condições de análise para os tomadores de decisões, como produtores, consultores e prestadores de serviço (Rocha, 2001).

\subsubsection{Modelo numérico do terreno}

Modelo numérico do terreno (MNT) é uma representação matemática da distribuição espacial de um atributo espacial (grandeza medida dentro de 
uma região da superfície terrestre). A grandeza é, em geral, contínua e o fenômeno por ela representado pode ser variado. Assim, pode-se ter modelos de temperatura, de altimetria, de dados geoquímicos e geofísicos etc. O modelo numérico é gerado a partir de um conjunto de pontos $\left(X_{i}, Y_{i}, Z_{i}, i=1,2,3, \ldots n\right)$ amostrados da superfície real, sendo que as coordenadas $X$ e $Y$ dos pontos estão relacionadas às posições de amostragem na superfície, e a coordenada $Z$ está relacionada à característica que se quer modelar (Assad \& Sano, 1993).

As características associadas às superfícies podem ser de natureza diversa. Os modelos numéricos são utilizados para se obter informações relevantes da superfície sem a necessidade de se trabalhar diretamente nela. Essas informações podem ser de caráter qualitativo (visualização da superfície através de uma projeção geométrica) ou quantitativo, englobando cálculo de áreas, volumes e isolinhas, entre outros (INPE, 2001).

Assad \& Sano (1993), estudaram a ocorrência de veranicos (período de interrupção da precipitação que ocorrem durante a estação chuvosa) do cerrado, estabelecendo uma interface entre a análise estatística detalhada e os MNT, manipulados num sistema de informações geográficas.

Moraes et al. (2001), obtiveram um MNT a partir de dados de um receptor GPS, com correção diferencial. Para geração do modelo utilizaram o método de krigagem. A metodologia mostrou-se precisa e rápida para obtenção de dados altimétricos para utilização em agricultura de precisão.

Steinmetz et al. (1985), procuram identificar, para o Estado de Goiás, as melhores datas de plantio para o arroz de sequeiro utilizando MNT. O resultado final foi à elaboração de mapas do Estado de Goiás mostrando áreas que são favoráveis, intermediárias, desfavoráveis e altamente desfavoráveis para o arroz de sequeiro, conforme as datas de plantio, as variedades de arroz e os tipos de solos pré-selecionados.

No processo de MNT pode-se distinguir três fases: a aquisição dos dados (através de importação ou edição de dados), a geração de modelos de grades e a elaboração de produtos. A aquisição destes dados é geralmente 
realizada por levantamentos de campo, por digitalização de mapas, por medidas fotogramétricas a partir de modelos estereoscópicos etc (INPE, 2001).

Entretanto as aplicações, ou produtos de MNT, não são elaborados sobre os dados amostrados, mas sim, a partir dos modelos gerados no formato de grade regular ou irregular. Estes formatos simplificam a implementação dos algoritmos de aplicação e os tornam mais rápidos computacionalmente.

\subsubsection{Método de entrada de dados}

Os métodos de aquisição de dados podem ser por digitalização de mapas de isolinhas e por amostragem de pontos com espaçamento irregular e regular.

a) mapas de isolinhas: um mapa de isolinhas nada mais é do que a representação de uma superfície por meio de curvas de isovalor (ex: curvas de nível, iso-produtividade). Segundo Molin (2000), é muito comum à representação de mapas de produtividade por isolinhas que delimitam regiões com produtividade dentro de um mesmo intervalo. A digitalização de isolinhas pode ser efetuada por meio de uma mesa digitalizadora, por tela de computador, semi-automática e automática. Cintra \& Nero, apresentaram resultados de um estudo que comparou as formas de digitalização (em mesa digitalizadora, em tela, semi-automática e automática), precisão e tempo de digitalização obtida de uma carta topográfica na escala 1:50.000. Para prosseguir na comparação e apontar algumas recomendações práticas, o autor salientou que é útil caracterizar diferentes situações em que o usuário pode se encontrar, em termos de material disponível. Quando se dispõe de mapa de papel, a digitalização em mesa, em comparação com a em tela, mostra-se vantajosa em função do menor tempo de digitalização e de não precisar escanear o mapa. Já a digitalização em tela tem as vantagens de uma maior precisão e implica em um único processo de georreferênciamento. Quando se dispõe de fotolitos não faz sentido efetuar digitalização através dos métodos em 
mesa e em tela, que não tem melhor precisão e são mais demorados. 0 método automático é significativamente melhor que o semi-automático na digitalização de isolinhas (Cintra \& Nero, 2001).

b) amostragem por pontos: de acordo com o tipo de aquisição tem-se a distribuição das amostras conforme apresenta a Figura 4. O cuidado na escolha dos pontos e a quantidade de dados amostrados estão diretamente relacionados com a qualidade do produto final de uma aplicação sobre o modelo. A amostragem não deve ser aleatória. Para aplicações onde se requer um grau maior de acurácia, as amostras devem estar bem distribuídas. Deve-se ter densidades altas de amostras nas regiões mais erráticas, ou seja, de grande variabilidade do atributo. Por outro lado, densidades altas em regiões homogêneas, com pouca variabilidade do atributo, podem ser redundantes e aumentar, desnecessariamente, o esforço computacional para armazenagem e processamento das amostras (INPE, 2001).

Totalmente Irregular

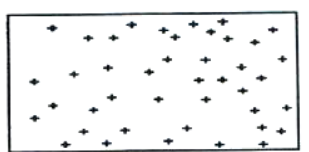

Aerolevantamento

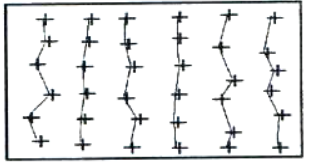

A partir da Drenagem

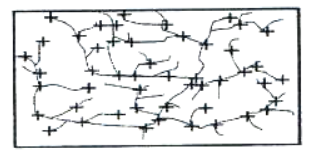

Regular

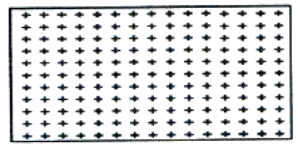

Figura 4 - Métodos de amostragem de pontos (INPE, 2001) 


\subsubsection{Interpoladores e grades}

No processo de modelagem utilizam-se os interpoladores, que são procedimentos de estimação de valores de um atributo em locais não amostrados a partir de pontos amostrados na mesma área ou região (Sameshima \& Yamamoto, 1996).

A modelagem por grade regular (Figura 5) é um modelo digital que aproxima superfícies através de um poliedro de faces retangulares. A geração de grade regular é efetuada quando os dados amostrados na superfície não são obtidos com espaçamento regular. Assim, a partir das informações contidas nas isolinhas ou nos pontos amostrados, gera-se uma grade que representa, da maneira mais fiel possível, a superfície. O espaçamento da grade deve ser idealmente menor ou igual a menor distância entre duas amostras com valores diferentes. Ao se gerar uma grade muito fina (densa), ou seja, com distância entre os pontos muito pequena, exigirá um maior número de informações sobre a superfície analisada necessitando maior tempo para sua geração (INPE, 2001).

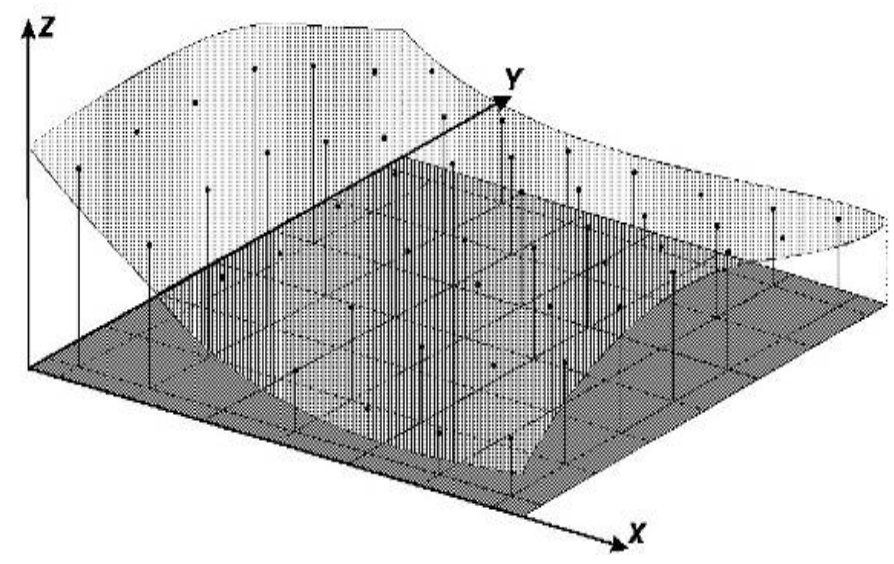

Figura 5 - Modelo de superfície gerada por grade regular (INPE, 2001)

$\mathrm{Na}$ modelagem da superfície por meio de grade irregular, cada polígono que forma uma face do poliedro é um triângulo (Figura 6). Os vértices 
do triângulo são geralmente os pontos amostrados da superfície. Esta modelagem permite que as informações morfológicas importantes como às descontinuidades, representadas por feições lineares de relevo (cristas) e drenagem (vales), sejam consideradas durante a geração de grade triangular, possibilitando modelar a superfície do terreno preservando as feições geomórficas da superfície (INPE, 2001).

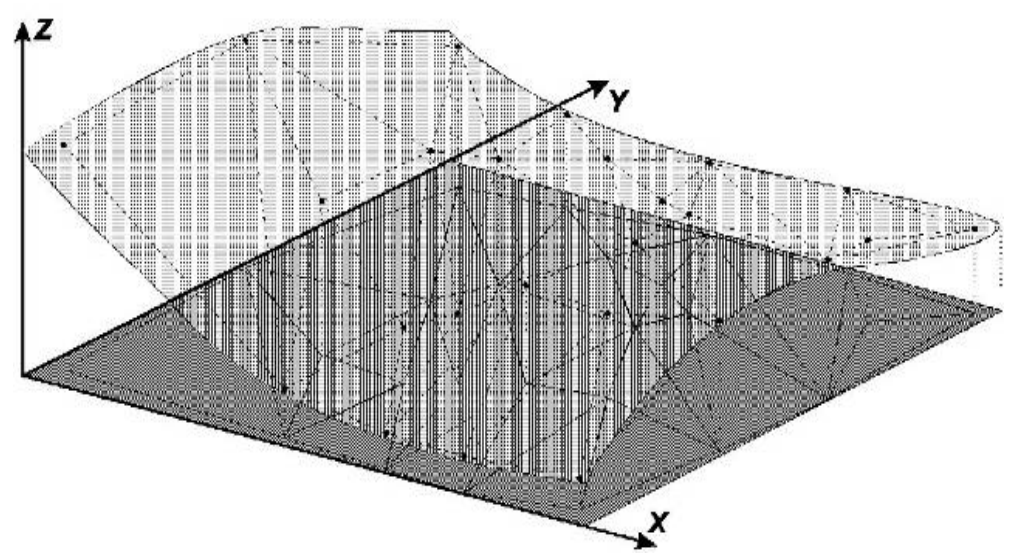

Figura 6 - Modelo de superfície gerada por grade irregular (INPE, 2001)

O número de redundância é bastante reduzido comparado à grade regular, uma vez que a malha é mais fina em regiões de grande variação e mais espaçada em regiões quase planas. As descontinuidades da superfície podem ser modeladas através de linhas e pontos característicos (INPE, 2001). Esta grade tem a vantagem de utilizar os próprios pontos amostrados para modelar a superfície, sem a necessidade de qualquer tipo de interpolação sobre os mesmos. A forma de como se ligam os pontos é determinado por um algoritmo chamado "triangulação de Delaunay", que liga determinado ponto apenas à seus vizinhos. Segundo Star \& Estes (1990), a desvantagem da grade irregular é que os procedimentos para obtenção de dados derivados de grades triangulares tendem a ser mais complexos e consequentemente mais demorados que os da grade retangular. 
Os métodos de interpolação mais utilizados para geração de grade regular de dados altimétricos são:

- Vizinho mais próximo: para cada ponto XY da grade é atribuído o valor da amostra mais próxima ao ponto (Figura 7). Este interpolador deve ser usado quando se deseja manter os valores amostrais na grade sem gerar valores intermediários (INPE, 2001).

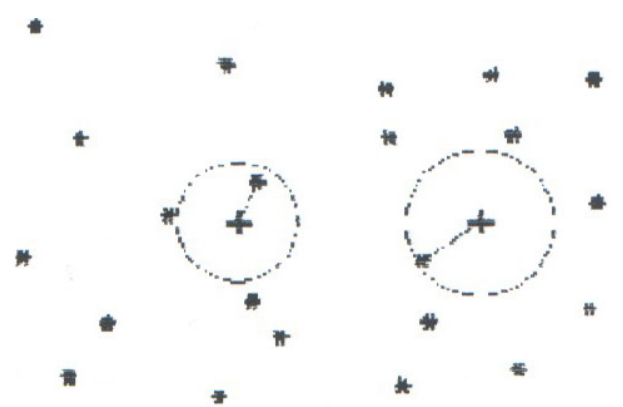

Figura 7 - Interpolação por vizinho mais próximo (INPE,2001)

- Média simples: o valor do atributo de cada ponto da grade é estimado a partir da média simples dos atributos dos oitos vizinhos mais próximos desse ponto com visto na Figura 8, eq. (1). Utilizando geralmente quando se requer maior rapidez na geração da grade, para avaliar erros grosseiros na digitalização (INPE,2001).

$F(x, y)=\frac{1}{n}\left(\sum_{n}^{8} z i\right)$

onde:

$\mathrm{n}=$ número de vizinhos;

$\mathrm{z}=$ valor de atributo dos $\mathrm{n}$ vizinhos;

$\mathrm{i}=1$;

$F(x, y)=$ função interpolante, 


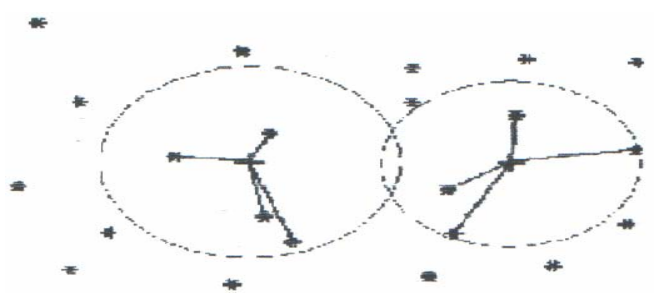

Figura 8 - Interpolação por média simples (INPE, 2001)

- Média ponderada: o valor do atributo de cada ponto da grade é calculado a partir da média ponderada dos oito vizinhos mais próximos a este ponto, eq. (3), por uma função que considera a distância do ponto amostral ao ponto da grade, eq. (2). Produz resultados intermediários entre o interpolador de média simples e os outros interpoladores mais sofisticados, num tempo de processamento menor (INPE, 2001).

$d=\left(\left(x-x_{0}\right)^{2}+\left(y-y_{0}\right)^{2}\right)^{\frac{1}{2}}$

onde:

d = distância euclidiana do ponto interpolante ao vizinho i;

$\mathrm{w}(\mathrm{x}, \mathrm{z})=(1 / \mathrm{d})^{\mathrm{u}=1}$;

$u=1$ = expoente da função de ponderação;

$F(x, y)=\frac{\left(\sum_{1}^{8} W(x, y)\right) *{ }^{2}}{\sum_{1}^{8} W(x, y)}$

onde,

$W(x, y)$ - função de ponderação;

$F(x, y)$ - função de interpolação;

- Média ponderada por quadrante: calcula a média ponderada a função de interpolação anterior. É considerado um "amostrador" por quadrante (total de quatro amostras) e o número de pontos amostrados é igual para cada um dos quadrantes (Figura 9). Deve-se utilizar quando as amostras são todas do tipo "ponto" (INPE, 2001). O valor de atributo por quadrante é em relação ao peso proporcional ao Inverso da distância dos valores amostrados. 


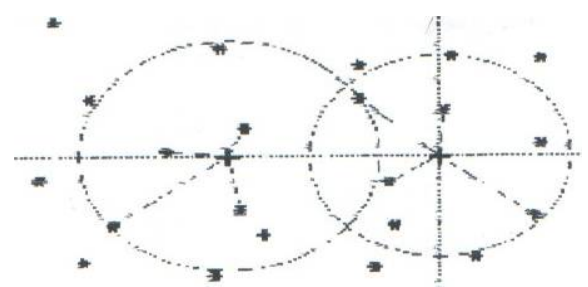

Figura 9 - Interpolação por média ponderada por quadrante (INPE, 2001)

- Média ponderada por cota e por quadrante: este interpolador também realiza a mesma função de interpolação vista anteriormente. Além da restrição de quadrante do método anterior, o número de amostras por valor de elevação é limitado (Figura 10). É recomendado quando as amostras são do tipo isolinhas (INPE, 2001).

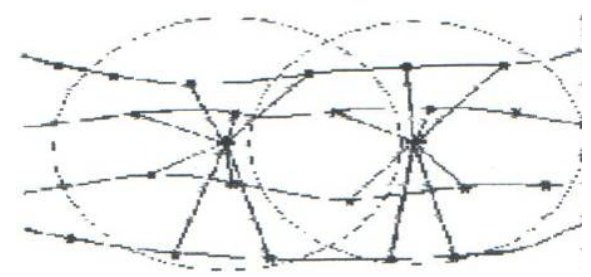

Figura 10 - Interpolação por média ponderada por cota e quadrante (INPE,2001)

\subsubsection{Elaboração de produtos MNT}

Os produtos obtidos a partir de grades (triangulares ou regulares) podem ser visualizados pelas seguintes representações: imagem em níveis de cinza, imagem sombreada, projeção $3 \mathrm{D}$, geração de isolinhas, geração de declividade, fatiamento do modelo numérico (PETRIE \& KENNIE, 1990).

\subsubsection{Imagem em níveis de cinza}

Essa imagem é gerada diretamente do mapeamento dos valores do atributo do modelo para valores de nível de cinza. Supondo-se que cada pixel da imagem de nível de cinza é representada por oito bits pode-se mapear os 
atributos para valores de nível de cinza de 0 a 255 (Surfer,1999). A Figura 11 ilustra o mapeamento do valor de um atributo $Z_{i}$ para um valor de nível de cinza $\mathrm{NC}_{\mathrm{i}}$.

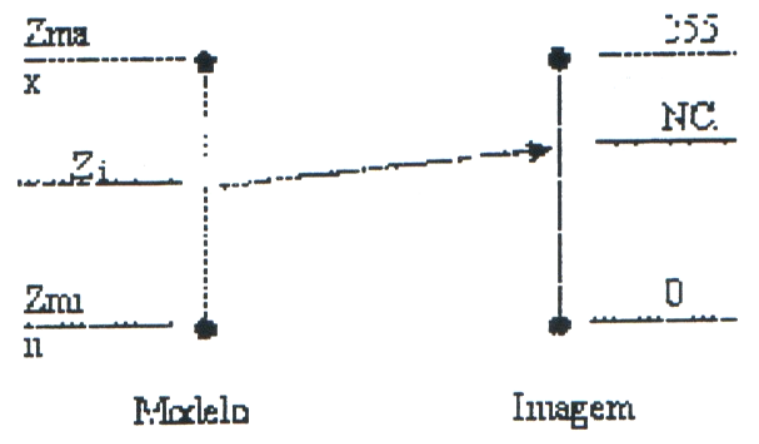

Figura 11 - Mapeamento de valores de atributo para um valor de níveis de cinza (INPE,2001)

Segundo INPE (2001), considerando o mapeamento linear dos valores de atributo do modelo para valores de níveis de cinza, quantização linear, podese calcular o valor $\mathrm{NC}_{\mathrm{i}}$ em função de $Z_{\mathrm{i}}$ através da eq. (4):

$$
\left.N C_{i}=\left\{\left(Z_{i}-Z_{\text {mim }}\right) * 254\right] /\left(Z_{\text {max }}-Z_{\text {min }}\right)\right\}+1
$$

Esta equação mapeia os valores do fenômeno representado para valores entre 1 a 255 da imagem. O valor de nível de cinza igual a "0" é usado em áreas onde não existe definição do valor de atributo para o modelo (INPE, 2001).

A Figura 12 mostra uma imagem em níveis de cinza obtida a partir de um modelo numérico do terreno. Essa imagem é utilizada para obter uma percepção visual global qualitativa da variação de um fenômeno. 


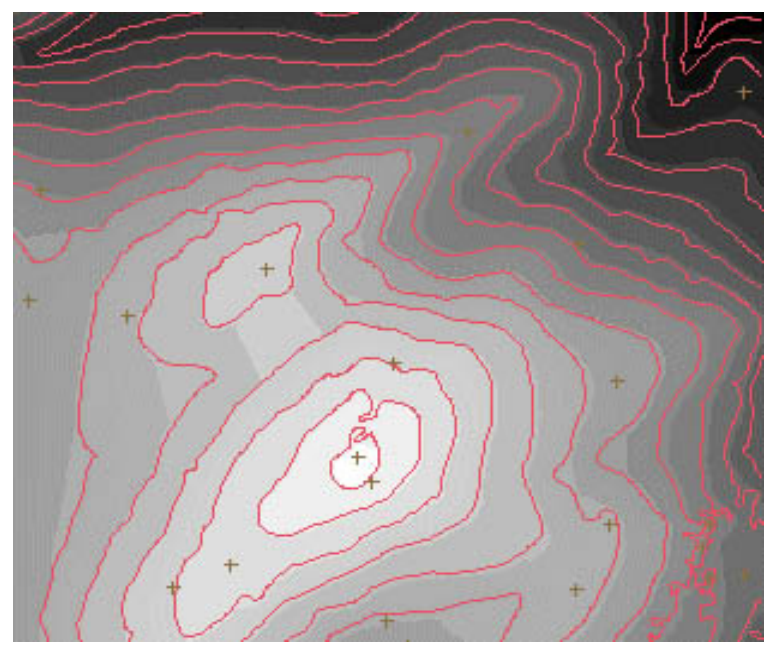

Figura 12 - Imagem em níveis de cinza com curvas de nível sobreposta

\subsubsection{Geração de isolinhas}

Isolinhas são curvas que conectam pontos da superfície com mesmo valor de atributo. As isolinhas podem ser determinadas a partir de interceções da superfície com planos horizontais. A projeção das interceções no plano $X Y$ define as isolinhas. Partindo-se do pressuposto que a superfície representada é uma função matemática definida no espaço $X Y$ então as isolinhas tem a propriedade de nunca se cruzarem (INPE, 2001).

As isolinhas são obtidas a partir de interceções com as arestas dos elementos básicos, retângulo (Figura 13) ou triângulo (Figura 14), do modelo.

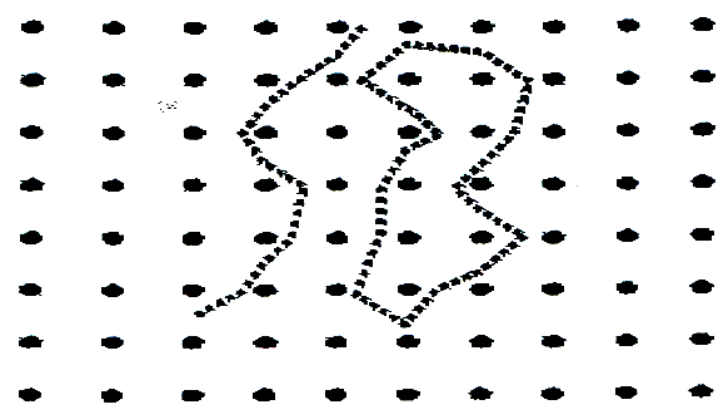

Figura 13 - Geração de isolinhas a partir do modelo de grade retangular (INPE,2001) 


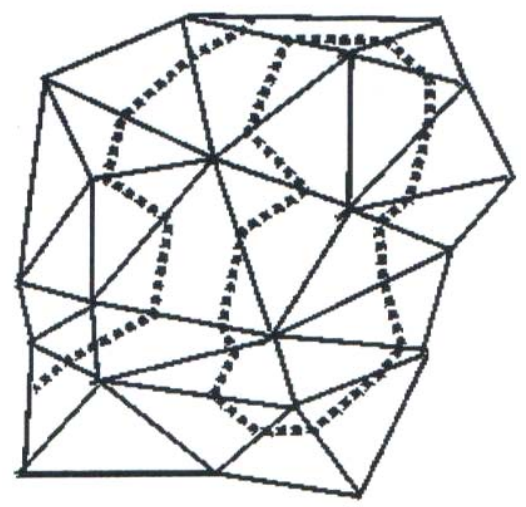

Figura 14 - Geração de isolinhas a partir do modelo de grade triângular (INPE,2001)

Segundo INPE (2001), existem dois métodos de geração de mapas de contornos a partir do modelo de grade: o método seguidor de linhas e o método de segmentos. O método seguidor de linhas é um método que gera cada linha de contorno em um único passo. Por esse método procura-se um segmento que pertence a uma curva de contorno. Em seguida busca os outros segmentos que tem ligações com essas extremidades. Os novos segmentos encontrados são incorporados à linha e definem as novas extremidades. O processo para quando as extremidades se encontram, definindo uma isolinha fechada, ou quando as duas extremidades já encontraram as bordas da região de interesse. $\mathrm{O}$ método de segmentos cria as isolinhas em duas etapas. Na primeira etapa determinam-se todos os segmentos pertencentes a um valor de atributo predeterminado. Numa segunda etapa é necessário conectar esses segmentos a fim de se definir as isolinhas que pertencem ao valor da variável preestabelecida. Este processo de geração de mapa de contornos é automático e necessita apenas de definição do modelo e das curvas a serem geradas. Essas curvas podem ser definidas individualmente ou com espaçamento constante.

Como as isolinhas são representadas por um conjunto de pontos, às vezes o número de pontos é pequeno para uma determinada resolução (Figura 
15), é possível então (para melhor representação) aumentar o número de pontos nessa região ou se isso não for possível, gerar mais pontos por interpolação ou aproximação (Figura 16).

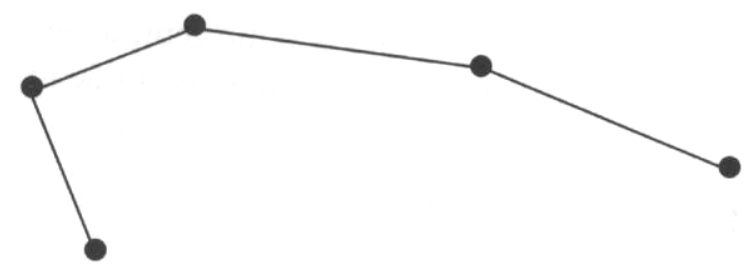

Figura 15 - Isolinha com pequena resolução (Azevedo \& Conci, 2003)

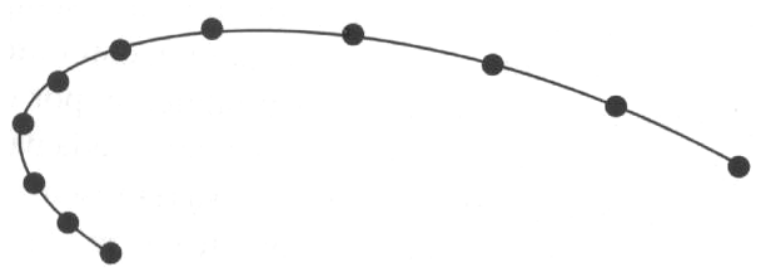

Figura 16 - Isolinha com muita resolução (Azevedo \& Conci, 2003)

Definir uma curva que passe por um conjunto determinado de pontos é um problema distinto de procura da melhor curva para representar um conjunto determinado de pontos. Existem vários métodos de representação de curvas. Um dos mais utilizados é o método de curvas paramétricas de terceira ordem de Splines (Azevedo \& Conci, 2003).

Segundo Minghin (1980), o nome Spline faz alusão ao termo da língua inglesa utilizado para denominar a régua flexível usada em desenho para gerar curvas livres suave. A expressão matemática que descreve essa régua é denominada Spline Cúbica Natural. Nessa expressão, as alterações em qualquer um dos pontos de controle provocam alterações em toda a curva. A BSpline é uma versão da Spline Natural, com controle local, isto é, as alterações nos pontos de controle da B-Spline apenas se propagam para os vizinhos mais próximos. A função B-Spline não passa pelos pontos de controle (Figura 17). 


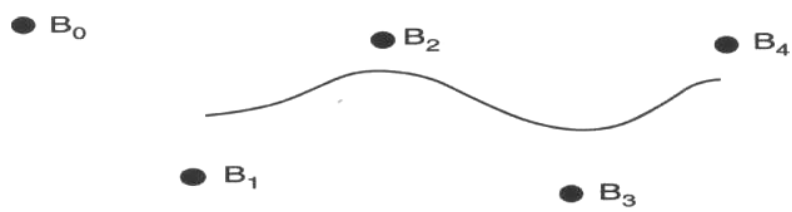

Figura 17 - Comportamento de isolinhas pela função B-Spline (Azevedo \& Conci, 2003)

\subsubsection{Fatiamento do modelo numérico}

Segundo Pettinati (1983), fatiamento de um modelo consiste em definir intervalos, ou fatias, de valores com a finalidade de gerar uma imagem temática a partir do modelo. Assim, cada tema ou classe da imagem temática, é associado a um intervalo de atributos dentro dos valores atribuídos ao fenômeno modelado. O usuário de SIG é responsável pela definição das fatias e também da associação dessas fatias com classes predefinidas no sistema. As fatias são definidas de acordo com intervalos das variáveis que são úteis para uma determinada aplicação. A Figura 18 ilustra o processo de fatiamento do modelo.
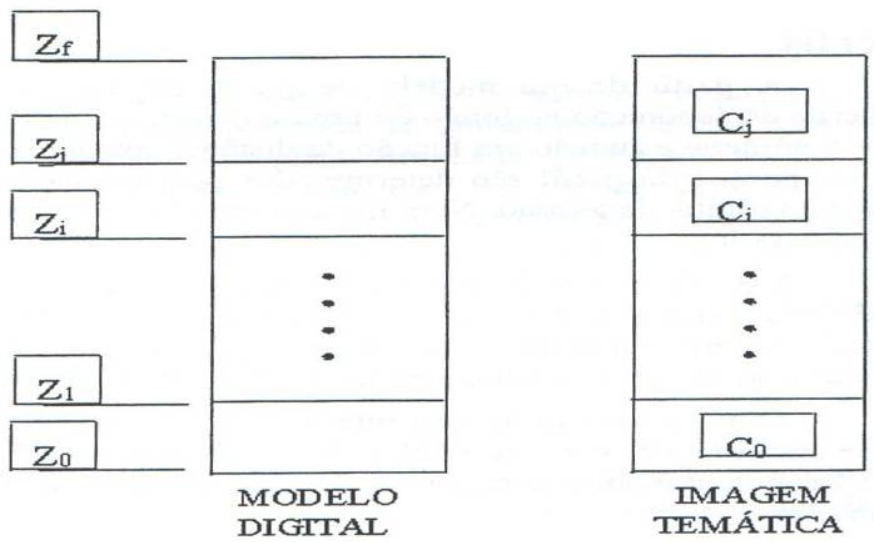

Figura 18 - llustração do processo de fatiamento do MNT (INPE,2001)

Da figura acima temos que a $\mathrm{C}_{0}$ está associada ao intervalo de atributos entre $Z_{0}$ e $Z_{1}$, a classe $C_{i}$ está associada ao intervalo de atributos entre 
$Z_{i}$ e $Z_{j}$, e assim por diante. Os valores de cota $Z_{0}$ e $Z_{f}$ representam os extremos desse modelo. Quando um intervalo não for associado a nenhuma classe devese atribuir o valor de nível de cinza "0" para os pixels da imagem que representam valores nesse intervalo.

A imagem temática gerada pelo fatiamento do modelo é geralmente usada em análises espaciais como operações lógicas de interceção e união. A Figura 19 mostra uma imagem temática criada a partir de um modelo numérico do terreno.

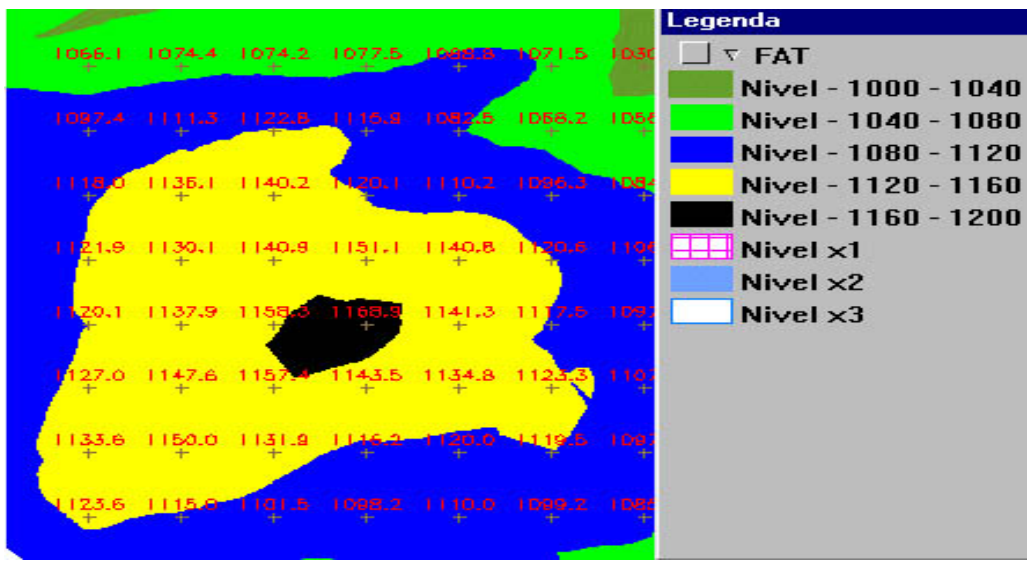

Figura 19 - Mapa de fatiamento gerado por um MNT (INPE,2001)

\subsection{Estrutura das imagens digitais}

As imagens digitais são constituídas por um arranjo de elementos sob a forma de uma malha ou grade. Cada cela dessa grade tem sua localização definida em um sistema de coordenadas do tipo linha e coluna, representadas por "U" e "V" respectivamente. Por convenção, a origem da grade é sempre no seu canto superior esquerdo. O nome dado a essas celas é pixels, derivado do inglês "picture element". Cada cela possui também um atributo numérico " $Z$ ", que indica o nível de cinza dessa cela, que obviamente vai variar do preto ao branco, esse nível de cinza é conhecido em inglês por DN, de "digital number". O DN de uma cela representa a intensidade da energia eletromagnética 
(refletida ou emitida) medida pelo sensor, para a área da superfície da Terra correspondente ao tamanho do pixel (Crósta, 1992).

A Figura 20 exemplifica uma imagem, composta apenas por áreas quase brancas e quase pretas, e sua respectiva matriz numérica, representando a forma pela qual essa imagem seria utilizada no processamento digital.
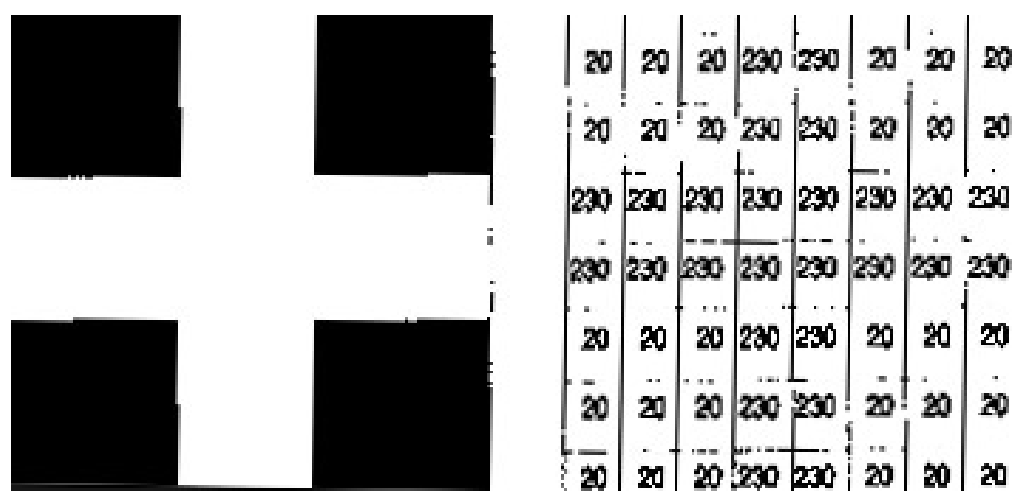

Figura 20 - Exemplo de uma imagem (cruz), em que, seu formato digital é representada por uma matriz numérica (Crosta, 1992)

Qualquer imagem pode ser transformada em imagem digital através de um processo conhecido como digitalização. Esse processo é implementado através de um tipo de equipamento periférico denominado "scanner", que transforma uma imagem analógica (fotografias, mapas, etc.) em uma matriz com número de linhas e colunas e tamanho pré-definido de cada cela, atribuindo para cada um, valores de nível de cinza proporcional à tonalidade da imagem original. Essa matriz é então convertida para um formato digital gráfico, podendo ser lida e manipulada por sistemas de processamento digitais (Scarin \& Teixeira, 1994). 


\subsubsection{Características dos monitores de computador}

A maioria dos modelos atuais se baseia na tecnologia de tubos de raios catódicos (CRT - Catode Ray Tube). Os monitores CRT são compostos por um canhão que gera um feixe de elétrons. Um aquecedor é utilizado para liberar elétrons de um cátodo, razão, pelos quais os monitores demoram um pouco para apresentar a primeira imagem depois de ligado. Esses elétrons são atraídos por anodos (cargas positivas) próximos à parte da frente do monitor (Figura 21). O feixe de elétrons percorre um caminho da esquerda para a direita e de cima para baixo, orientado por diversos componentes chamados bobinas defletoras. Ao atingir a extremidade direita da tela, o feixe é desligado para retornar à extrema esquerda da linha inferior e, quando atinge a extremidade de baixo, também é desativado para retornar novamente à primeira linha. Esse processo é chamado de varredura. Aumentando ou diminuindo a intensidade do feixe, consegue-se controlar o brilho dos pontos de fósforo da tela para gerar a imagem. A velocidade com que o feixe percorre toda a tela é chamada de taxa de renovação ou freqüência de varredura vertical (Azevedo \& Conci, 2003).

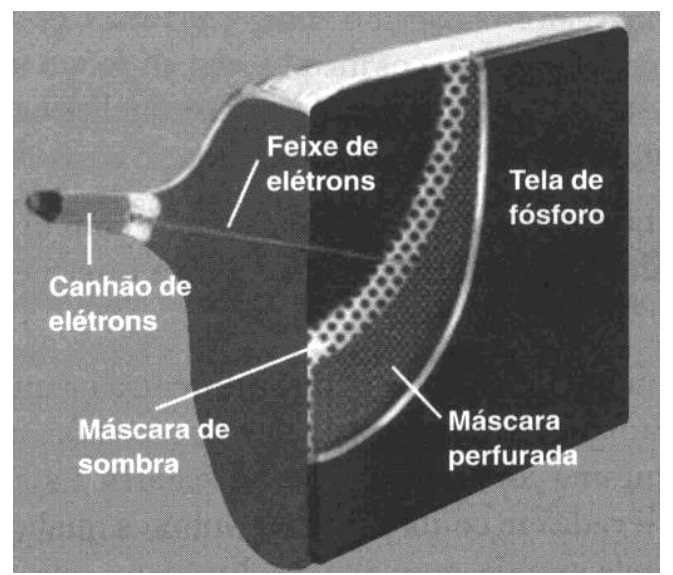

Figura 21 - Tubo de raio catódico (Azevedo \& Conci, 2003)

No Brasil, os monitores CRT coloridos usam o padrão RGB (Red, Green e Blue), um sistema de representação de todas as cores com base no vermelho, verde e azul. Para gerar qualquer cor do espectro, os monitores 
coloridos precisam de três sinais separados, que vão sensibilizar, respectivamente, os pontos de fósforo das três cores primárias, suficientemente pequenos para parecer ao olho humano como um único ponto de luz (Azevedo \& Conci, 2003).

\subsubsection{Representação vetorial e matricial de imagens}

Um vetor é basicamente um segmento de reta orientado. Pensa-se em um vetor $2 \mathrm{D}, \mathrm{V}$, como uma seta que vai da origem do sistema de coordenadas, para o ponto de coordenadas $(\mathrm{x}, \mathrm{y})$, tendo assim uma direção, um sentido e um comprimento especificado. Uma matriz é um arranjo de elementos em duas direções. Quando se trabalha com matriz, primeiro define-se quantos elementos existem em cada direção, uma matriz 4x4, por exemplo, é visualizado na Figura 22 (Azevedo \& Conci, 2003).

\begin{tabular}{|l|l|l|l|}
\hline 1 & 0 & 0 & 0 \\
\hline 0 & 1 & 0 & 0 \\
\hline 0 & 0 & 1 & 0 \\
\hline 0 & 0 & 0 & 1 \\
\hline
\end{tabular}

Figura 22 - Representação de matriz (Azevedo \& Conci, 2003)

A representação vetorial das imagens é principalmente empregada, em computação gráfica, para a definição e modelagem dos objetos sintéticos que serão representados pela imagem. Na representação vetorial das imagens, são usados como elementos básicos os pontos, as linhas, as curvas, as superfícies tridimensionais ou mesmo os sólidos que descrevem os elementos, que formam as imagens sinteticamente no computador. Esses elementos são denominados primitivas vetoriais da imagem. As primitivas vetoriais são associadas a um conjunto de atributos que define sua aparência e a um conjunto de dados que define sua geometria. A cada elemento de um conjunto de pontos associa-se uma posição, que pode ser representada por suas coordenadas (geometria), e uma cor, que será como esses pontos aparecerão 
na tela (atributos). No caso de um conjunto de linhas retas, cada uma pode ser definida pelas coordenadas de seus pontos extremos e sua cor, espessura, ou ainda se aparecerá pontilhada ou tracejada (Anand, 1993).

A descrição matricial é típica das imagens digitalizadas, capturadas por scanners ou utilizadas nos vídeos. É a forma de descrição principal na análise e no processamento de imagens. Na representação matricial, a imagem é descrita por um conjunto de células em um arranjo espacial bidimensional, uma matriz. Cada célula representa os pixels (ou pontos) da imagem matricial. Os objetos são formados usando adequadamente esses pixels (Crósta,1992).

\subsubsection{Cores}

As cores primárias são as cores básicas que podem ser usadas para produzir outras cores. As cores podem ser produzidas a partir de uma combinação das primárias, ou então, da composição de suas combinações. Não existe um conjunto finito de cores primárias visíveis que produza realmente todas as cores, mas sabe-se que uma grande parte delas pode ser produzida realmente a partir de três primárias escolhidas das extremidades e centro do espectro de luzes visíveis como, por exemplo, as luzes vermelha, verde e azul, conhecidas como primárias RGB. A razão pela qual se usam três cores primárias é pelo fato de os olhos humanos possuírem três tipos de sensores coloridos diferentes, sensíveis a diferentes partes do espectro de luz visível. Eles são os chamados fotopigmentos, se localizam nos comprimentos de onda das luzes azul, verde e amarelo e respondem às sensações luminosas em todo o resto do espectro das radiações visíveis (Azevedo \& Conci, 2003).

Segundo Marcus (1987), um sistema de cores é um modelo que explica as propriedades ou o comportamento das cores num contexto particular. Não existe um sistema que explique todos os aspectos relacionados à cor. Por isso, são utilizados sistemas diferentes para ajudar a descrever as diferentes 
características das cores e sua percepção pelo ser humano. Existem vários sistemas de cores, os mais utilizados são: o XYZ, o RGB, o HSV e o HLS.

Os sistemas de cores podem ser aditivos ou subtrativos.

Segundo Azevedo \& Conci (2003), o sistema de cores aditivo é o sistema usado nos monitores de vídeo e televisão, no qual a cor é gerada pela mistura de vários comprimentos de onda luminosa provocando uma sensação de cor quando atinge e sensibiliza o olho. As cores primárias aditivas do sistema RGB são: vermelho, verde e azul. No processo aditivo, o preto é gerado pela ausência de qualquer cor, indicando que nenhuma luz está sendo transmitida; o branco é a mistura de todas elas, o que indica que uma quantidade máxima de vermelho, verde e azul está sendo transmitida (Figura 23).

Figura 23 - Processo aditivo das cores primárias (Azevedo \& Conci, 2003)

Em uma imagem colorida, a representação da cor C de cada pixel da imagem pode ser obtida matematicamente pela eq. (5):

$C=r \cdot R+g \cdot G+b \cdot B$

Onde $R, G$ e $B$ são as três cores primárias e $r$, $g$ e $b$ são os coeficientes de mistura correspondentes a cada uma das intensidades associadas a cada um dos canais RGB. Esses coeficientes de mistura podem ser números reais ou inteiros. A primeira forma é mais utilizada para 
transformação entre espaços de cor, ou consultas digitais em sua armazenagem na forma de arquivos de imagens. Dessa forma, a cor $\mathrm{C}$ de cada pixel da imagem pode ser plotada no espaço de cores RGB usando-se os coeficientes de mistura ( $r, g, b)$ como coordenadas. Uma cor, portanto, pode ser considerada como um ponto em um espaço tridimensional (modelada com um subconjunto do espaço $\mathrm{R}^{3}$ ou $\mathrm{N}^{3}$ ), onde cada cor possui uma coordenada ( $r, g$, b) (Azevedo \& Conci, 2003).

O sistema de cores subtrativo é o processo usado nas impressoras e pinturas. Uma pintura é diferente de um monitor que, por ser uma fonte de luz, pode criar cores. As cores primárias do sistema CMY para objetos sem luz própria são: ciano, magenta e amarelo; são cores primárias subtrativas, pois seu efeito é subtrair, isto é, absorver alguma cor da luz branca. Quando a luz branca atinge o objeto, ela é parcialmente absorvida pelo objeto. A parte que não é absorvida é refletida, e eventualmente atinge o olho humano, determinando assim a cor do objeto. O processo subtrativo altera a cor através de uma diminuição (da luz incidente) dos comprimentos que são absorvidos (Figura 24). No processo subtrativo, o branco corresponde à ausência de qualquer cor e o preto é a presença de todas (Azevedo \& Conci, 2003).

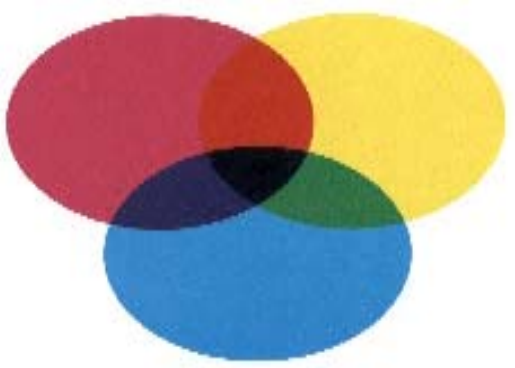

Figura 24 - Processo subtrativo das cores secundárias (Azevedo \& Conci, 2003)

No processo subtrativo, uma cor é vista como:

- ciano: caso absorva a componente vermelha da luz branca refletida; a luz branca é a soma das cores azul, verde e vermelho, assim, em termos de cores aditivas, ciano é a soma de verde e azul. 
- magenta: caso retire toda a componente verde da luz branca, sendo assim, a soma das cores aditivas vermelho e azul.

- amarelo: caso subtraia toda a componente azul da luz branca refletida, é a soma das cores aditivas verde e vermelho.

Segundo Marcus (1987), pode-se ainda obter outros tipos de cores através de combinação. As cores secundárias, por exemplo, são obtidas pela combinação das primárias, duas a duas, em proporções iguais (Figura 25).

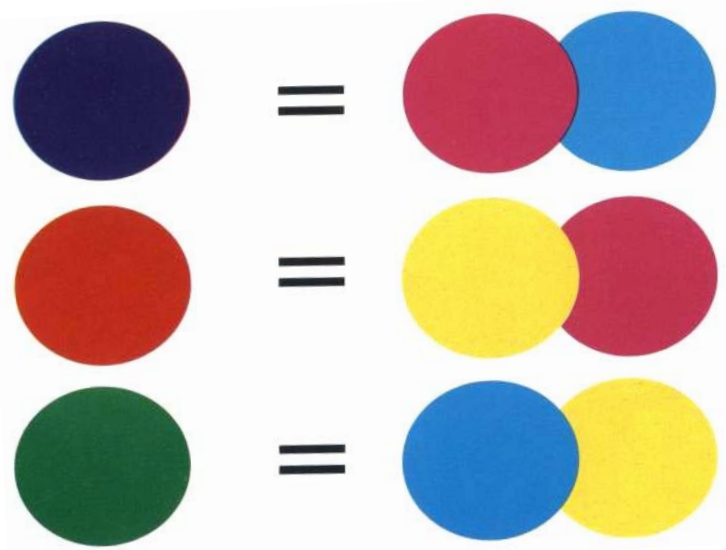

Figura 25 - Processo de obtenção das cores secundárias

(Azevedo \& Conci, 2003)

\subsubsection{Conversão de dados e de imagens}

Crósta (1992) comenta que o processo de digitalização de imagem analógica (fotografia, mapas, etc) pode ser implementado através de um scanner, gerando uma matriz que é então convertida para o formato digital gráfico, podendo ser lida e manipulada por sistemas de processamento digitais.

Uma vez que as fotografias estejam no formato digital, suas feições podem ser digitalizadas diretamente em tela, de forma manual, utilizando-se o cursor do computador. Quintanilha (1996) menciona que a digitalização em tela pode ser realizada ainda da forma semi-automática ou automática, quando 
essas feições são traçadas com o auxílio do software que executam o processo de forma semi-automática ou automaticamente.

Devido às distorções geradas por alterações dinâmicas sofridas pelos sistemas de imageamento, as imagens de sensoriamento remoto não se ajustam diretamente a um sistema de gradeamento cartográfico. Segundo Crósta (1992), esta série de distorções a que estão sujeitas imagens de sensores remotos de qualquer tipo, ocasionam a falta de precisão cartográfica e, consequentemente, de posicionamento dos objetos. Portanto, dependendo da precisão requerida para aplicação em mapeamento, e/ou da necessidade de junção de imagens para representar uma cena completa (mosaico), essas distorções precisam ser corrigidas por um sistema de projeção cartográfica de referência pré-estabelecida.

Crósta (1992) cita duas formas pelas quais é calculada a relação entre os dois sistemas de coordenadas. A primeira delas é através do conhecimento exato dos parâmetros geométricos da órbita do satélite e de outras variáveis, também chamada de modelo de geometria orbital. A segunda, e mais comum, se faz através de definição de pontos de controle no terreno, que têm de ser reconhecíveis tanto no mapa como na imagem.

Pontos de controle são feições passíveis de identificação na imagem e no terreno, ou seja, são feições homólogas cujas coordenadas são conhecidas na imagem e no sistema de referência. Cruzamento de estradas, pistas de aeroportos e confluência de rios são candidatos naturais a ponto de controle (Oliveira, 1988).

A determinação dos parâmetros da transformação polinomial selecionada é feita através da resolução de um sistema de equações. Para que esse sistema de equações possa ser elaborado as coordenadas dos pontos de controle devem ser conhecidas tanto na imagem de ajuste como no sistema de referência (INPE, 2001). As coordenadas da imagem são obtidas quando o usuário "clica sobre a feição da imagem". As coordenadas de referência são 
usualmente obtidas através de mapas confiáveis que contenham as feições homólogas usadas como pontos de controle.

Com o objetivo de expressar analiticamente a relação existente entre pontos do terreno e suas imagens na fotografia, foram desenvolvidos, ao longo do tempo, diferentes modelos matemáticos, sendo uns dos mais usados à equação de colinearidade (Manual of Photogrammetry, 1980).

$\mathrm{Na}$ Figura 26 ilustra o processo georreferenciamento de fotografias aéreas usando equação de colinearidade da fotogrametria, onde utiliza-se as coordenadas da fotografia (imagem a ser ajustada) e as coordenadas do sistema de referencia.

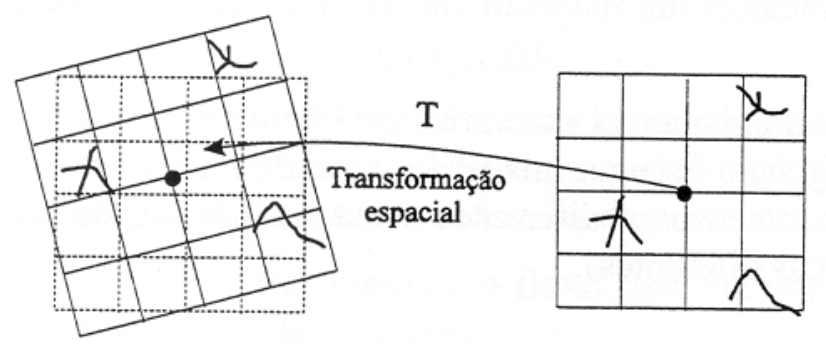

Imagem de ajuste Imagem de referência

Figura 26 - Operação de georreferenciamento (INPE, 2001)

Segundo Raffo (2000), o modelo das equações de colinearidade fundamenta-se nas equações da reta, da geometria analítica do espaço, e aplica-se ao alinhamento do conjunto de pontos, formado pelo centro da lente da câmara fotográfica, pelo ponto do terreno e sua imagem na fotografia (Figura 27).

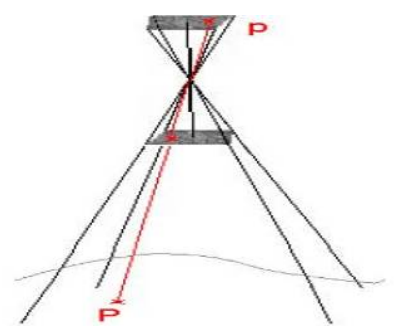

Figura 27 - Relação projetiva entre a fotografia e o terreno (Raffo, 2000) 
A Figura 27 demonstra a condição de colinearidade para um determinado ponto "P", e sua projeção na imagem "p". Observa-se que à fotografia está rebatida, localizando-se abaixo do centro de perspectiva (o plano superior do centro de perspectiva é o "negativo" da fotografia).

Segundo Ghosh (1988), em circunstâncias ideais, o sistema de eixos da fotografia e o sistema de eixos do terreno são totalmente paralelos (Figura 28).

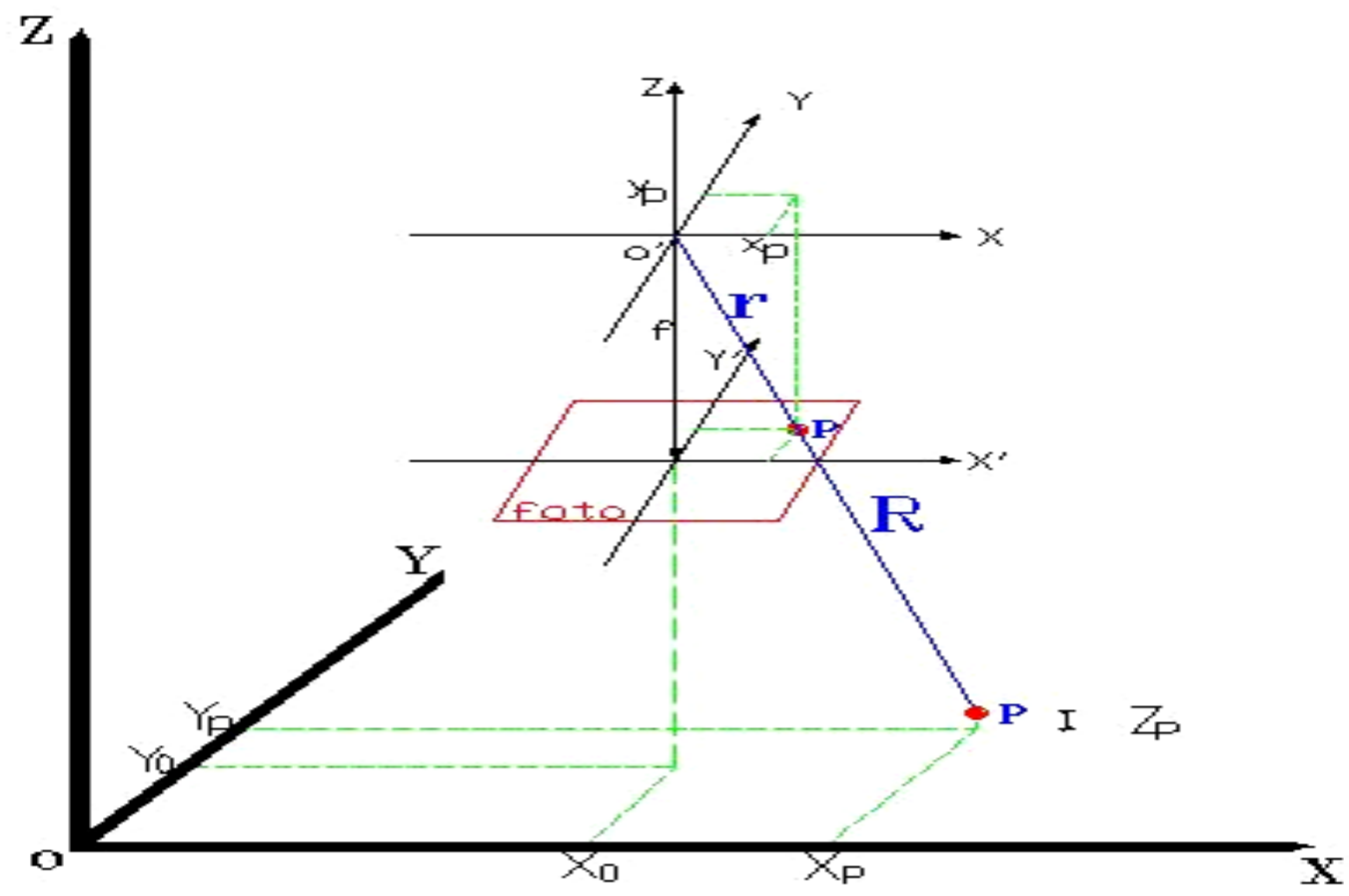

Figura 28 - Relação entre objeto e imagem com sistemas de eixos paralelos (Adaptado por Cabrera de Ghosh, 1988)

" $\mathrm{X}_{0}$ " representa a posição do centro de perspectiva no eixo $\mathrm{X}$ do sistema de coordenadas do espaço objeto.

" $Y_{0}$ " representa a posição do centro de perspectiva no eixo $Y$ do sistema de coordenadas do espaço objeto.

" $X_{p}$ " representa a coordenada $X$ do ponto objeto no sistema espaço objeto. 
" $Y_{p}$ " representa a coordenada $Y$ do ponto objeto no sistema espaço objeto.

O vetor "R" fica definido pelo ponto "P" no terreno e o centro de perspectiva da câmara fotográfica "O" (ponto, pelo qual, todos os raios de feixes de luz, vindo do terreno, passam para sensibilizar o filme fotográfico) e o vetor "r" pelo ponto de imagem "p" e o centro de perspectiva.

Segundo Raffo (2000), se o sistema de eixos do objeto e da imagem fosse paralelo, às equações de colinearidade seriam eq. (6):

$$
\begin{aligned}
& x_{p}=(-f)\left[\frac{X_{p}-X_{0}}{Z_{p}-Z_{0}}\right] \\
& y_{p}=(-f)\left[\frac{Y_{p}-Y_{0}}{Z_{p}-Z_{0}}\right]
\end{aligned}
$$

onde:

$x_{p}=$ coordenada $x$ da imagem;

$y_{p}=$ coordenada $y$ da imagem;

$\mathrm{f}=$ focal da câmara;

Como o sistema da câmara fotográfica nunca chega a ser perfeitamente paralelo ao sistema do terreno, devido aos movimentos e rotações que a câmara sofre durante o vôo, torna-se necessário ajustar o modelo matemático. Para compatibilizar os sistemas de coordenada, é atribuído a eq. (5) uma matriz de rotação $M$. A rotação existente entre os dois sistemas pode ser obtida com três rotações sucessivas, ao redor do eixo $X$ e das transformadas dos eixos $\mathrm{Y}$ e $Z$. A matriz $M$ será o produto de três matrizes de rotação, $M=M_{\omega} \cdot M_{\varphi} \cdot M_{K}($ Costa, 2000).

A Figura 29 representa a falta de paralelismo entre os eixos do plano da fotografia e do terreno. 


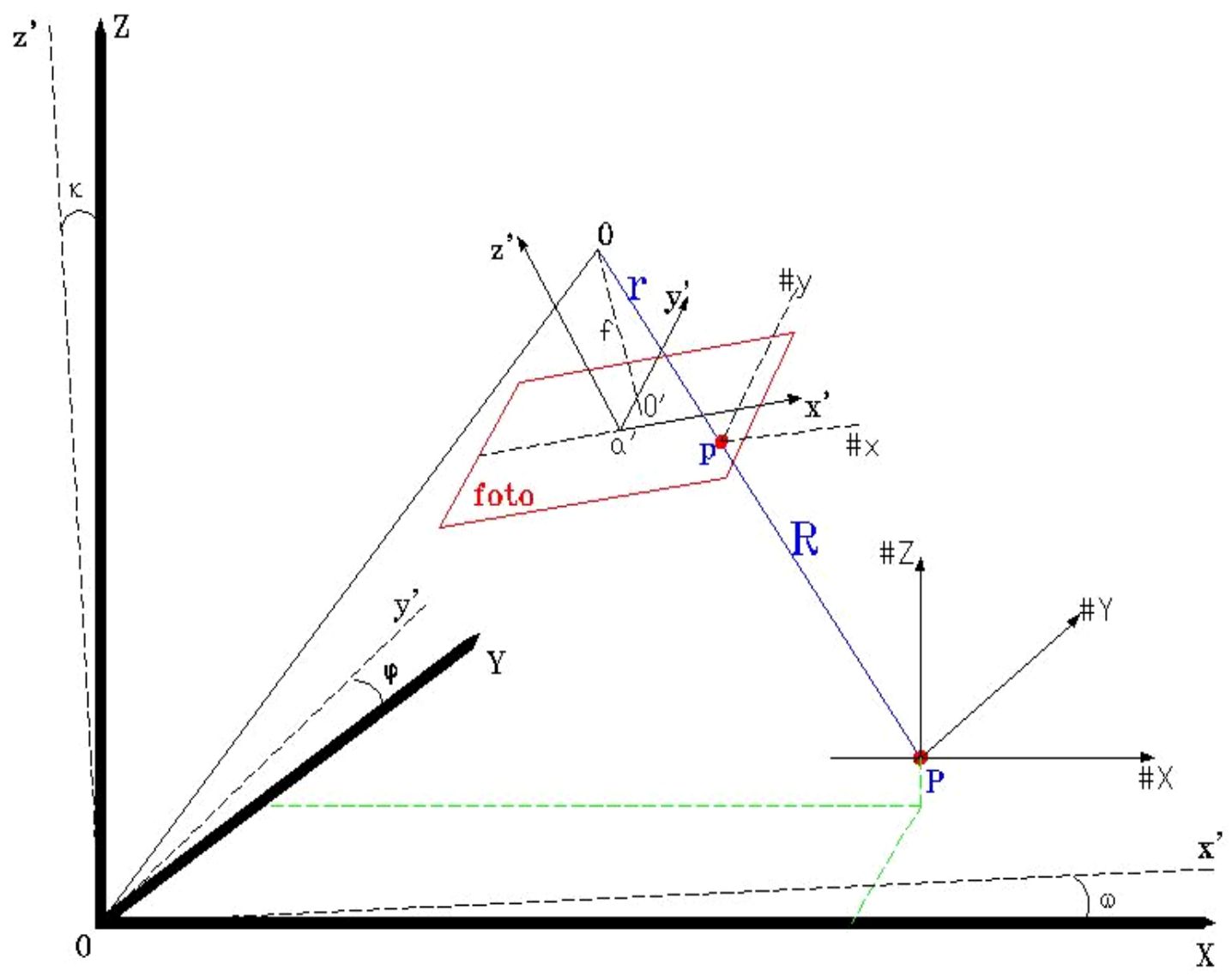

Figura 29 - Relação entre sistemas de coordenadas da fotografia e do terreno (Adaptado por Cabrera de Ghosh, 1988)

Segundo Costa (2000), os ângulos de Euler ( $\varphi, \omega$ e $\kappa)$ representam rotações sofridas pelo sistema local de coordenadas x, y e $z$ (da câmara) em relação ao sistema global do terreno X, Y e Z. Rotacionando-se x, y e z de $\varphi, \omega$ e $\kappa$, pode-se torná-lo paralelo a $X, Y$ e $Z$. A Figura 30 representa os ângulos de atitude do avião.

" $\omega$ " representa a rotação do eixo $x$ em relação a X. É contado no sentido anti-horário.

" $\varphi$ " representa a rotação do eixo y em relação a Y. É contado no sentido anti-horário.

"к" representa a rotação do eixo $z$ em relação a Z. É contado no sentido anti-horário. 


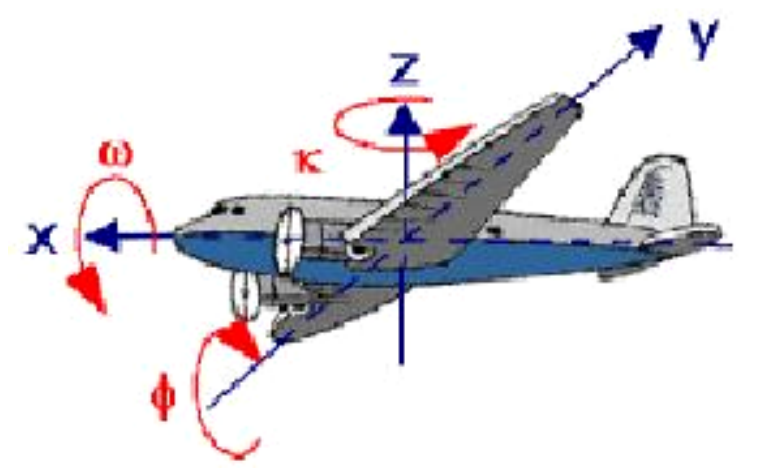

Figura 30 - Ângulos de atitude do avião (Ghosh, 1988)

Segundo Ghosh (1988), a matriz de rotação M de ajuste da imagem pode ser visualizada pela eq.(7).

$M=\left[\begin{array}{lll}m_{11} & m_{21} & m_{31} \\ m_{12} & m_{22} & m_{32} \\ m_{13} & m_{23} & m_{33}\end{array}\right]$

onde:

$\mathrm{m}_{11}=\cos \varphi \cdot \cos \mathrm{K} ;$

$\mathrm{m}_{21}=-\cos \varphi$. sen $\mathrm{\kappa}$;

$\mathrm{m}_{31}=\operatorname{sen} \varphi$;

$m_{12}=\cos \omega \cdot \operatorname{sen} \kappa+\operatorname{sen} \omega \cdot \operatorname{sen} \varphi \cdot \cos \kappa ;$

$\mathrm{m}_{22}=\cos \omega \cdot \cos \mathrm{K}-\operatorname{sen} \omega \cdot \operatorname{sen} \varphi \cdot \operatorname{sen} \kappa ;$

$\mathrm{m}_{32}=-\operatorname{sen} \omega \cdot \cos \varphi$;

$m_{13}=\operatorname{sen} \omega \cdot \operatorname{sen} \kappa-\cos \omega \cdot \cos \kappa \cdot \operatorname{sen} \varphi ;$

$\mathrm{m}_{23}=\operatorname{sen} \omega \cdot \cos \kappa+\cos \omega \cdot \operatorname{sen} \varphi \cdot \operatorname{sen} \kappa ;$

$\mathrm{m}_{33}=\cos \omega \cdot \cos \varphi$;

$\omega, \kappa, \varphi=$ ângulos de rotação.

Portanto as eq. (6) se transformam nas eq. (8). Estas equações são conhecidas como equações de colinearidade. 


$$
\begin{aligned}
& x_{p}=(-f) \cdot\left[\frac{m_{11}\left(X_{p}-X_{o}\right)+m_{21}\left(X_{p}-X_{o}\right)+m_{31}\left(Z_{p}-Z_{o}\right)}{m_{13}\left(X_{p}-X_{o}\right)+m_{23}\left(Y_{p}-Y_{o}\right)+m_{33}\left(Z_{p}-Z_{o}\right)}\right] \\
& z_{p}=(-f) \cdot\left[\frac{m_{12}\left(X_{p}-X_{o}\right)+m_{22}\left(Y_{p}-Y_{o}\right)+m_{32}\left(Z_{p}-Z_{o}\right)}{m_{13}\left(X_{p}-X_{o}\right)+m_{23}\left(Y_{p}-Y_{o}\right)+m_{33}\left(Z_{p}-Z_{o}\right)}\right]
\end{aligned}
$$

A distribuição dos pontos de controle na área a ser georreferenciada é de suma importância, pois as transformações polinomiais tendem a se comportar adequadamente apenas na região onde se encontram os pontos de controle. Por esse motivo é recomendado que os pontos se localizem bem distribuídos na imagem (Novo,1993).

Em áreas onde não existem mapas para determinação de pontos de controle são feitos levantamentos topográficos, medindo a posição geográfica de alguns pontos identificáveis nas imagens. Neste caso, pode ser usado receptores GPS Crósta (1992) e Wolf (1983).

A forma mais confiável de obtenção de pontos de controle é através de levantamento de campo, utilizando métodos geodésicos ou rastreamento de satélites de posicionamento. Porém, quando existem limitações para o uso destes métodos, a alternativa mais comum é a utilização de mapas em grande escala com fonte de dados (Delmiro, 1996).

No caso da digitalização em tela, as coordenadas do sistema da mesma devem ser substituídas pelas coordenadas do sistema de display, ou seja, as coordenadas que se lêem na tela, quando o cursor percorre a imagem.

A distribuição e quantidade desses pontos no terreno também precisam ser planejadas para que haja confiabilidade no processo. Farret (1996) e Farret \& Gioto (1997), em estudos de fotografias aéreas de pequeno formato, testaram várias geometrias para quatro pontos de controle bem definidos e verificaram que o menor valor de RMS (análise estatística na forma de erro médio quadrático, Root Mean Square error - RMS error, que expressa o grau de variação entre as medidas de coordenadas do sistema da mesa e do 
sistema escolhido) ocorreu com a distribuição dos pontos nos quatro cantos da fotografia.

Parise (1999), estudou fotografias aéreas georreferenciadas em processo de análise temporal de uso da terra em microbacias hidrográfica. Neste estudo, o autor comenta sobre a dificuldade de escolha dos pontos de controle, principalmente com relação à incerteza de que os pontos localizados na carta planialtimétrica correspondem corretamente àqueles determinados nas fotografias aéreas. Segundo o autor, na esperança de alcançar uma melhor correção das distorções e, ao mesmo tempo, garantir uma maior confiabilidade dos dados e um grau de exatidão aceitável, foi preferida uma distribuição similar à recomendada por Farret (1996) e Farret \& Giotto (1997).

\subsection{Princípios computacionais}

No desenvolvimento de softwares, existe uma preocupação com as lógicas internas e a estrutura funcional e operacional das ferramentas existentes no mesmo. Através de algoritmos matemáticos o programador consegue oferecer ao usuário a interação de um ambiente computacional, ou seja, construir estruturas operacionais de estudo de dados, possibilitando analisar, comparar, selecionar e manipular variáveis espaciais.

\subsubsection{Fundamentos matemáticos para o algoritmo a ser utilizado}

Para se obter o valor de atributos dos pontos coletados pelo software desenvolvido, utiliza-se o método de interpolação linear.

Neste método parte-se da suposição de que a "diferença de nível entre os atributos" da isolinha seja constante. 


\subsubsection{Fundamentos sobre banco de dados}

De forma simplificada, um banco de dados é uma coleção de informações. Entretanto, no linguajar comum da área de computação, um banco de dados é uma coleção de informações relacionadas, armazenadas e uma forma estruturalmente bem definida (Nelson, 1994).

Os dados geralmente são armazenados em tabelas e segundo Furtado (1986), uma tabela é uma coleção de registros que contém a mesma estrutura e um grupo de tabelas relacionadas constitui um banco de dados.

A Figura 31 ilustra a estrutura do banco de dados de doninha (pequeno mamífero carnívoro) de topete.

\begin{tabular}{|c|c|c|c|c|c|c|c|}
\hline $\begin{array}{c}\text { Número } \\
\text { de } \\
\text { Registro }\end{array}$ & Nome & Cor & Peso & Tamanho & $\begin{array}{c}\text { Data_ } \\
\text { nascimento }\end{array}$ & $\begin{array}{c}\text { Cor_- } \\
\text { topete }\end{array}$ & $\begin{array}{c}\text { Compr_ } \\
\text { topete }\end{array}$ \\
\hline 1 & Slegmund & Marrom & 300 & 25 & $13 / 09 / 91$ & Marrom & 10 \\
\hline 2 & Sieglinda & Marrom claro & 250 & 23 & $29 / 10 / 91$ & Preto & 10 \\
\hline 3 & Siegtriod & Marrom & 200 & 20 & $1309 / 92$ & Marroro & 3 \\
\hline 4 & & & & & & & \\
\hline
\end{tabular}

Figura 31 - Exemplo de estrutura de banco de dados (Furtado,1934)

Controlar esse tipo de informação tornou-se uma incumbência tão comum que deu origem ao desenvolvimento de sistemas de gerenciamento de bancos de dados (S.G.B.Ds). S.G.B.D é um software responsável pelo gerenciamento (armazenamento e recuperação) dos dados no banco de dados. Eles simplificam a criação e manutenção de bancos de dados. Um S.G.B.D pode ser produzido e comercializado por uma firma fabricante de computadores ou por uma que se dedique exclusivamente à produção de programas. No 
segundo caso se destacam os produtos Access da Microsoft, FoxPro da Microsoft, Paradox da Borland e o FileMaker da Claris etc (Furtado, 1934).

\subsection{Fundamentos da teoria dos erros}

Geralmente, ocorrem erros de vários tipos em uma mesma medida. Entretanto, esses diferentes tipos de erros podem ser separados em dois grandes grupos que são erros estáticos e erros sistemáticos (Raffo, 2000).

Erros estáticos resultam de variações aleatórias no valor medido de uma grandeza, devido a fatores que não podem ser controlados. Geralmente, essas variações se devem somente ao processo de medida, mas em alguns casos, as variações aleatórias também ocorrem na própria grandeza (Vuolo, 1992).

Erros sistemáticos é um erro tal que as $\mathrm{n}$ medidas são iguais, mas diferem do valor verdadeiro. Admitindo a ausência de erro estático, o erro sistemático pode ser representado pela eq. (9):

$\eta_{\mathrm{s}}=\mathrm{y}-\mathrm{y}_{\mathrm{v}}$

onde:

$\eta_{\mathrm{s}}=$ erro sistemático;

$\mathrm{y}=$ valor medido;

$\mathrm{y}_{\mathrm{v}}=$ valor real.

Erros sistemáticos podem ter causas diversas e geralmente se enquadram em: erros sistemáticos instrumentais, erros sistemáticos teóricos, erros sistemáticos ambientais e erros sistemáticos observacionais (Vuolo, 1992).

- Erros sistemáticos instrumentais: são os erros que resultam da calibração do instrumento de medida (Raffo, 2000);

- Erros sistemáticos teóricos: são os erros que resultam do uso de fórmulas teóricas aproximadas ou uso de valores aproximados para eventuais constantes físicas que sejam utilizadas (Vuolo, 1992); 
- Erros sistemáticos ambientais: são os erros provocados pelos efeitos do ambiente sobre a experiência. Fatores ambientais como temperatura, pressão, umidade, aceleração da gravidade, campo magnético terrestre, ondas de rádio, luz e outros podem introduzir erros nos resultados de uma medida (Raffo, 2000);

- Erros sistemáticos observacionais: são os erros provocados pela falha ou limitações do próprio observador. Os erros sistemáticos podem geralmente ser reduzidos ou podem ser feitas correções aos resultados finais. Entretanto, nem sempre isto é possível na prática. Por motivos diversos, pode ser que não seja possível reduzir ou estabelecer correções para erros sistemáticos. Estes tipos de erros são chamados de erros sistemáticos residuais (Vuolo, 1992).

Os erros grosseiros, também chamados erros ilegítimos, não são erros do ponto de vista da teoria de erros. São enganos que eventualmente podem ocorrer no procedimento de medida ou na realização de cálculos. Quando existir suspeita de que houve um engano em alguma leitura, esta leitura deve ser repetida ou eliminada do conjunto de dados (Vuolo, 1992).

\subsection{Análise de regressão linear}

Muitas vezes faz-se necessário encontrar uma expressão quantitativa, uma equação ou fórmula que revele uma relação numérica entre duas variáveis. Descobrir um modelo matemático que reflita a relação existente entre variáveis amostrais, pode significar a obtenção de estimativas, previsões e estudos de confiabilidade de trabalho experimentais (Hoffmann \& Vieira, 1989).

Segundo Vanni (1998), a análise de regressão é um método que procura estabelecer relações funcionais entre duas ou mais variáveis, isto é, procura encontrar um modelo que descreva da melhor e mais segura forma possível, o comportamento das variáveis que deseja analisar. A análise de regressão descreve a relação existente entre duas variáveis, a partir de várias 
(n) observações. É chamada de variável y a variável dependente, isto é, aquela cuja variação depende de outra variável (independente). A variável independente $\mathrm{x}$ corresponde à variável livre que assume qualquer valor natural na função $Y=f(x)$.

Construir um modelo de regressão linear de y sobre $x$ consiste em obter, a partir desses valores, uma reta que melhor represente a relação verdadeira entre essas variáveis. A determinação dos parâmetros dessa reta é denominada ajustamento. O processo de ajustamento deve partir da escolha da função através, da qual, os valores de x explicarão os de y (Charnet et al, 1999).

Para análise de regressão linear simples, é desejável a construção de um gráfico bidimensional denominado diagrama de dispersão. Cada valor é marcado em função das coordenadas de $x$ e y (Figura 32).

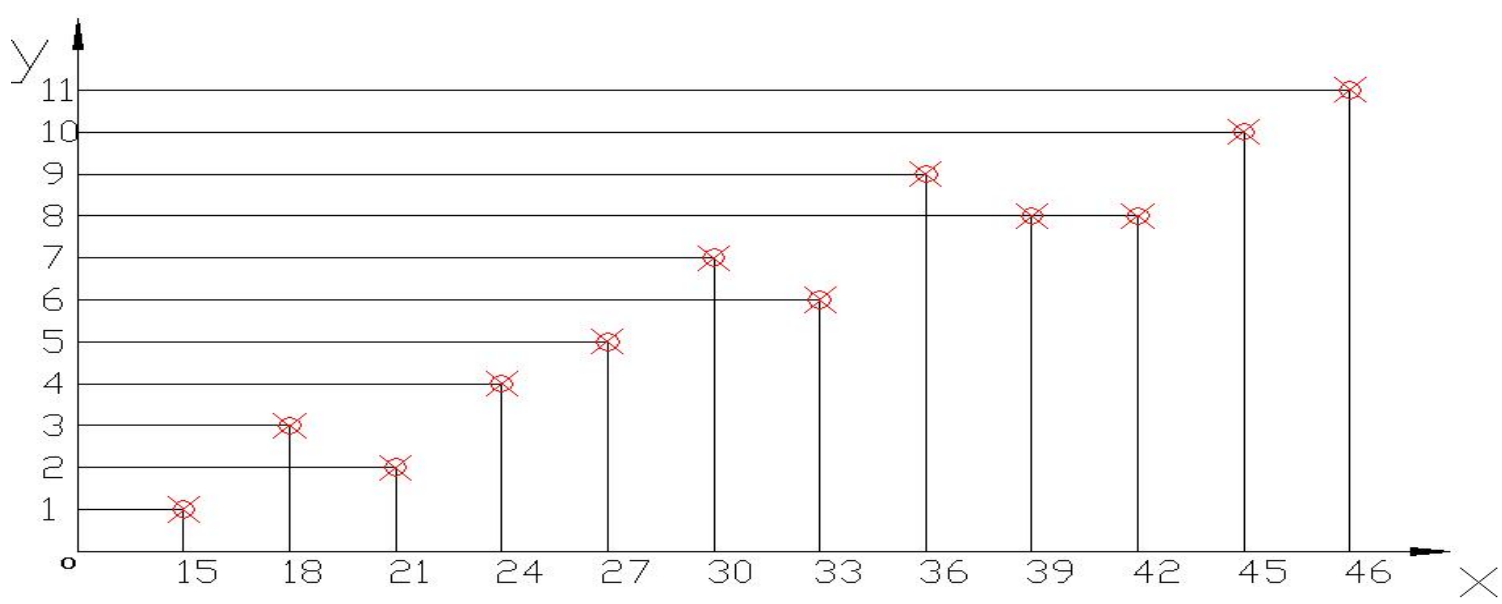

Figura 32 - Diagrama de dispersão (Martins, 2002)

O eixo vertical é chamado de ordenada e nele é registrada a variável dependente y. O eixo horizontal é chamado de abscissa e nele é registrada a variável independente $x$.

Segundo Martins (2002), observando o diagrama de dispersão podese ter uma idéia do tipo de relação entre duas variáveis. A natureza da relação 
pode tomar várias formas, desde uma simples relação linear até uma complicada função matemática. O modelo de regressão linear simples pode ser representado pela eq. (10).

$Y_{i}=\alpha+\beta X_{i}+e_{i}$

onde:

$\alpha=$ intercepto da reta;

$\beta=$ inclinação da reta;

$e_{i}=$ erro aleatório de y para a observação i.

Assim, a inclinação $\beta$ representa a mudança esperada de $Y$ por unidade de $\mathrm{X}$; isto é, representa a mudança de $\mathrm{Y}$ (tanto positiva quanto negativa) para uma particular unidade e $X$. Por outro lado, a representa o valor de $Y$ quando $X=0$, enquanto $e_{i}$ representa uma variável aleatória que descreve o erro de $Y$ para cada observação i.

Segundo Vanni (1998), torna-se necessário determinar, com base em uma amostra, a equação de regressão linear simples que melhor se ajuste aos dados amostrais. Isto é, encontrar os coeficientes da reta eq. (11).

$Y_{i}=a+b X_{i}$

onde:

$Y_{i}=0$ valor de previsão de $Y$ para uma observação $X_{i}$;

$\mathrm{X}_{\mathrm{i}}=\mathrm{O}$ valor de $\mathrm{X}$ para a observação $\mathrm{i}$;

$a=0$ estimador de $\alpha$;

$b=o$ estimador de $\beta$.

A reta ajustada é determinada pelos valores dos parâmetros a e b, de modo que a reta se ajuste ao conjunto de pontos amostrados. O método mais utilizado para estimar os valores desses parâmetros de uma forma eficaz é o 
Método dos Mínimos Quadrados. A reta será representativa dos pontos obtidos se a soma dos quadrados dos desvios for a menor possível, portanto mínima (Martin, 2002).

A partir do registro num diagrama, de uma série de pares ordenados $(\mathrm{x}, \mathrm{y})$, observa-se que através desses pontos poderá ser construída uma reta que reflita a tendência desses pontos (Figura 33).

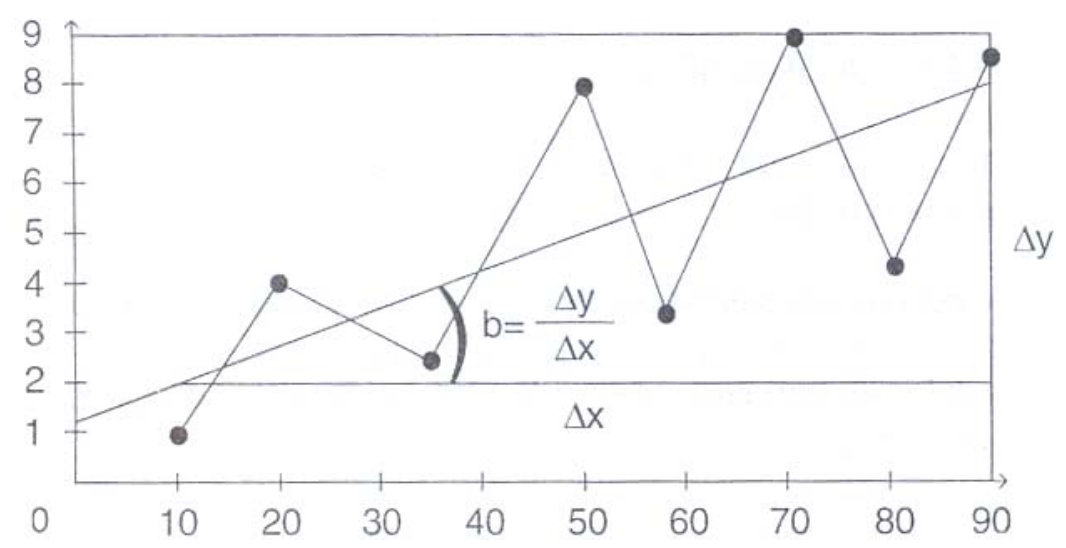

Figura 33 - Reta de tendência dos pontos amostrais (Vanni, 1998)

Com o objetivo de avaliar a qualidade do ajuste da reta aos pontos observados busca-se observar o resultado fornecido pelo coeficiente de determinação $\left(R^{2}\right)$ também chamado de poder explicativo da regressão. Seu valor fornece a proporção da variação total da variável y explicada pela variável x através da função ajustada (Charnet et al, 1999). A equação matemática de $R^{2}$ pode ser expressa pela eq. (12):

$$
R^{2}=\frac{b^{2}\left(\sum x^{2}-\frac{\left(\sum x\right)^{2}}{N}\right)}{\left(\sum y^{2}-\frac{\left(\sum y\right)^{2}}{N}\right)}
$$

onde:

$\mathrm{N}=$ número de variáveis amostrais;

$b=o$ estimador de $\beta$; 
$\mathrm{x}=\mathrm{o}$ valor de $\mathrm{X}$ para a observação $\mathrm{i}$;

$y=0$ valor de previsão de $Y$ para uma observação $X$.

Quando $R^{2}=0$, a variação explicada de y é zero, a reta ajustada é paralela ao eixo da variável $x$. Se $R^{2}=1$, a reta ajustada explica toda a variação de $y$. assim sendo, quanto mais próximo da unidade estiver o valor de $R^{2}$, melhor a qualidade do ajuste da função aos pontos do diagrama de dispersão. E quanto mais próximo de zero, pior será a qualidade do ajuste. O coeficiente de determinação $R^{2}$ pode ser interpretado pelo sentido relativo quando assumir valores entre 0 e 1 . Depois de multiplicado por 100 revela um percentual de ajustamento. Normalmente um ajustamento entre 65 e $75 \%$ pode ser considerado regular; entre 75 e $85 \%$ pode ser considerado bom e acima de $85 \%$ deve ser considerado ótimo. Abaixo de $60 \%$ demonstra que a variável independente x não explica com segurança a variação de y (Vanni, 1998). 


\section{MATERIAL E MÉTODOS}

\subsection{Material}

\subsubsection{Localização da área de estudo}

A área de estudo está situada no município de Piracicaba, Estado de São Paulo, compreendida entre os paralelos $22^{\circ} 40^{\prime} 38^{\prime \prime} \mathrm{S}$ e $22^{\circ} 42^{\prime} 30^{\prime \prime} \mathrm{S}$ e os meridianos $47^{\circ} 41^{\prime} 15^{\prime \prime} \mathrm{W}$ e $47^{\circ} 45^{\prime} 00^{\prime} \mathrm{W}$. Insere-se na região formada pela articulação da folha cartográfica de Santa Terezinha do Piracicaba, do Instituto de Geografia e Cartografia do Estado de São Paulo (IGCE 1979), na escala $1 / 10.000$. Possui área de aproximadamente $22 \mathrm{~km}^{2}$, com declives variáveis, apresenta culturas de cana-de-açúcar, pastagens, matas ciliares e perímetro urbano, conforme detalhado na Figura 34.

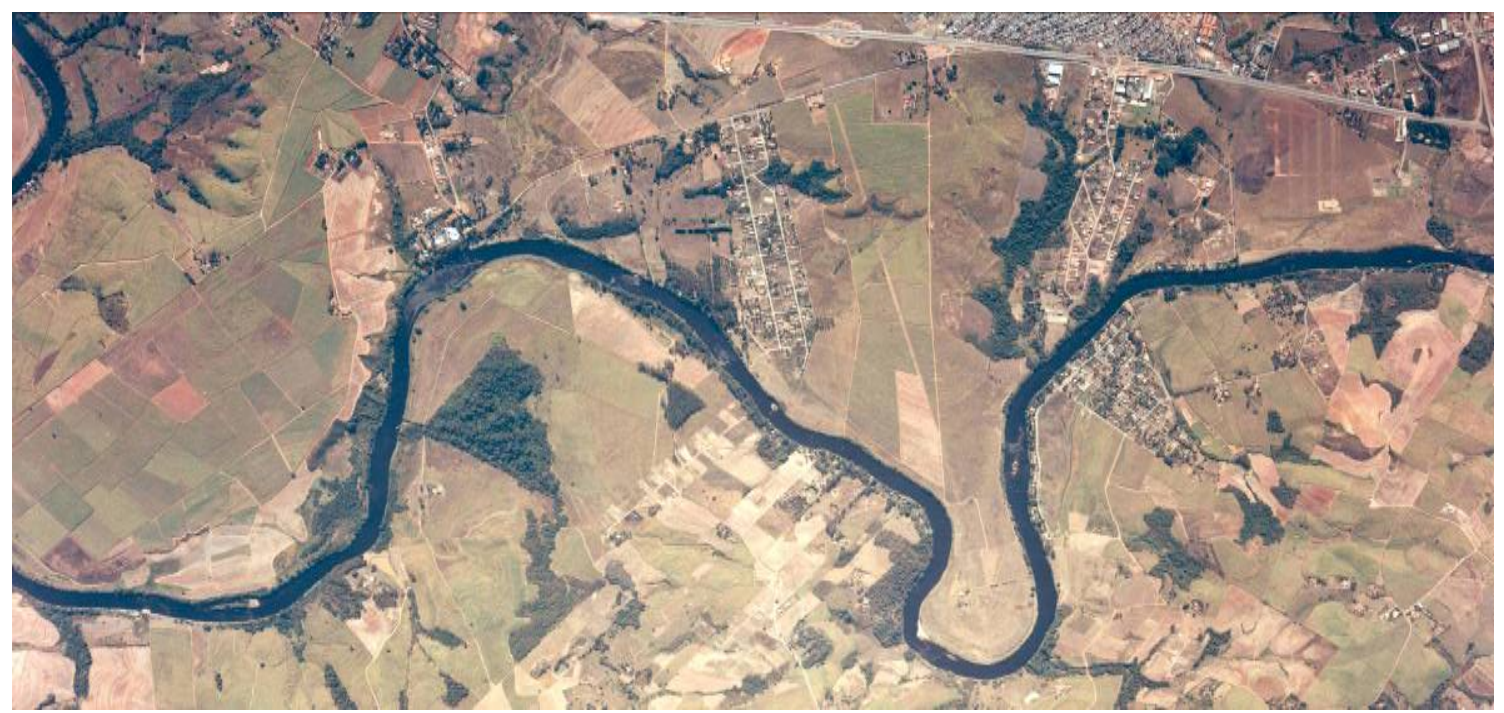

Figura 34 - Fotografia aérea do local de estudo 


\subsubsection{Equipamentos utilizados}

Para o processamento e análise dos dados, foi utilizado um microcomputador Pentium IV de $2.5 \mathrm{GHz}$, com $300 \mathrm{MB}$ de memória RAM, HD de $40 \mathrm{~GB}$ e placa de vídeo onboard de $8 \mathrm{MB}$, contendo, instalados, os programas necessários para o desenvolvimento e processamento dos dados.

Para aquisição de imagens no formato digital, utilizou-se um scanner HP ScanJet 5200 C.

\subsubsection{Software de base}

- AutoCAD R14 - Software gráfico desenvolvido pela Autodesk, específico para desenvolvimento de desenhos e projetos de Engenharia. Por ser executado dentro do ambiente Windows, possibilita a utilização dos recursos deste ambiente, como o ClipBord, o que facilita a importação e exportação de imagens.

- Adobe Photoshop 5.0 - Produto desenvolvido pelo Adobe Systems Incorporated. Programa de computação gráfica destinado para tratamento digital de imagem.

- Java 1.2 - Produto desenvolvido pela Sun Microsystems. É uma linguagem de programação para o desenvolvimento de software, que pode ser operado através da Internet, em redes internas ou em computadores pessoais. Uma vantagem significativa desta linguagem é o fato de permitir a comunicação com o usuário através dos browsers ou softwares de navegação de Internet, podendo incluir o código Java dentro do código HTML.

- Surfer 6.01 - Produto desenvolvido pelo Golden Software. Programa utilizado para a confecção de mapas de variáveis a partir de dados espacialmente distribuídos.

- Sistema Spring - Produto desenvolvido pelo Instituto Nacional de

Pesquisas Espaciais - INPE. É um sistema de geoprocessamento voltado à 
coleta e tratamento de informações espaciais, além da geração de saídas na forma de mapas convencionais, relatórios, arquivos digitais, e outros, devendo prover recursos para armazenamento, gerenciamento, manipulação e análise de dados. O sistema Spring constitui-se de três aplicativos ou programas executáveis, o "Impima" - utilizado para leitura de imagens e conversão para o formato GRIB, o "Spring"- programa principal do sistema em que serão modelados e processados os dados e o "Scarta"- este programa permite a elaboração de cartas a partir de dados previamente tratados no programa.

\subsubsection{Documentação cartográfica}

Como base cartográfica utilizou-se a carta Santa Terezinha do Piracicaba, do Instituto de Geografia e Cartografia do Estado de São Paulo (IGCE 1979) articulação SF-23-Y-A-IV-2-SO-C na escala 1/10.000, baseada em fotografias aéreas obtidas em 1978. Essa carta apresenta curvas de nível de 5 em 5 metros.

\subsubsection{Fotografia aérea}

A fotografia aérea utilizada para este projeto foi fornecida pela Secretaria Municipal de Trânsito e Transportes.

\subsection{Métodos}

No desenvolvimento do projeto foram utilizadas diferentes metodologias com o propósito de atingir aos objetivos definidos na proposta da dissertação. Todas estas metodologias foram intercalando-se e mudando ao longo do tempo como resultado da evolução tecnológica durante o período de desenvolvimento do trabalho, e também, como conseqüência dos 
aprimoramentos e das mudanças necessárias no processo da pesquisa. Porém, foram estabelecidas cinco etapas de trabalho:

$1^{\text {a }}$ etapa: Criação do mapa de fatiamento;

$2^{\mathrm{a}}$ etapa: Software I, georreferenciamento da fotografia aérea e do mapa de fatiamento;

$3^{a}$ etapa: Software II, criação de bando de dados do mapa de fatiamento;

$4^{\text {a }}$ etapa: Software III, vinculação do banco de dados a fotografia aérea;

$5^{\text {a }}$ etapa: Teste estatístico, estudo de confiabilidade dos resultados.

\subsubsection{Criação do mapa de fatiamento}

$\mathrm{Na}$ etapa inicial da pesquisa buscou-se criar um mapa de fatiamento através da digitalização das curvas de nível da carta topográfica, que se apresenta em formato matricial.

A digitalização se procedeu através da tela do monitor de vídeo do computador. As curvas de nível têm um intervalo de desnível de 5 metros, sendo a menor cota 460 e a maior cota 545. O software utilizado para digitalização foi o AutoCAD R14.

Sabendo-se que a forma de digitalização de curvas de nível em intervalos constantes de pontos é muito demorada, buscou-se diminuir o tempo de digitalização das curvas através da seguinte técnica de coleta de pontos:

a) quando a curva de nível apresentar pouca curvatura, ou seja, se comportar semelhante a uma "reta", serão digitalizado somente dois pontos. No início (ponto 1) e no fim (ponto 2) do percurso da curva de nível. (Figura 35). 


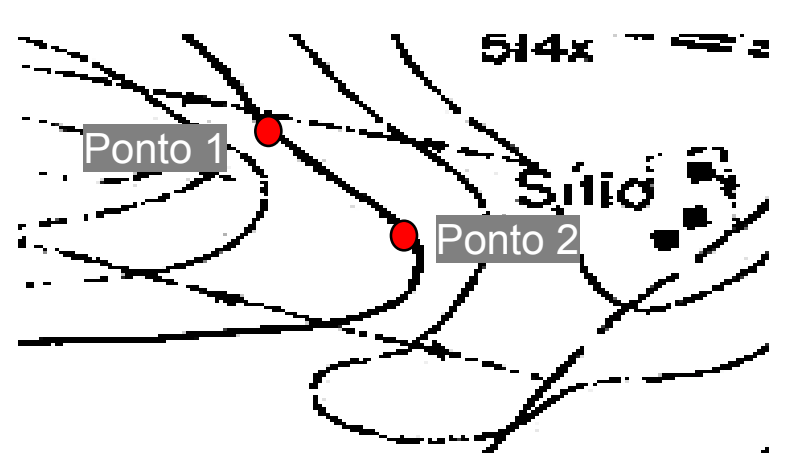

Figura 35 - Método de digitalização de curvas de nível com pouca curvatura

b) quando a curva de nível apresentar muita curvatura será digitalizado três pontos. No início (ponto 3), meio (ponto 4) e fim (ponto 5) do percurso da curva de nível (Figura 36).

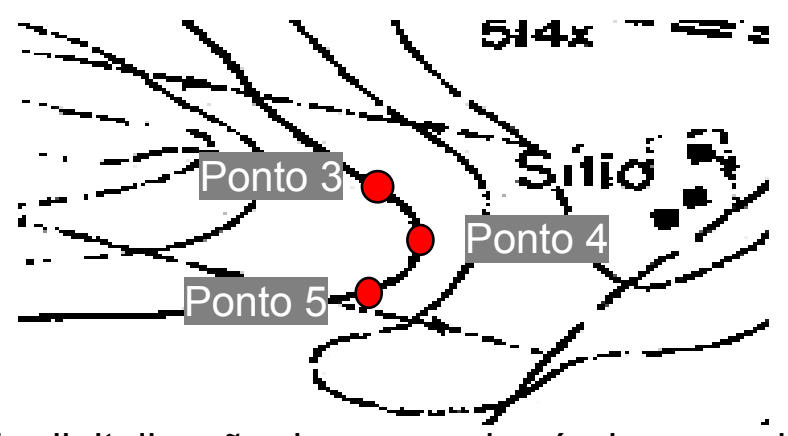

Figura 36 - Método de digitalização de curvas de nível com müita curvatura

No arquivo de digitalização, em formato dxf, foram armazenados dados de $\mathrm{X}, \mathrm{Y}$ e $\mathrm{Z}$. Os valores de $\mathrm{X}$ e $\mathrm{Y}$ são as coordenadas UTM de cada ponto da curva de nível e $Z$ corresponde à altitude.

Para geração do mapa de fatiamento, foram analisadas duas metodologias. Usando diferentes recursos computacionais, softwares e interpoladores matemáticos.

A primeira metodologia consiste na utilização do software Spring para a criação do mapa de fatiamento, através de um MNT. Foram testados os dois recursos de modelagem (grade retangular e triangular) para modelar a área de estudo. Definiu-se que as fatias deveriam se apresentar em intervalos de 5 
metros, igual ao desnível das curvas de nível, buscando manter as características originais da carta digitalizada. Criando assim, as seguintes fatias: $455-460,460-465, \ldots, 535-540,540-545$.

Em modelagem por grade triangular os vértices do triângulo são os pontos amostrados. Porém, não é possível a sua representação de forma matricial (mapa de fatiamento). Devido a este problema operacional, usa-se um método de geração de grade retangular através de uma grade triangular conhecido como "método híbrido". Desse modo às informações do terreno, modeladas por uma grade triangular, podem ser analisados em forma de mapas. O processo de conversão utiliza o ajuste de uma superfície a cada triângulo. A grade criada na modelagem híbrida é de $10 \times 10$.

Em modelagem por grade retangular os pontos amostrados são utilizados para calcular o valor aproximado de altitude nos locais não amostrados. A grade criada é de $10 \times 10$. Foram testados todos os interpoladores do software: vizinho mais próximo, média simples, média ponderada, média ponderada por quadrante e média por cota e por quadrante.

A Figura 37 demonstra a grade do MNT juntamente com o mapa de fatiamento produzido pelo conjunto de grade.

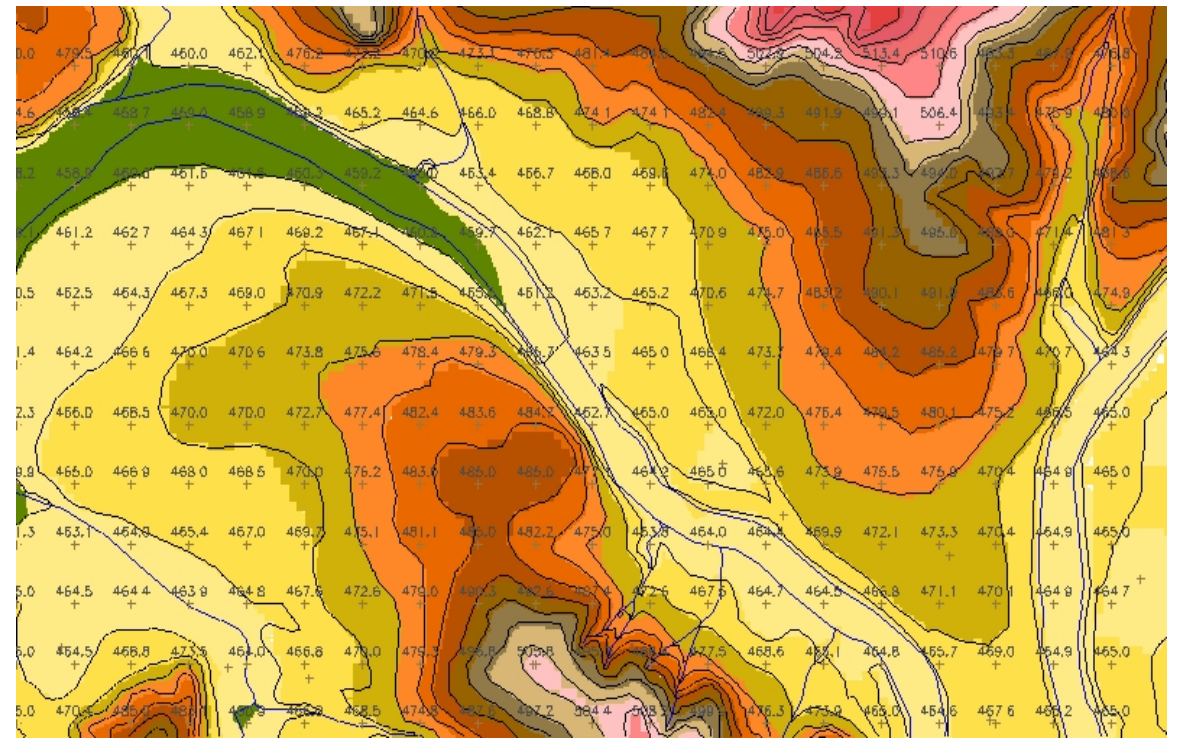

Figura 37 - Exemplo de mapa de fatiamento produzido do software Spring 
A segunda metodologia consiste na criação do mapa de fatiamento pelo próprio AutoCAD. Nesta etapa, foi utilizado a ferramena "Hachura" para criar o mapa de fatiamento, ou seja, inserir cores no intervalo das curvas de nível (Figura 38). Sendo assim, produziu-se o mapa sem precisar criar um MNT. O intervalo das fatias é o mesmo apresentado no método anterior.

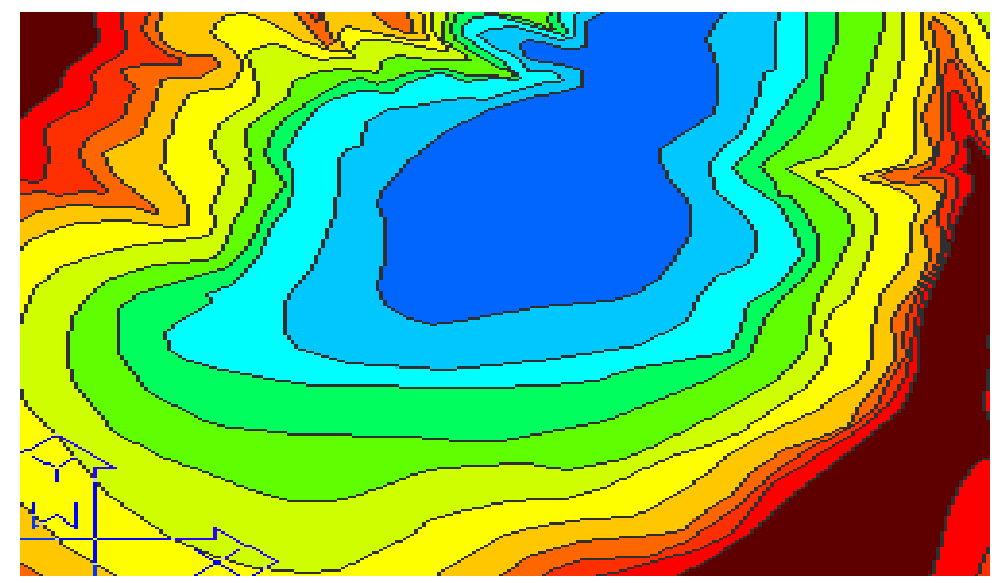

Figura 38 - Parte do mapa de fatiamento produzido pelo software AutoCAD

\subsubsection{Software I, georreferenciamento da fotografia aérea e do mapa de fatiamento}

Utilizou-se o modelo matemático das equações de colinearidade, para obtenção das coordenadas topográficas dos elementos existentes na fotografia aérea e no mapa de fatiamento. A implementação deste procedimento levou ao desenvolvimento de um software, produzido em linguagem Java, funcional em plataforma Pentium e opera sobre o sistema operacional Windows. Denominado de "Software I".

Foram selecionados seis pontos de controle na fotografia aérea (Figura 39) e no mapa de fatiamento, homólogos a carta topográfica. A Figura 
40 demonstra as coordenadas UTM e as coordenadas de tela ( $\mathrm{u}$ e v), do computador, dos pontos de controle da fotografia aérea.

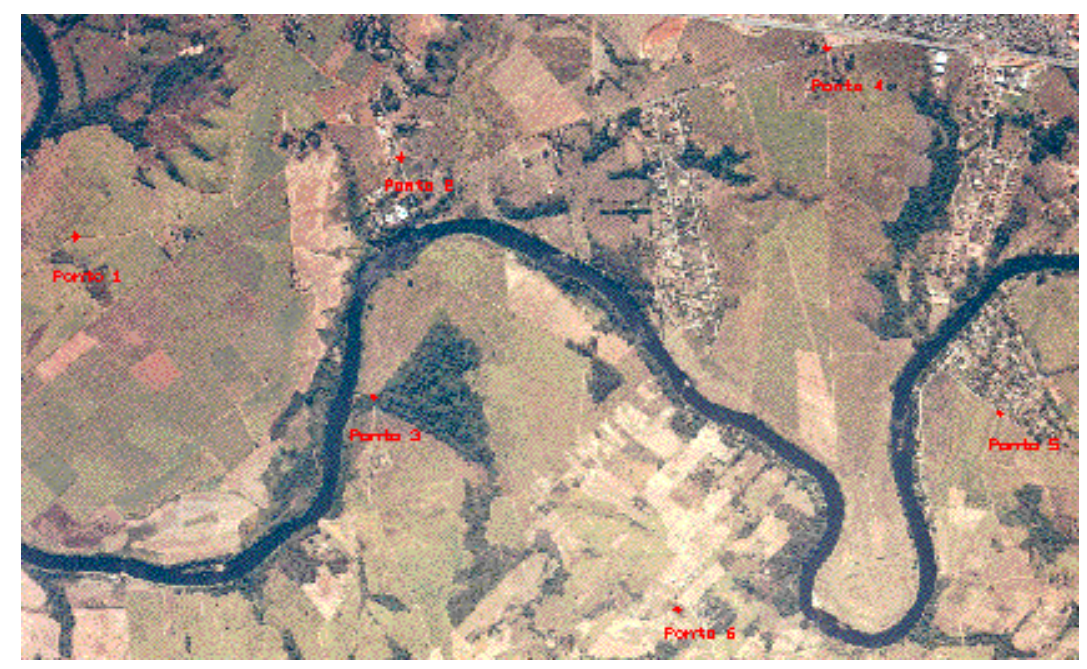

Figura 39 - Representação dos pontos de controle na fotografia aérea

\begin{tabular}{|l|r|r|r|r|}
\hline Numeração & $\begin{array}{c}\text { Coordenada } \\
\text { UTM E(m) }\end{array}$ & $\begin{array}{c}\text { Coordenada } \\
\text { UTM N(m) }\end{array}$ & $\begin{array}{c}\text { Coordenada } \\
\text { Pixel u }\end{array}$ & $\begin{array}{c}\text { Coordenada } \\
\text { Pixel v }\end{array}$ \\
\hline Ponto1 & $217.726,28$ & $7.488 .386,67$ & 174 & 419 \\
\hline Ponto2 & $219.342,00$ & $7.488 .806,75$ & 246 & 439 \\
\hline Ponto3 & $219.205,88$ & $7.487 .553,93$ & 240 & 381 \\
\hline Ponto4 & $221.433,14$ & $7.489 .383,59$ & 340 & 466 \\
\hline Ponto5 & $222.320,52$ & $7.487 .511,21$ & 380 & 379 \\
\hline Ponto6 & $220.711,29$ & $7.486 .441,48$ & 307 & 332 \\
\hline
\end{tabular}

Figura 40 - Coordenadas dos pontos de controle

A partir das equações de colinearidade (eq. 8), determinou-se os sete parâmetros de orientação $\left(E_{0}, N_{0}, Z_{0}, \varphi, \omega\right.$, $\kappa$ e focal da câmara) das imagens (fotografia aérea e mapa de fatiamento) utilizando os seis pontos de controle.

Como os pontos de controle foram identificados nas imagens, são conhecidas suas coordenadas pixel ( $u$ e $v$ ). A partir das coordenadas do ponto principal $\left(x_{C p}, y_{C p}\right)$, centro das imagens, chegou-se às suas coordenadas no sistema das imagens $\left(x_{p}, y_{p}\right)$ (Figura 41). 


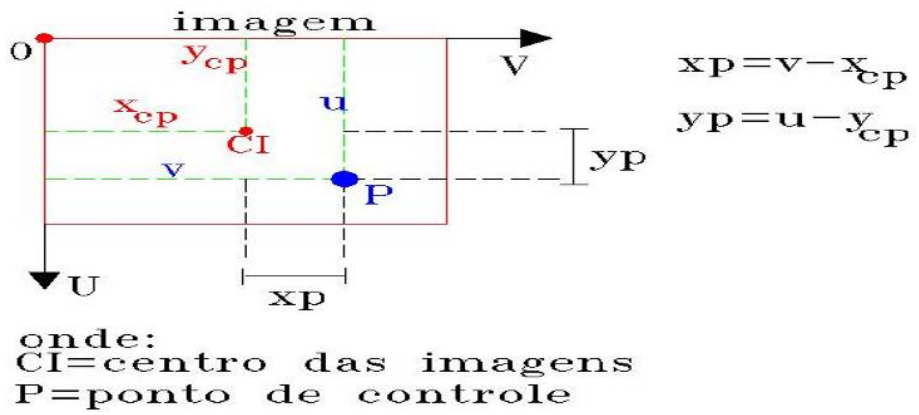

Figura 41 - Representação do processo de cálculo das coordenadas do ponto $\mathrm{P}$ no sistema de coordenadas da imagem

Como dados, também se encontram disponíveis as coordenadas tridimensionais dos seis pontos de controle $\left(E_{1}, N_{1}, Z_{1}, E_{2}, N_{2}, Z_{2}, \ldots, E_{5}, N_{5}, Z_{5}\right.$, $\left.E_{6}, N_{6}, Z_{6}\right)$.

Como os movimentos de rotação da câmara $(\varphi, \omega)$ são praticamente inexistentes, devido à existência de um sistema de nivelamento no eixo $\mathrm{X}$ e $\mathrm{Y}$ da câmara fotográfica, considerou-se nulo o ângulo de rotação. Porem, ainda prevaleceu o parâmetro "к" para ser calculado.

Com todos estes valores conhecidos, restou-se apenas determinas os parâmetros de orientação. Já que, com estes parâmetros, é possível calcular a partir das equações de colinearidade as coordenadas UTM de pontos nas imagens.

\subsubsection{Software II, criação de bando de dados do mapa de fatiamento}

Software desenvolvido em linguagem Java, funcional em plataforma Pentium e opera sobre o sistema operacional Windows. Tem como objetivo calcular a altitude de todos os pixels da imagem do mapa de fatiamento. A implementação deste procedimento levou ao desenvolvimento de dois algoritmos: 
a) Varredura de cores: tem o objetivo específico de identificar todas as cores existentes no mapa de fatiamento. A origem do sistema de varredura de cores $\left(P_{00}\right)$ é o canto superior esquerdo da imagem (Figura 42). A varredura se procede da esquerda para a direita.

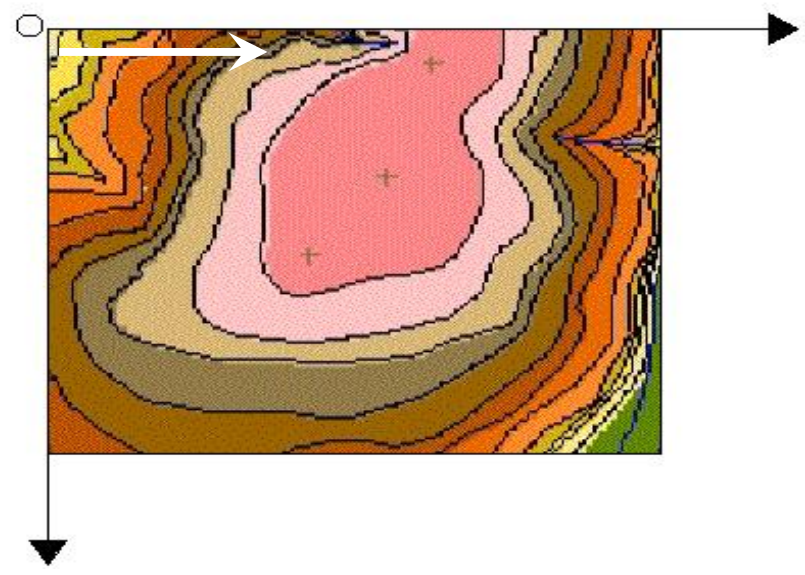

Figura 42 - Origem do processo de varredura de cores dos pixels da imagem

A Figura 43 representa o algoritmo de varredura de cores do mapa de fatiamento.

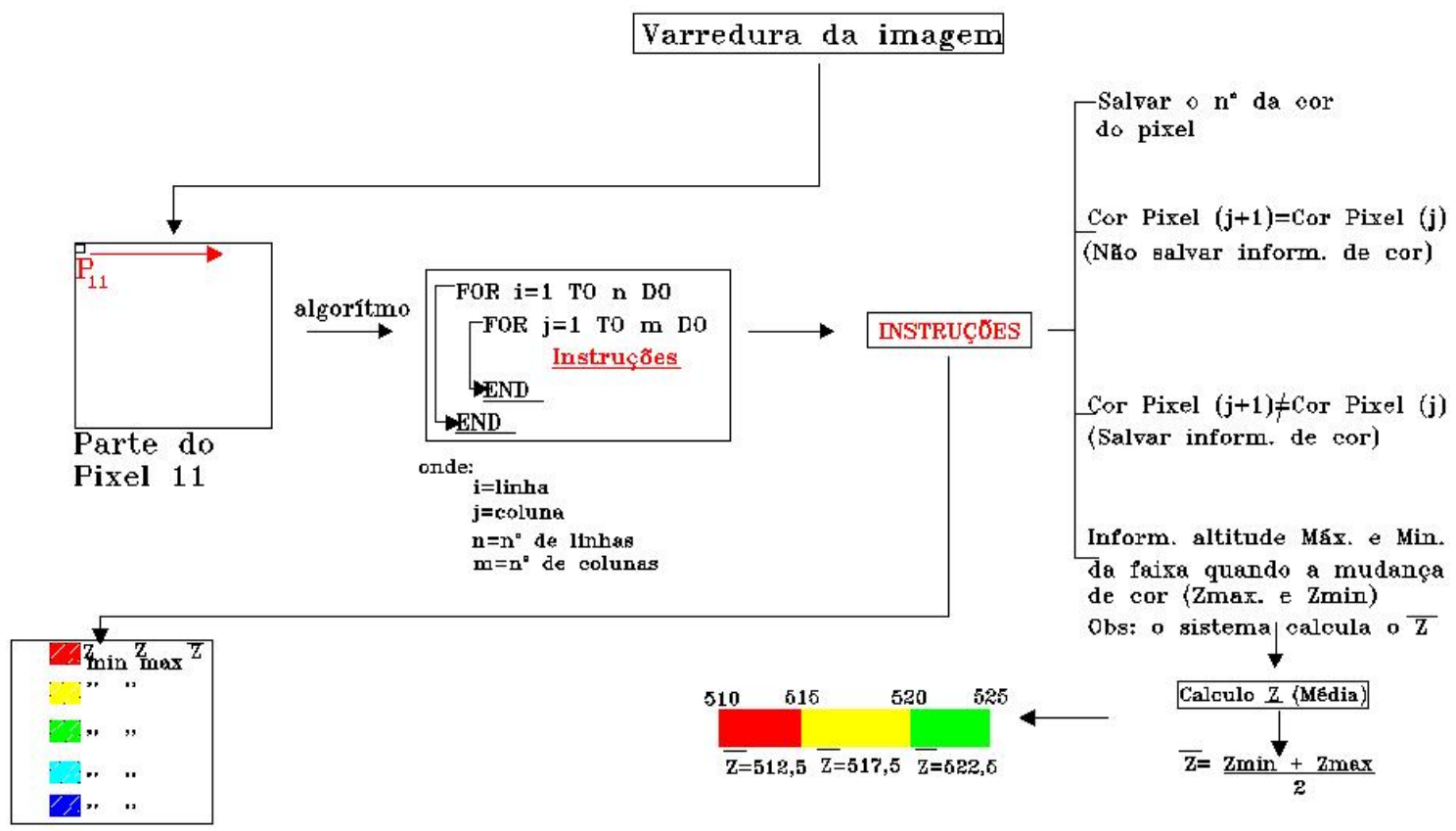

Banco de dados

Figura 43 - Representação do algoritmo de varredura de cores 
O software inicia a varredura no Pixel $\left(P_{11}\right)$ da matriz de cores. Nesta varredura é feita a identificação dos números de cor dos pixels, e a informação é salva em um bando de dados (banco de dados de cores). A cada cor é associado, manualmente, um intervalo de altitude $\left(Z_{\text {máx. }}\right.$ e $Z_{\text {min. }}$ ), durante a varredura, que representa a altitude máxima e mínima de cada fatia de cor. Logo após, calcula-se a média altimétrica das faixas e salvam-se as informações no banco de dados do software. Durante a varredura são identificadas cores iguais aos já salvos no banco de dados, o software discrimina a informação.

b) Cálculo de altitude dos pixels: tem o objetivo específico de calcular a altitude de cada pixel da imagem do mapa de fatiamento e salvar as informações em um banco de dados (banco de dados do mapa de fatiamento). Este banco de dados será vinculado a fotografia aérea, utilizando o Software III. Dessa forma, será possível informar a altitude de um ponto na fotografia.

Durante o desenvolvimento do projeto foram identificadas quadro situações de ambiente de varredura da imagem para cálculo de altitude. Estas situações foram classificadas e caracterizadas devido às condições e configurações de varredura do software e pelo comportamento topográfico da área de estudo.

- Situação I, borda esquerda da imagem: nesta situação é calculada a altitude dos pixels situados entre a faixa vermelha da imagem (Figura 44).

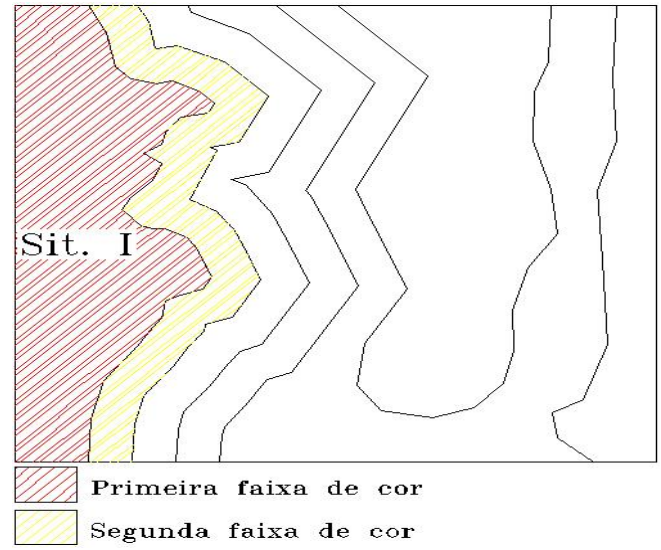

Figura 44 - Visualização da faixa de cor de varredura da situação I 
Com intenção de descobrir o comportamento topográfico (aclive ou declive) da faixa de cor analisada, o software faz uma busca no banco de dados de cores, criado pelo primeiro algoritmo. Buscando informações de altitude média da primeira $\left(Z_{\mathrm{m} 1}\right.$, cor vermelha) e segunda $\left(Z_{\mathrm{m} 2}\right.$, cor amarela) faixa de cor. onde:

$$
\begin{aligned}
& Z_{\mathrm{m} 1}>Z_{\mathrm{m} 2}=\text { terreno em declive; } \\
& Z_{\mathrm{m} 1}<Z_{\mathrm{m} 2}=\text { terreno em aclive. }
\end{aligned}
$$

Quando o terreno estiver em declive, considerou-se a borda esquerda da imagem como valor máximo de altitude da faixa de cor $\left(Z_{\text {máx. }}\right)$. Utilizou-se a eq. (13) para calcular a altitude dos pixels nesta situação.

$$
Z_{i j}=Z_{i j(\text { máx })}-\frac{\Delta Z}{X} * X^{\prime \prime} ;
$$

onde:

$\mathrm{Z}_{\mathrm{ij}}=$ altitude calculada;

$Z_{\mathrm{ij} \text { (máx. })}=$ altitude máxima;

$\Delta Z=$ diferença de nível;

$X=$ total de pixels da linha de varredura da primeira faixa de cor;

X"= número de pixels entre a borda esquerda da imagem e o pixel em questão.

Quando o terreno estiver em aclive, considerou-se a borda esquerda da imagem como valor mínimo de altitude da faixa de cor $\left(Z_{\text {min. }}\right)$. Utilizou-se a eq. (14) para calcular a altitude dos pixels.

$Z_{i j}=Z_{i j(\min )}+\frac{\Delta Z}{X} * X^{\prime \prime} ;$

onde:

$Z_{\mathrm{ij}}=$ altitude calculada;

$Z_{\mathrm{ij}(\text { min. })}=$ altitude mínima;

$\Delta Z=$ diferença de nível; 
$X=$ total de pixels da linha de varredura da primeira faixa de cor;

X"= número de pixels entre a borda esquerda da imagem e o pixel em questão.

- Situação II, regiões intermediárias da imagem: nesta situação foi calculada a altitude dos pixels situados nas regiões intermediárias da imagem, desconsiderando os locais que apresentam comportamentos topográficos semelhante a vales e cristas e regiões de faixas de cores junto à borda direita da imagem (Figura 45).

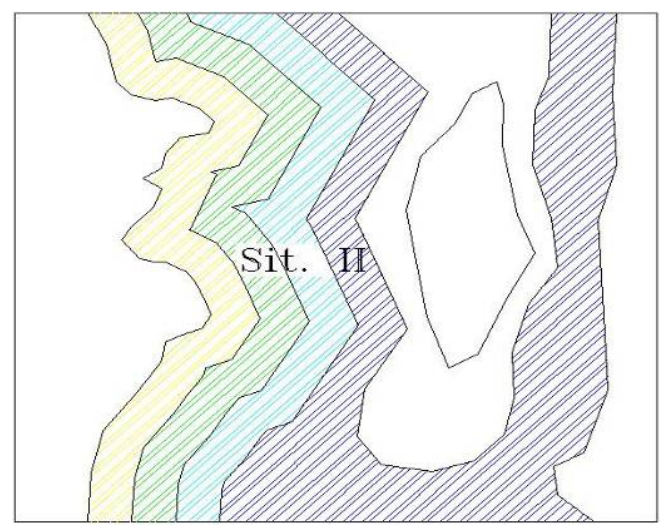

Figura 45 - Visualização das faixas de cores de varredura pela situação II

Nesta situação, utilizou-se as mesmas equações e os mesmos métodos da situação anterior para cálculo de altitude e determinação de comportamentos topográficos. O fator diferencial é que, neste método, calculouse a altitude de quase todos os pixels da imagem, utilizando os extremos das faixas de cores como locais que apresentam altitude máxima $\left(Z_{\text {máx. }}\right)$ e mínima $\left(Z_{\text {min. }}\right)$. Enquanto, o método anterior calcula a altitude dos pixels adotando a borda esquerda da imagem como local que demonstra altitude máxima ou mínima, dependendo do comportamento topográfico.

- Situação III, regiões de vales e cristas: nesta situação foi calculada a altitude dos pixels situados nas regiões de vales e cristas da imagem (Figura 46). 


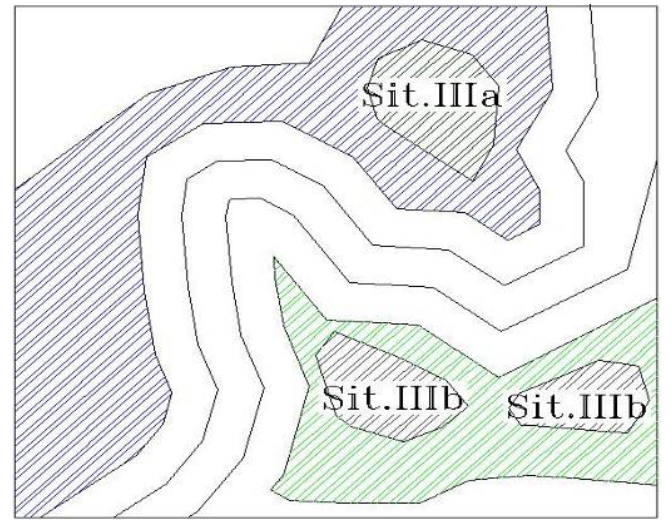

Figura 46 - Visualização das faixas de cores de varredura pela situação III

Quando a média de altitude $Z_{m 1}$ for maior que $Z_{m 2}$, representa uma região de vale (sit. $\mathrm{III}_{\mathrm{A}}$ ). A Figura 47 representa a visão frontal de uma região de vale.

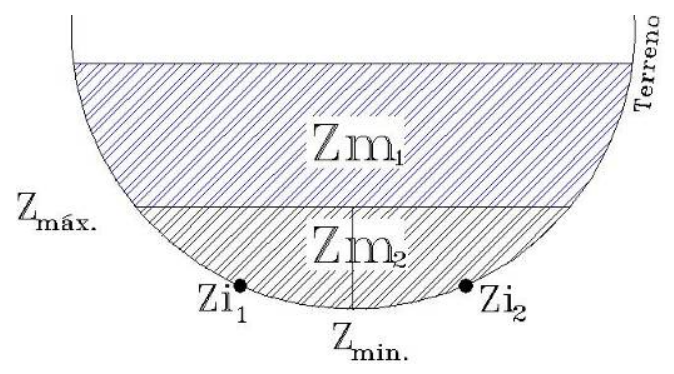

Figura 47 - Visão frontal de uma região de vale

Para calcular a altitudes dos pixels, considerou-se o fundo do vale como sendo o local de altitude mínima $\left(Z_{\text {min. }}\right)$. Utilizando a Figura 57 como exemplo, calculou-se as altitudes dos pontos $Z_{i 1}$ e $Z_{i 2}$ através das equações eq. (15) e eq. (16).

$Z_{i 1}=Z_{\text {máx. }}-\frac{\Delta Z}{X} / 2 * X^{\prime \prime} ;$

onde:

$\mathrm{Z}_{\mathrm{i} 1}=$ altitude calculada;

$Z_{\text {(máx.) }}=$ altitude máxima;

$\Delta Z=$ diferença de nível; 
$X=$ total de pixels da linha de varredura entre o $Z_{\text {máx. e o meio do vale; }}$ $X "=$ número de pixels entre $Z_{\text {máx. }}$ e o pixel em questão.

$$
Z_{i 2}=Z_{\text {min. }}-\frac{\Delta Z}{X} / 2 * X^{\prime \prime} ;
$$

onde:

$\mathrm{Z}_{\mathrm{i} 2}=$ altitude calculada;

$Z_{(\text {min. })}=$ altitude mínima;

$\Delta Z=$ diferença de nível;

$X=$ total de pixels da linha de varredura entre o meio do pixel e o $Z_{\min }$;

X"= número de pixels entre o meio do vale e o pixel em questão.

Quando a média de altitude $Z_{\mathrm{m} 1}$ for menor que $Z_{\mathrm{m} 2}$, representa uma região de crista (sit. $\mathrm{III}_{\mathrm{B}}$ ). A Figura 48 representa a visão frontal de uma região de crista.

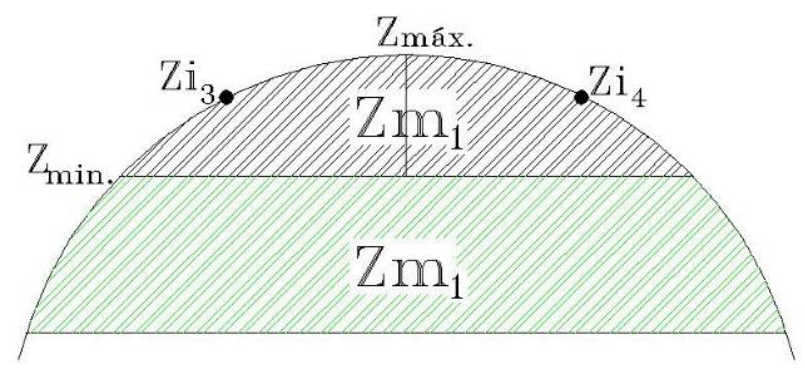

Figura 48 - Visão frontal de uma região de cristas.

Para calcular a altitudes dos pixels, considerou-se o fundo do vale como sendo o local de altitude máxima $\left(Z_{\text {máx. }}\right)$. Utilizando a Figura 54 como exemplo, calculou-se as altitudes dos pontos $Z_{i 3}$ e $Z_{i 4}$ através das equações eq. (17) e eq. (18).

$Z_{i 3}=Z_{\text {min. }}+\frac{\Delta Z}{X} / 2 * X^{\prime \prime}$;

onde:

$\mathrm{Z}_{\mathrm{i} 3}=$ altitude calculada; 
$Z_{\mathrm{j}(\min .)}=$ altitude mínima;

$\Delta Z$ = diferença de nível;

$X=$ total de pixels da linha de varredura;

$X "=$ número de pixels entre $Z_{\min }$. e o pixel em questão.

$$
Z_{i 4}=Z_{\text {máx. }}-\frac{\Delta Z}{X} / 2 * X^{\prime \prime} ;
$$

onde:

$\mathrm{Z}_{\mathrm{i} 4}=$ altitude calculada;

$Z_{(\text {máx.) }}=$ altitude máxima;

$\Delta Z=$ diferença de nível;

$X=$ total de pixels da linha de varredura;

$X "=$ número de pixels entre $Z_{\text {máx. }}$ e o pixel em questão.

- Situação IV, borda direita da imagem: nesta situação é calculada a altitude dos pixels, situados entre a faixa verde da imagem (Figura 49).

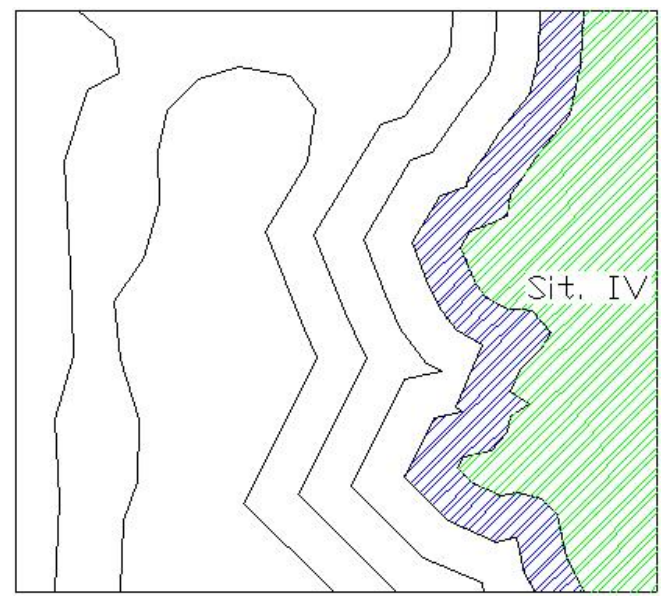

Figura 49 - Visualização da faixa de cor de varredura da situação IV

O comportamento topográfico (aclive ou declive) da faixa de cor analisada é identificado pela análise das informações de altitude média da primeira $\left(Z_{\mathrm{m} 1}\right.$, cor azul) e segunda $\left(Z_{\mathrm{m} 2}\right.$, cor verde) faixa de cor. 
onde:

$Z_{\mathrm{m} 1}>Z_{\mathrm{m} 2}=$ terreno em declive;

$Z_{\mathrm{m} 1}<Z_{\mathrm{m} 2}=$ terreno em aclive.

Quando o terreno estiver em declive, considerou-se a borda direita da imagem como valor mínimo de altitude da faixa de cor $\left(Z_{\text {min. }}\right)$. Utilizou-se a eq. (19) para calcular a altitude dos pixels nesta situação.

$Z_{i j}=Z_{i j(\text { máx })}-\frac{\Delta Z}{X} * X^{\prime \prime} ;$

onde:

$\mathrm{Z}_{\mathrm{ij}}=$ altitude calculada;

$Z_{\mathrm{ij}(\text { máx. })}=$ altitude máximo;

$\Delta Z=$ diferença de nível;

$X=$ total de pixels da linha de varredura entre o início da faixa de cor verde até a borda direita da imagem;

X"= número de pixels entre o início da faixa de cor verde até o pixel em questão.

Quando o terreno estiver em aclive, considerou-se a borda direita da imagem como valor máximo de altitude da faixa de cor $\left(Z_{\text {máx. }}\right)$. Utilizou-se a eq. (20) para calcular a altitude dos pixels.

$Z_{i j}=Z_{i j(m i n)}+\frac{\Delta Z}{X} * X^{\prime \prime} ;$

onde:

$Z_{\mathrm{ij}}=$ altitude calculada;

$Z_{\mathrm{ij}(\min .)}=$ altitude mínima;

$\Delta Z=$ diferença de nível;

$X=$ total de pixels da linha de varredura entre o início da faixa de cor verde até a borda direita da imagem; 
X"= número de pixels entre o início da faixa de cor verde até o pixel em questão.

\subsubsection{Software III, vinculação do banco de dados a fotografia aérea}

Software desenvolvido em linguagem Java, destinado a operar pela Internet. Funcional em plataforma Pentium e opera sobre o sistema operacional Windows. Tem como objetivo recuperar valores de coordenadas UTM e a variável altitude $(Z)$ a partir da indicação de um ponto sobre a fotografia aérea e gerar curvas de nível sobre ela. Isto somente é possível com a vinculação do banco de dados do mapa de fatiamento (produzido pelo Software II) a fotografia aérea (Figura 50).

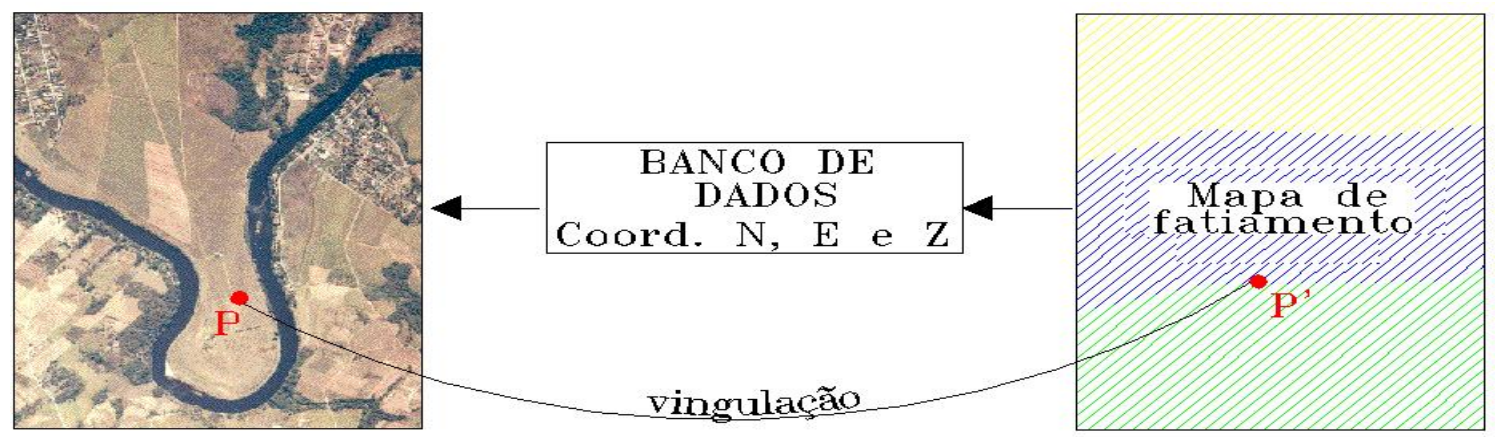

Figura 50 - Representação da vinculação do banco de dados a fotografia aérea

A vinculação é feita através do georreferenciamento das duas imagens. Ao clicar do mouse sobre a fotografia aérea teremos a informações das coordenadas UTM da fotografia. Logo em seguinda, o referido software fará uma busca no banco de dados do mapa de fatiamento, procurando o valor da variável altitude $(Z)$, correspondente a mesma coordenada UTM calculada na fotografia.

Foram criados quatro módulos (ferramentas), os quais apresentam as seguintes características: 
a) Existência de recurso para obtenção das coordenadas topográficas dos pontos da imagem, este processo pode ser denominado de "retificação virtual de imagem".

b) Existência de recurso para obtenção de altitude dos pontos da imagem, este processo é denominado de "informação de atributo".

c) Existência de recurso para criação automática de curva de nível sobre a fotografia aérea.

d) Existência de recurso para edição e criação de mapas de fatiamento.

O referido Software apresenta a possibilidade de visualização de diferentes tipos de imagens, desde fotografias aéreas convencionais até plantas topográficas, passando por imagens de satélite, todas elas previamente rasterizadas. A Figura 51 demonstra o algoritmo de desenvolvimento do software.

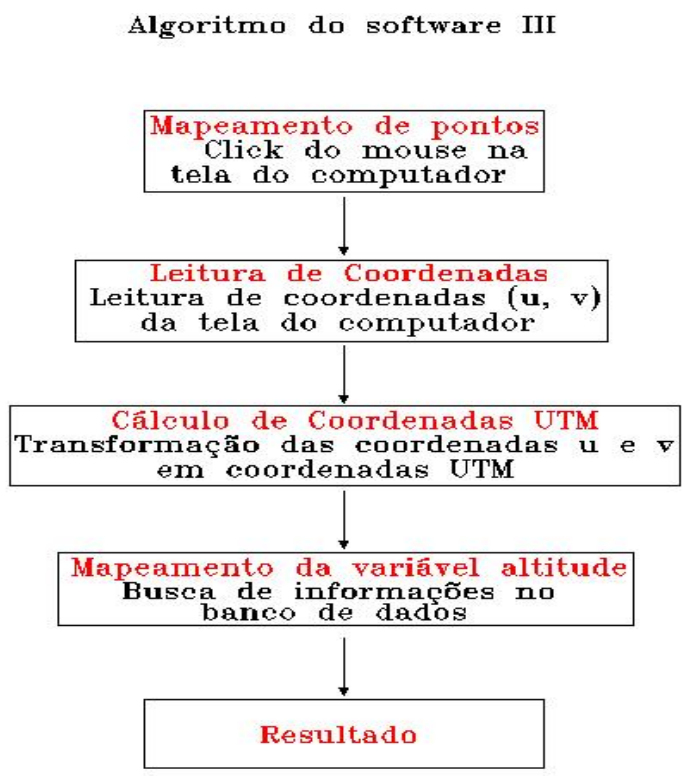

Figura 51 - Algoritmo do Software III

\subsubsection{Teste estatístico, estudo de confiabilidade}


A análise estatística foi realizada através da comparação dos dados obtidos com os pontos de controle de referência, pré-determinados na carta topográfica, com o resultado fornecido pelo software III.

Os testes de confiabilidade estão fundamentados na metodologia de Regressão Linear Simples e nas Normas Técnicas da Cartografia Nacional, citadas pelo Decreto № 89.817 de 20 de junho de 1984 .

$\mathrm{Na}$ Regressão Linear Simples, utilizou-se do Método dos Mínimos Quadrados para ajustamento da reta de regressão. Analisou-se assim, como uma variável dependente (pontos de controle de referência) é afetada por outra variável independente (pontos de análise). $\mathrm{Na}$ análise de regressão, foi comparados os resultados altimétricos fornecidos pelo software III para as coordenadas "E" e "N" dos pontos de controle de referência (PCR), levantados na carta topográfica. Foi observado o comportamento da reta de tendência que corta o $1^{\circ}$ quadrante do plano cartesiano, e também, foi analisado o coeficiente para a variável $X$, verificando o quanto a reta de tendência se aproxima de $45^{\circ}$. Observou-se o Coeficiente de Determinação $\left(R^{2}\right)$ que determinará a variação dos dados de pontos de analise (PA) em relação aos dados PCR. Adotou-se um nível de significância de 0,01, considerando que, se o fator de significância for menor de 0,01, então o método analisado será considerado válido e poderá ser aceito.

A qualidade das cartas elaboradas no país é avaliada utilizando-se as "Normas Técnicas da Cartografia Nacional". Nesta trabalho não é confeccionada uma nova carta, somente é transferida informação de uma carta topográfica para uma fotografia aérea, embora assim, não existindo normas de controle de qualidade, no caso que nos ocupa, foram adotadas e adaptadas as normas do decreto 89.817 de 20 de Junho de 1984. Segundo as "Normas Técnicas da Cartografia Nacional", as cartas, quanto a sua exatidão, devem obedecer ao Padrão de exatidão Cartográfica - PEC, sendo que noventa por cento dos pontos isolados de altitude, obtidos por interpolação de curvas-denível, quanto testados, não deverão apresentar erro superior ao PEC - 
Altimétrico. O valor do PEC esta organizado por classes, variando as exigências de qualidade, desde um máximo, Classe $A$, até um mínimo, Classe $C$. Para a Classe A, o PEC é metade da eqüidistância entre as curvas-de-nível, sendo de um terço desta eqüidistância o Erro-Padrão correspondente. O denominado Erro Padrão corresponde ao Desvio-Padrão do conjunto de análise. 


\section{RESULTADOS E DISCUSSÃO}

\subsection{Mapa de fatiamento}

\subsubsection{Primeira metodologia, criação do mapa de fatiamento pelo software Spring.}

Como foi indicado anteriormente, neste projeto, o software Spring apresenta três recursos de modelagem: o retangular, triangular e o híbrido.

Adotou-se como forma padrão de resultado, o mapa de fatiamento que apresentasse a distribuição de suas fatias com cores o mais próximo possível da distribuição das curvas de nível. O recurso que melhor se apresentou foi o método híbrido (Figura 52).

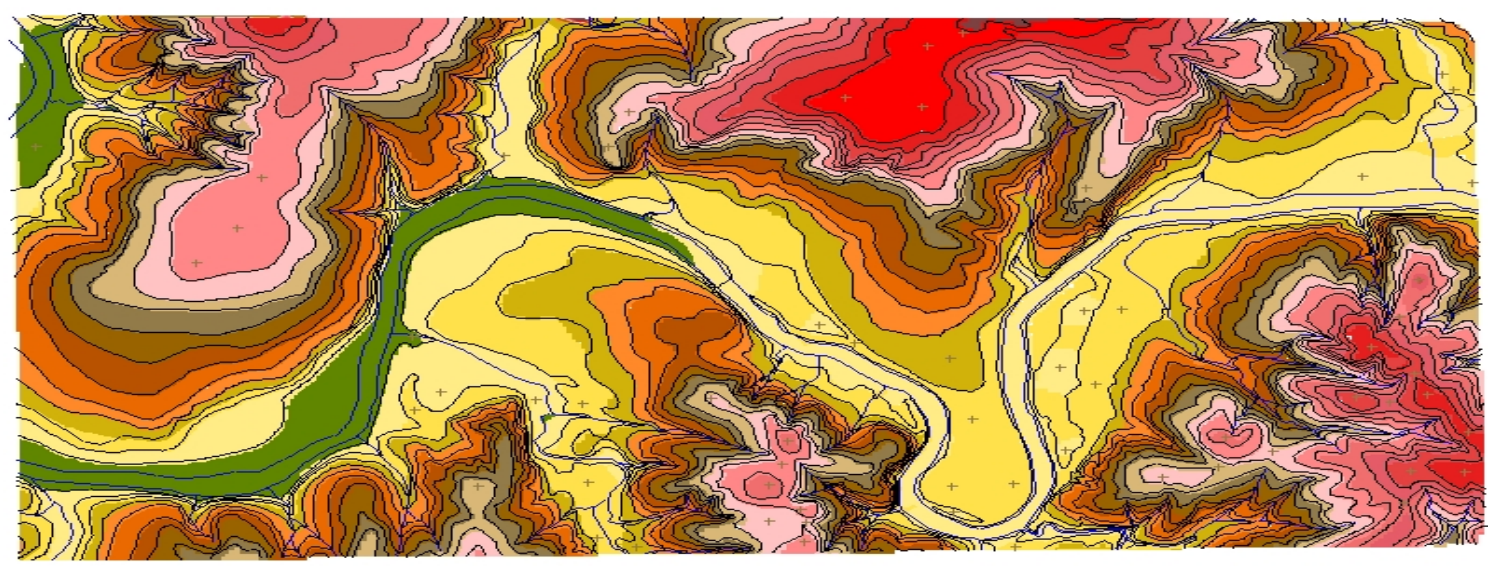

Figura 52 - Mapa de fatiamento produzido pelo método híbrido 
Apesar de sua boa distribuição de cores, o mapa apresentou alguns problemas, devido aos erros de interpolação, que poderiam comprometer os resultados deste projeto. Por este motivo, o mapa de fatiamento produzido por este método não foi utilizado.

A seguir, são analisados os erros visualizados no mapa de fatiamento:

a) existência de pixels sem coloração. Neste caso o interpolador não calculou o valor de altitude de alguns pixels. Nestes locais, os pixels apresentam cor branca (Figura 53).

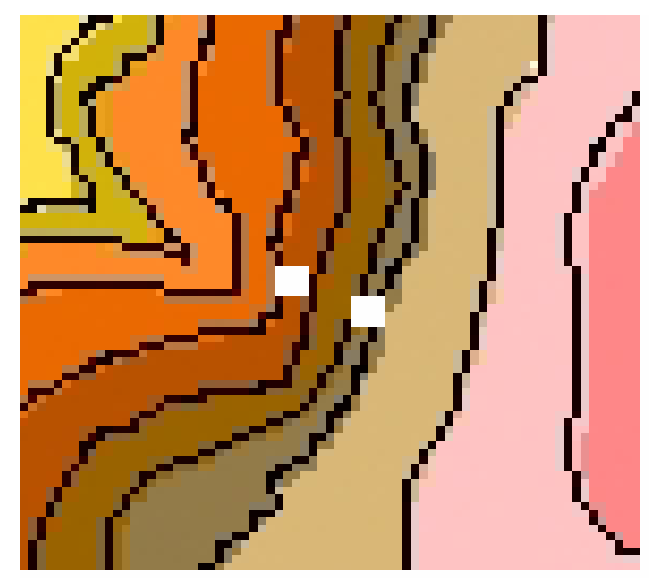

Figura 53 - Pixels sem coloração

b) distribuição das fatias de cores não seguindo a distribuição das curvas de nível (Figura 54).

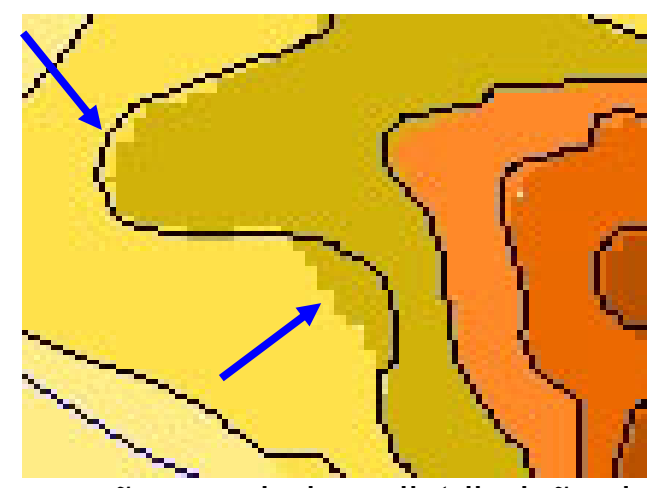

Figura 54 - Fatias de cores não seguindo a distribuição das curvas de nível. 


\subsubsection{Segunda metodologia, criação do mapa de fatiamento pelo software AutoCAD.}

Com o objetivo de produzir o mapa de fatiamento, utilizou-se a ferramenta "Hachura", do software AutoCAD, para "pintar" os intervalos das curvas de nível. Dessa forma, foi criado um mapa de fatiamento sem a necessidade de utilizar interpoladores para a geração de um MNT (Figura 55).

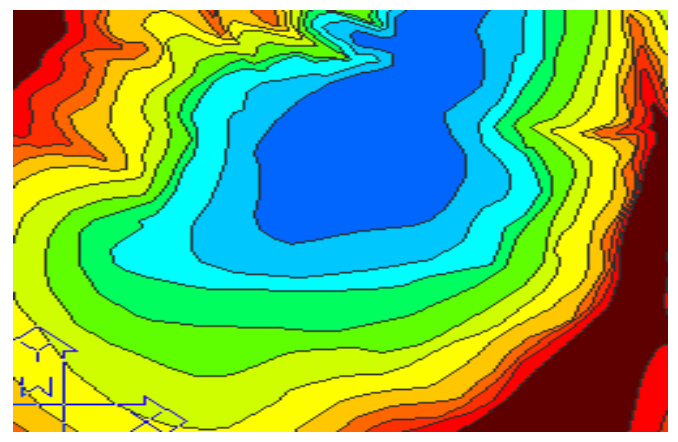

Figura 55 - Parte do mapa de fatiamento produzido pelo software AutoCAD

Como a distribuição das cores no mapa de fatiamento, produzido pelo software AutoCAD, não apresentou problemas semelhantes ao método anterior e sempre seguiu a distribuição das curvas de nível digitalizadas, adotou-se o presente método como o mais viável para geração de mapas de fatiamento deste projeto.

O referido mapa foi georreferenciado pelo software I e utilizado como fonte de informação pelo software II, para criação do banco de dados de atributos altimétricos. 


\subsection{Resultados da Análise Estatística e do Padrão de Exatidão Cartográfica.}

\subsubsection{Resultados}

Foi comparado os dados de pontos de análise (PA), obtidos pelo software III, calculado para as coordenadas $\mathrm{E}$ e $\mathrm{N}$ dos pontos de controle de referência (PCR), levantados na carta topográfica. A Figura 56 apresenta a distribuição dos PCR na carta topográfica.

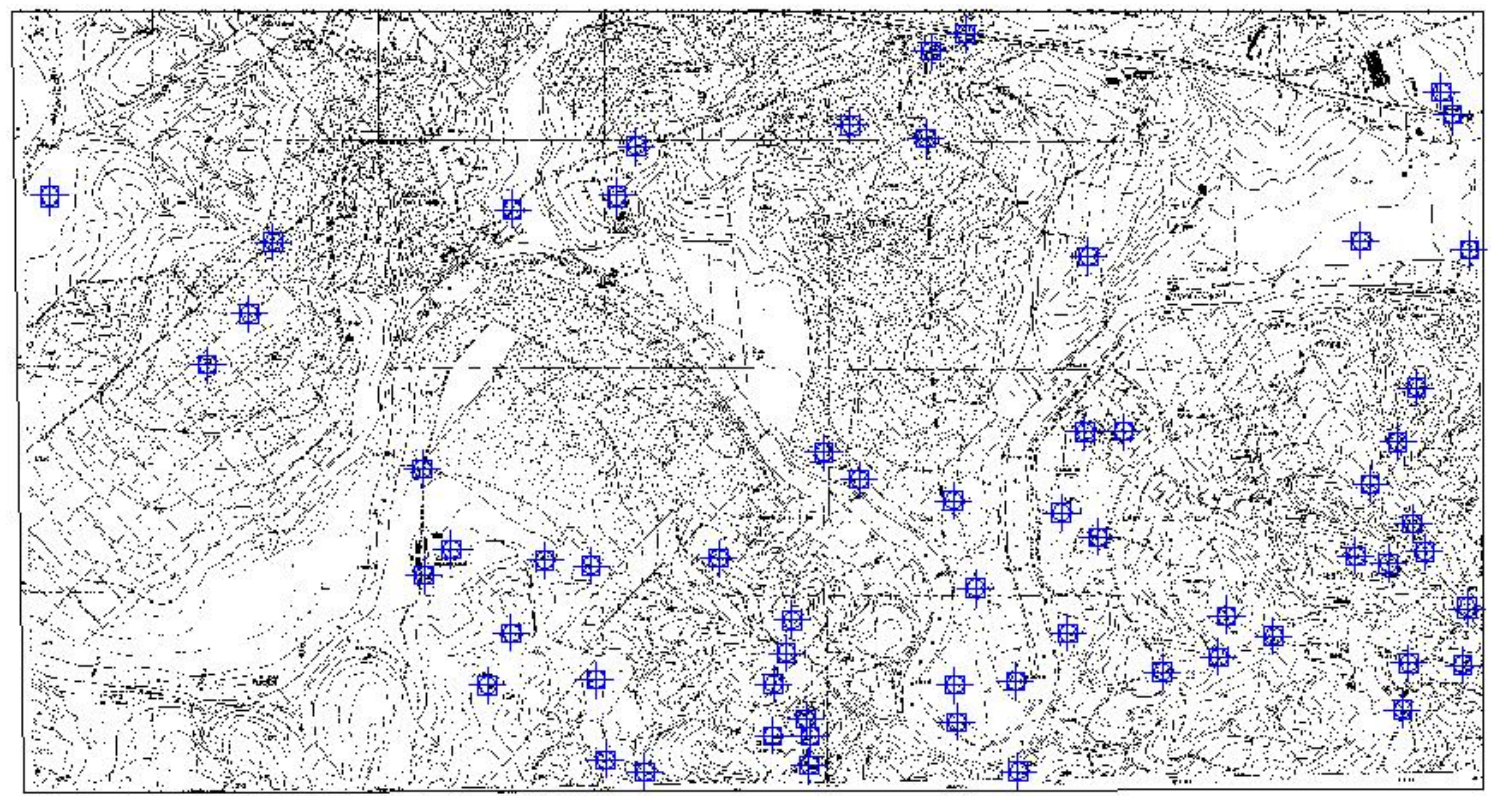

Figura 56 - Distribuição dos pontos de controle de análise na carta topográfica

A Tabela 1 demonstra a altitude (Z) dos PCR e dos PA com as suas respectivas coordenadas UTM.

Tabela 1. Coordenadas de PA e PCR

\begin{tabular}{cccccc}
\hline Pontos & \multicolumn{2}{c}{ Coordenadas UTM $(m)$} & \multicolumn{2}{c}{ Altitude $(\mathrm{Z})$} & Erro $(\mathrm{m})$ \\
& $\mathrm{E}$ & $\mathrm{N}$ & $\mathrm{PCR}(\mathrm{m})$ & $\mathrm{PA}(\mathrm{m})$ & \\
\hline 1 & $217.549,42$ & $7.488 .752,19$ & 458 & 456,90 & 1,10 \\
2 & $218.537,64$ & $7.488 .552,98$ & 514 & 512,12 & 1,88
\end{tabular}


Tabela 1. Coordenadas de PA e PCR

\begin{tabular}{|c|c|c|c|c|c|}
\hline \multirow[t]{2}{*}{ Pontos } & \multicolumn{2}{|c|}{ Coordenadas UTM $(\mathrm{m})$} & \multicolumn{2}{|c|}{ Altitude(Z) } & \multirow[t]{2}{*}{ Erro $(m)$} \\
\hline & $E$ & $\mathrm{~N}$ & $\operatorname{PCR}(\mathrm{m})$ & $\mathrm{PA}(\mathrm{m})$ & \\
\hline 3 & $218.431,06$ & $7.488 .237,26$ & 513 & 513,53 & $-0,53$ \\
\hline 4 & $218.248,39$ & $7.488 .010,45$ & 512 & 511,31 & 0,69 \\
\hline 5 & $219.200,60$ & $7.487 .549,35$ & 459 & 457,32 & 1,68 \\
\hline 6 & $219.326,39$ & $7.487 .192,88$ & 464 & 461,23 & 2,77 \\
\hline 7 & $219.208,46$ & 7.487.078,93 & 468 & 466,07 & 1,93 \\
\hline 8 & $219.742,94$ & $7.487 .143,50$ & 463 & 463,29 & $-0,29$ \\
\hline 9 & $219.592,71$ & $7.486 .829,02$ & 499 & 497,94 & 1,06 \\
\hline 10 & $219.488,60$ & $7.486 .597,97$ & 504 & 503,12 & 0,88 \\
\hline 11 & $219.948,37$ & $7.487 .118,81$ & 468 & 466,64 & 1,36 \\
\hline 12 & $219.967,92$ & $7.486 .622,66$ & 468 & 467,61 & 0,39 \\
\hline 13 & $220.012,00$ & $7.486 .267,62$ & 469 & 469,07 & $-0,07$ \\
\hline 14 & $220.512,80$ & $7.487 .153,43$ & 506 & 508,68 & $-2,68$ \\
\hline 15 & $220.843,71$ & $7.486 .885,95$ & 517 & 518,57 & $-1,57$ \\
\hline 16 & $220.820,89$ & $7.486 .739,71$ & 514 & 513,02 & 0,98 \\
\hline 17 & $220.763,83$ & $7.486 .602,97$ & 516 & 518,26 & $-2,26$ \\
\hline 18 & $220.760,14$ & 7.486.374,18 & 508 & 507,24 & 0,76 \\
\hline 19 & $220.906,59$ & $7.486 .448,25$ & 514 & 513,31 & 0,69 \\
\hline 20 & $220.925,62$ & $7.486 .372,28$ & 509 & 507,88 & 1,12 \\
\hline 21 & $220.919,91$ & $7.486 .243,14$ & 511 & 512,00 & $-1,00$ \\
\hline 22 & $219.598,53$ & $7.488 .695,55$ & 462 & 461,50 & 0,50 \\
\hline 23 & $220.061,92$ & $7.488 .752,86$ & 502 & 503,64 & $-1,64$ \\
\hline 24 & $220.147,52$ & 7.488.971,26 & 507 & 508,56 & $-1,56$ \\
\hline 25 & $221.101,77$ & $7.489 .063,77$ & 538 & 536,10 & 1,90 \\
\hline 26 & $221.461,25$ & 7.489.392,60 & 539 & 537,21 & 1,79 \\
\hline 27 & $221.613,42$ & $7.489 .468,57$ & 538 & 539,46 & $-1,46$ \\
\hline 28 & $221.438,44$ & $7.489 .006,80$ & 536 & 537,91 & $-1,91$ \\
\hline 29 & $222.157,74$ & $7.488 .489,95$ & 502 & 501,84 & 0,16 \\
\hline 30 & $220.986,42$ & 7.487.621,46 & 463 & 461,67 & 1,33 \\
\hline 31 & $221.141,65$ & $7.487 .503,08$ & 469 & 469,09 & $-0,09$ \\
\hline 32 & $221.560,20$ & $7.487 .407,28$ & 473 & 473,36 & $-0,36$ \\
\hline 33 & $222.143,08$ & $7.487 .713,37$ & 463 & 462,06 & 0,94 \\
\hline 34 & $222.037,97$ & $7.487 .354,14$ & 464 & 461,79 & 2,21 \\
\hline
\end{tabular}


Tabela 1. Coordenadas de PA e PCR

\begin{tabular}{cccccc}
\hline Pontos & Coordenadas UTM $(m)$ & \multicolumn{2}{c}{ Altitude $(Z)$} & Erro $(m)$ \\
& $\mathrm{E}$ & $\mathrm{N}$ & $\mathrm{PCR}(\mathrm{m})$ & $\mathrm{PA}(\mathrm{m})$ & \\
\hline 35 & $221.659,11$ & $7.487 .021,75$ & 468 & 466,94 & 1,06 \\
36 & $222.065,43$ & $7.486 .829,14$ & 464 & 462,33 & 1,67 \\
37 & $221.834,20$ & $7.486 .617,41$ & 466 & 467,91 & $-1,91$ \\
38 & $221.566,01$ & $7.486 .600,32$ & 468 & 466,53 & 1,47 \\
39 & $222.198,37$ & $7.487 .246,79$ & 468 & 468,16 & $-0,16$ \\
40 & $222.312,50$ & $7.487 .715,21$ & 467 & 467,67 & $-0,67$ \\
41 & $222.486,15$ & $7.486 .657,21$ & 508 & 506,30 & 1,70 \\
42 & $222.769,20$ & $7.486 .905,11$ & 516 & 518,33 & $-2,33$ \\
43 & $222.733,11$ & $7.486 .723,96$ & 503 & 502,07 & 0,93 \\
44 & $222.976,67$ & $7.486 .815,12$ & 506 & 508,87 & $-2,87$ \\
45 & $221.575,21$ & $7.486 .434,66$ & 463 & 462,19 & 0,81 \\
46 & $223.721,20$ & $7.489 .212,20$ & 464 & 465,95 & $-1,95$ \\
47 & $223.769,28$ & $7.489 .111,03$ & 467 & 465,45 & 1,55 \\
48 & $223.362,75$ & $7.488 .558,82$ & 463 & 463,26 & $-0,26$ \\
49 & $223.528,74$ & $7.487 .668,54$ & 519 & 516,88 & 2,12 \\
50 & $223.406,78$ & $7.487 .481,50$ & 534 & 531,92 & 2,08 \\
51 & $223.592,33$ & $7.487 .306,40$ & 527 & 528,06 & $-1,06$ \\
52 & $223.648,19$ & $7.487 .181,81$ & 534 & 531,39 & 2,61 \\
53 & $223.340,63$ & $7.487 .163,34$ & 530 & 527,07 & 2,93 \\
54 & $223.486,32$ & $7.487 .129,53$ & 523 & 523,50 & $-0,50$ \\
55 & $223.835,18$ & $7.486 .937,76$ & 533 & 533,64 & $-0,64$ \\
56 & $223.575,62$ & $7.486 .697,65$ & 527 & 527,16 & $-0,16$ \\
57 & $223.549,37$ & $7.486 .490,10$ & 521 & 520,62 & 0,38 \\
\hline
\end{tabular}

A Tabela 2 demonstra os resultados estatísticos da regressão linear, obtidos para PA em comparação aos PCR.

Tabela 2. Resultados estatísticos para os pontos de análise

\begin{tabular}{rrrr}
\hline & Fator de Significância & Coeficiente para a variável X & $\begin{array}{r}\text { Coeficiente de } \\
\text { determinação }\left(R^{2}\right)\end{array}$ \\
\hline Resultados & $6,2512 \mathrm{E}-72$ & 1,01 & 0,9972
\end{tabular}


A Figura 57 representa o comportamento da linha de tendência no diagrama de dispersão dos dados analisados.

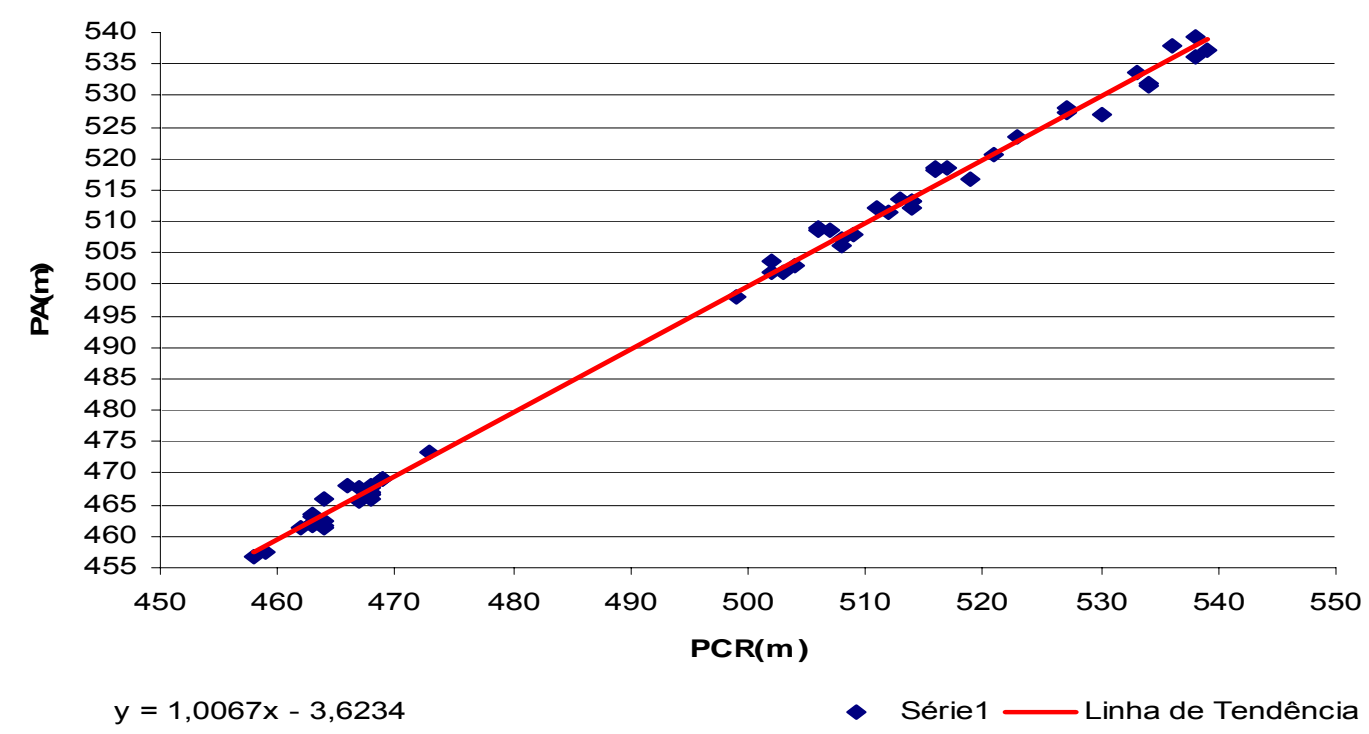

Figura 57 - Diagrama de dispersão dos dados analisados

Para analisar a qualidade do produto gerado, segundo as normas legais de cartografia existentes no Brasil, adotou-se o Decreto n 89.817 de 20 de Junho de 1984, o qual na seção 1, Art. 8, Item 2.1 e 2.2 estabelece as especificações de qualidade utilizando o padrão de exatidão cartográfica (PEC) e o erro padrão.

Porcentagem de pontos de testes que verificam o PEC: $91,23 \%$

Erro padrão: $1,48 m$

\subsubsection{Discussão}

Para a discussão dos resultados apresentados anteriormente foram considerados critérios estatísticos e normas de qualidade da Cartografia Nacional.

$\mathrm{Na}$ análise estatística adotou-se um nível de significância de 0,01 (1\%) e verificarou-se os resultados de regressão linear que constam na Tabela 2. 
Observou-se que o Fator de significância se comportou sempre menor que 0,01 para o método analisado, onde conclui-se que a regressão para os resultados obtidos é valida.

Observou-se também o Coeficiente de Determinação $\left(R^{2}\right)$ permaneceu próximo ao valor 1 , significando que a relação entre as medidas da carta e as medidas da imagem é linear.

Por outro lado o coeficiente angular da reta de ajuste (coeficiente de correlação) apresentou valor de 1,007. Correspondendo a um ângulo de inclinação de $45^{\circ}$ da reta de ajuste. Indicando uma forte correlação entre as medidas da carta e da imagem. Este comportamento foi reafirmado na análise gráfica (Figura 57), onde criou-se uma linha de tendência no gráfico de dispersão.

Para quantificar a exatidão dos resultados, adotou-se as Normas Técnicas da Cartografia Nacional. Considerou-se um padrão de exatidão cartográfica de Classe A, portanto, noventa por cento dos pontos analisados não deverão apresentar erro superior a $2,5 \mathrm{~m}$ neste projeto, sendo que, o erro padrão não poderá ultrapassar $1,67 \mathrm{~m}$. Segundo o capítulo 3.2 .5 , verificou-se que somente cinco pontos apresentaram erros de altitude superiores a $2,5 \mathrm{~m}$ (Tabela 3). Porém, $91,23 \%$ dos dados de testes, estiveram abaixo de 2,5m. 0 erro padrão apresentou-se menor do que $1,67 \mathrm{~m}(1,48 \mathrm{~m})$, onde concluiu-se que os resultados obtidos pelo Software III se adequaram ao Padrão de Exatidão Cartográfica (PEC).

Tabela 3. Tabela de erros de altitude superiores a $2,5 \mathrm{~m}$

\begin{tabular}{cccccc}
\hline Ponto & \multicolumn{2}{c}{ Coordenadas UTM $(m)$} & \multicolumn{2}{c}{ Altitude $(\mathrm{Z})$} & Erro $(\mathrm{m})$ \\
& $\mathrm{E}$ & $\mathrm{N}$ & $\mathrm{PCR}(\mathrm{m})$ & $\mathrm{PA}(\mathrm{m})$ & \\
\hline 6 & $219.326,39$ & $7.487 .192,88$ & 464 & 461,23 & 2,77 \\
14 & $220.512,80$ & $7.487 .153,43$ & 506 & 508,68 & $-2,68$ \\
44 & $222.976,67$ & $7.486 .815,12$ & 506 & 508,87 & $-2,87$ \\
52 & $223.648,19$ & $7.487 .181,81$ & 534 & 531,39 & 2,61 \\
53 & $223.340,63$ & $7.487 .163,34$ & 530 & 527,07 & 2,93 \\
\hline
\end{tabular}




\section{CONCLUSÕES}

Como resultado das discussões realizadas, chegou-se as seguintes conclusões:

1) Os testes estatísticos realizados e a verificação das normas de exatidão cartográfica mostram a boa qualidade métrica dos resultados obtidos.

2) O produto digital resultante da metodologia pesquisada mostrou-se amigável e de fácil uso, verificando uma das condições originais do projeto.

3) O custo tempo/trabalho de elaboração do produto final com a metodologia proposta, resulta economicamente competitivo com o uso de softwares do tipo SIG existentes no mercado. 


\section{REFERÊNCIAS BIBLIOGRÁFICAS}

ANAND, V.B. Computer graphics and geometric modeling for engineers. Singapore: John-Wiley, 1993. 364p.

ASSAD, E.D.; SANO, E.E. Sistema de informações geográficas: aplicações na agricultura. Brasília: EMBRAPA, CPAC, 1993. 274p.

AZEVEDO, E.; CONCl, A. Computação gráfica: teoria e prática. Rio de Janeiro: Elsevier, 2003. 353p.

BACELLAR, A.A.A. Estudo da erosão na microbacia hidrográfica do Ribeirão Cachoeirinha. Iracemápolis: UNICAMP, 1994. 30p. (Relatório Técnico).

BALASTREIRE, L.A. Estudo de caso, uma pesquisa brasileira em agricultura de precisão. In: SILVA, F.M; BORGES, P.H. DE M. Mecanização e agricultura de precisão. Lavras: UFLA;SBEA, 1998. p. 231-302.

CABRERA, F.R. Geotecnologia na agricultura de precisão. Campo Grande, 2001. 56p. Monografia (Graduação) - Universidade para o Desenvolvimento do Estado e da Região do Pantanal. 
CÂMARA, N.G; CASANOVA, M.A; HEMERLY, A.S; MAGALHÃES, G.C; MEDEIROS, C.M.B. Anatomia de sistemas de informações geográfica. IV Escola de computação Campinas: UNICAMP, 1996.193p.

CARVER, S.; HEYWOOD, L.; COENELLIUS, S.; SEAR, D. Evaluating fieldbased GIS for environmental characterization, modelling and decision pupport. International Journal of Geographical Information Systems, v.9, p. 475-486, 1995.

CINTRA, J.P.; NERO, M.A. Digitalização de mapas: estudo comparativo de metodologias. www.gisbrasil.com.br/anais/2001/1299.zip (04 mar. 2001).

COSTA, F.A.L. Geração de coordenadas tridimensionais do terreno a partir de imagens fotogramétricas digitais. /Apresentado ao 8. Simpósio Internacional de Iniciação Científica da Universidade de São Paulo, São Paulo, 2000/

CHARNET, R.; FREIRE, C.A.L.; CHARNET, E.M.R.; BONVINO, H. Análise de modelos de regressão linear com aplicações. Campinas: UNICAMP, 1999. 357p.

CRÓSTA, A. P. Processamento digital de imagens de sensoriamento remoto. Campinas: UNICAMP, 1992. 170p.

DELMIRO, M.A.T. Mosaico de imagens para sistemas de informações geográficas. In: SEMANA ESTADUAL DE GEOPROCESSAMENTO. Rio de Janeiro, 1996. Geoprocessamento: Mito \& Realidade. Rio de Janeiro: Campus, 1996. p.25. 
FARRET, J.C. Aplicabilidade de georreferenciamento de aerofotos de pequeno formato na formação de bancos de dados espaciais - uma alternativa para o cadastro técnico rural municipal. Santa Maria, 1996. 111p. Dissertação (Mestrado) - Universidade Federal de Santa Maria.

FARRET, J.C.; GIOTTO, E. Aplicabilidade do georreferenciamento de aerofotos de pequeno formato na formação de bancos de dados espaciais - uma alternativa para o cadastro técnico rural municipal. Ciência Rural, v.27, n.4, p.577-581, abr. 1997.

FURTADO, A.L. Organização de banco de dados. 6.ed. Rio de Janeiro: Campus, 1986. 121p.

GHOSH, S.K. Analytical photogrammetry. Oxford: Pergamon Press, 1988. $320 p$.

HOFFMANN, R.; VIEIRA, S. Estatística experimental. São Paulo: Atlas, 1989. $179 p$.

INSTITUTO NACIONAL DE PESQUISAS ESPACIAIS. Tutorial do software spring. São José dos Campos: INPE, 2001. 247p.

AMERICAN SOCIETY OF PHOTOGRAMMETRY. Manual de photogrammetry. 4.ed. Virginia, 1980. 210p.

MARCOS, A. Color: a tool for computer graphics communication. Computer Graphics, v.10, p.180-188, July 1987.

MARTINS, G.A. Estatística geral e aplicada. 2.ed. São Paulo: Atlas, 2002. $417 p$. 
MINGHIN, R. Modelagem de objetos por splines. Campinas, 1980. 127p. Dissertação (Mestrado) - Instituto Militar de Engenharia.

MOLIN, J.P. Geração interpretação de mapas de produtividade para agricultura de precisão. In: BORÉM, A.; GIÚDICE, M.P. del; QUIROZ, D.M. de; MANTOVANI, E.C.; FERREIRA, L.R.; VALLE, F.X.R. do; GOMIDE, R.L. Agricultura de precisão. Viçosa: Universidade Federal de Viçosa, 2000. p. 237-258.

MOLIN, J.P. Agricultura de precisão: o gerenciamento da variabilidade. Piracicaba: o autor, 2001. 83p.

MORAES, J.F.L.; NEGREIROS, S.R.; VIEIRA, P.M. Digital elevation modeling and relief attributes obtained thorough DGPS survey and interpolation analysis. In: EUROPEAN CONFERENCE ON PRECISION AGRICULTURE, 3., Montpellier, 2001. Proceedings. Montpellier: BIOS Scientific Publishers, 2001. 6p.

MOREIRA, M.A. Fundamentos do sensoriamento remoto e metodologias de aplicação. São José dos Campos: INPE, 2001. 250p.

NELSON, R. Visual basic for windows versão 3.0. 2. ed. São Paulo: Makron, 1994. 390p.

NOVO, E.M.L. Sensoriamento remoto: princípios e aplicações. 2.ed. São José dos Campos: Edgard Blücher, 1993, 297p.

OLIVEIRA, C. Curso de cartografia moderna. Rio de Janeiro: IBGE, 1988. $152 p$. 
PARISE, F.J.O. Análise temporal de uso da terra em uma microbacia hidrográfica no município de Piracicaba, SP, por meio de técnicas de geoprocessamento. Piracicaba, 1999. 114p. Dissertação (Mestrado) Escola Superior de Agricultura "Luiz de Queiroz", Universidade de São Paulo.

PECCOL, E.; BIRD, C.A.; BREWER, T.R. Geographic information systems (GIS) and landscape mapping. In: C.I.G.R. WORLD CONGRESS AND AGENG'94 CONFERENCE ON AGRICULTURAL ENGINEERING, Milan, 1994. Anais. Milan: Interprint Ltd, 1994. p.59-67.

PECZE, Z.; NEMÉNYI, M.; KISS, E.; PETRÓCZKI, F. Investigation of the accuracy of the RDS yield mapping system. In: EUROPEAN CONFERENCE ON PRECISION AGRICULTURE, 2., Denmark, 1999. Programme abstracts (poster session 2) list of exhibitors. Denmark: BIOS Scientific Publishers, 1999. p. 50.

PETRIE, G.; KENNIE, T.J.M. Terrain modeling in surveying photogrammetry. Caithness: Whittles, 1990. 102p.

PETTINATI, F. Modelagem digital e representação gráfica de superfícies. São Paulo, 1983. 197p. Dissertação (Mestrado) - Escola Politécnica, Universidade de São Paulo.

QUINTANILHA, J.A. Erros em bases digitais de dados espaciais para uso em sistemas de informação geográfica. São Paulo, 1996. 236p. Tese (Doutorado) - Escola Politécnica, Universidade de São Paulo. 
RAFFO, J.G.G.R. Retificação virtual de fotografias de pequeno formato e sua aplicação para vôos aerofotográficos. São Paulo, 2000. 192p. Tese (Doutorado) - Faculdade de Filosofia, Letras e Ciências Humanas, Universidade de São Paulo.

ROCHA, J.V. Geoprocessamento e agricultura de precisão. Campinas: Agropecuária, 2001. 120p.

SAMESHIMA, R.H.; YAMAMOTO, J.K. Análise de malhas de amostragens e processos de interpolação na representação de superfícies topográficas por meio de MDTs. Geociências, v.15, n.1, p.67-92, 1996.

SCARIM, J.; TEIXEIRA, A.L.A. Digitalização e conversão raster/vetor de mapas. Fator GIS, v.2, n.6, p.6-21, 1994.

SHIRMOHAMMADI, A.; MAGETTE, W.L.; BEKDASH, F.A. Environmental evaluation of agricultural practices using modelling and GIS technologies. In: C.I.G.R. WORLD CONGRESS AND AGENG'94 CONFERENCE ON AGRICULTURAL ENGINEERING, Milan, 1994. Anais. Milan: Interprint Ltd, 1994. p.69-78.

STAR, J.; ESTES, J. Geographic Information Systems: introduction. New Jersey: Prentice-Hall, 1990. 303p.

STEINMETZ, S.; REYNIERS, F. N.; FOREST, F. Evaluation of the climatic risk on upland rice in Brazil. In: COLLOQUE RESISTENCE A LA SECHERESSE EN MILLIEU INTERTROPICALE: QUELLES RECHERCHES POUR LE MOYEN TERME?, Dakar, 1984. Proceedings. Paris: CIRAD, 1985. p.4354. 
VANNI, S.M. Modelos de regressão linear e não linear simples. São Paulo: Legnar Informática \& Editora, 1998. 177p.

VUOLO, J. H. Fundamentos da teoria de erros. São Paulo: Edgard Blücher, 1992. 225p.

WOLF, P.R. Elements of photogrammetry. New York: McGraw-Hill book, 1983. 628p. 